\title{
The Prospective Non-Conventional Alternate and Renewable Energy Sources in Pakistan-A Focus on Biomass Energy for Power Generation, Transportation, and Industrial Fuel
}

\author{
Wajahat Ullah Khan Tareen ${ }^{1,2, *}$, Zuha Anjum ${ }^{1}$, Nabila Yasin ${ }^{1}$, Leenah Siddiqui ${ }^{1}$, \\ Ifzana Farhat ${ }^{1}$, Suheel Abdullah Malik ${ }^{1}$, Saad Mekhilef ${ }^{2} \mathbb{1}$, Mehdi Seyedmahmoudian ${ }^{3}$, \\ Ben Horan ${ }^{4}\left(\mathbb{D}\right.$, Mohamed Darwish ${ }^{5}$, Muhammad Aamir ${ }^{6}$ and Leong Wen Chek ${ }^{2}$ \\ 1 Department of Electrical Engineering, International Islamic University, Islamabad 44000, Pakistan; \\ zuha.anjum95@gmail.com (Z.A.); engineernabilayasinjutt@gmail.com (N.Y.); \\ leenah.mubeen@gmail.com (L.S.); ifzanafarhat2013@gmail.com (I.F.); suheel.abdullah@iiu.edu.pk (S.A.M.) \\ 2 Power Electronics and Renewable Energy Research Laboratory (PEARL), Department of Electrical \\ Engineering, University of Malaya, Kuala Lumpur 50603, Malaysia; saad@um.edu.my (S.M.); \\ leong@um.edu.my (L.W.C.) \\ 3 School of Software and Electrical Engineering, Swinburne University of Technology, Melbourne, VIC 3122, \\ Australia; mseyedmahmoudian@swin.edu.au \\ 4 School of Engineering, Deakin University, Waurn Ponds, VIC 3216, Australia; ben.horan@deakin.edu.au \\ 5 Electronic and Computer Engineering, Brunel University London, Uxbridge UB8 3PH, UK; \\ mohamed.darwish@brunel.ac.uk \\ 6 Department of Electrical Engineering, Bahria University, Islamabad 44000, Pakistan; \\ muhammadaamir.buic@bahria.edu.pk \\ * Correspondence: wajahat.tareen@iiu.edu.pk; Tel.: +92-332-574-4848
}

Received: 19 August 2018; Accepted: 5 September 2018; Published: 13 September 2018

\begin{abstract}
Pakistan is experiencing an undersupply of electricity, causing load shedding several hours per day due to the adherence to conventional energy resources having quantitative and environmental limitations. Fossil fuels generate more than half of the country's total electricity, but they will ultimately run out due to their limited supply. Their combustion emits greenhouse gases, posing environmental threats. Since the world is tending toward efficient and sustainable alternative methods for harvesting energy from nature, Pakistan has also been investigating an elevated deployment of renewable energy projects. This paper presents a critical analysis of the present energy sector of Pakistan along with global scenarios. Pakistan relies on mainly thermal, hydro, and nuclear energy for power generation. National solar, wind, geothermal, and biomass resources have not been extensively explored and implemented. This paper provides an insight into the potential of these resources in Pakistan to generate electricity for the national grid on a large scale. It focuses on biomass energy, which can be harnessed from bagasse, poultry waste, and municipal waste for power production, and biomass-based fuel for industries and transportation. It concludes that biomass is the most sustainable, available, implementable, and environment-friendly resource that can be utilized to lessen the energy demand and supply gap in Pakistan.
\end{abstract}

Keywords: electricity generation; energy crisis; renewable energy sources; transportation; biomass energy; biofuels 


\section{Introduction}

A country's human and socioeconomic progress is broadly dependent on its energy potential, which can be expressed simply in terms of its energy contribution per capita [1]. There has been a significant growth in the global population and a rise in living standards that account for a raised demand of power and energy, especially in the developing countries [2]. As the energy demand is rising, the energy prices have also been increasing, which along with the recent geopolitical events, has drawn the world's attention toward the vital role played by affordable and sustainable energy in economic growth and human development [3].

Figure 1 shows an increase in the energy resources demand up to the year 2030. It can be observed that even though the energy demand using coal, oil, and gas has significantly increased, there will be a substantial rise in the use of renewable energy sources. In 2007, the world electrical energy production was 16,429 Terawatt-hour (TWh), and its projected consumption in 2030 is 28,930 TWh i.e., a $49 \%$ increase in the global energy demand and $87 \%$ rise in world electricity generation is expected $[4,5]$.

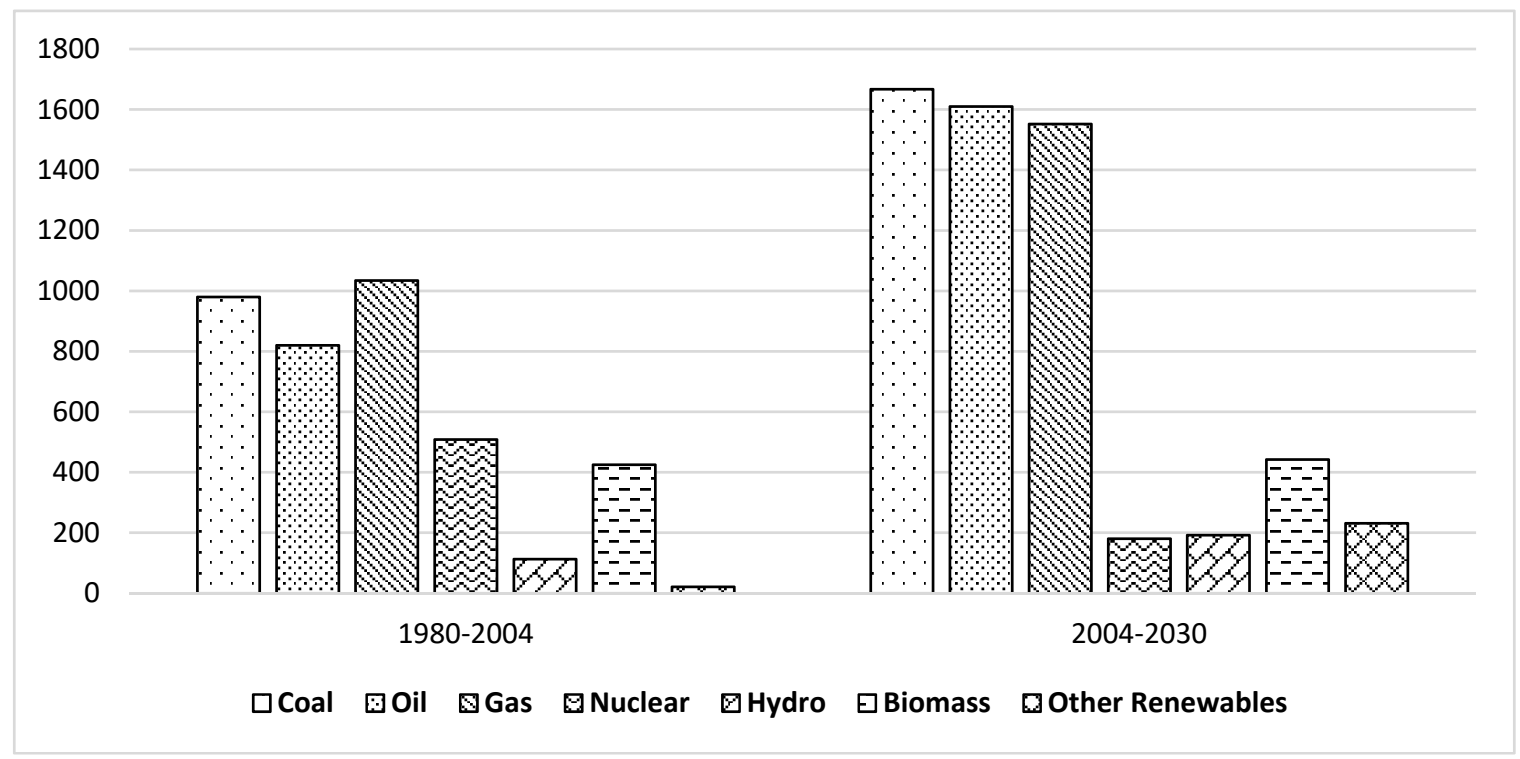

Figure 1. Increase in demand of energy resources.

The International Energy Agency (IEA) reports the improvement of the overall provision of energy from primary sources to 12,717 million tons of oil equivalent (mtoe) in 2010, which was up from 6107 MTOE in 1973, and includes oil, coal, natural gas, biofuels, nuclear, hydro, and various other resources with contributions of $32.4 \%, 27.3 \%, 21.4 \%, 10 \%, 5.7 \%, 2.3 \%$, and $0.9 \%$, respectively [6]. Group of Eight (G8) leaders met the heads of major developing countries and international organizations in 2005 and 2006, to work together with the IEA regarding clean and prosperous alternate scenarios of obtaining energy in future [3].

Figure 2 shows the projected electricity demand and supply from 2016 to 2020. It is expected that by 2020, the world will be able to bridge the energy and supply gap, and will also have a surplus power of 3491 megawatts (MW). Rapid decline in the worldwide fossil fuel resources and their impulsively instable costs have posed damage to the world's economy. The climate of the planet is affected by their abuse, causing an amplified degree of pollution, damage to the ozone layer, and extraordinary variations in the earth's climate. The inimitability of fossil fuels in the current energy scenario and their value to future generations is also certain [7]. Table 1 shows the energy situation using renewable resources by 2040. The European Renewable Energy Council (EREC) projected in 2006 that by 2040, $50 \%$ of the world's energy will come from renewables [8]. 


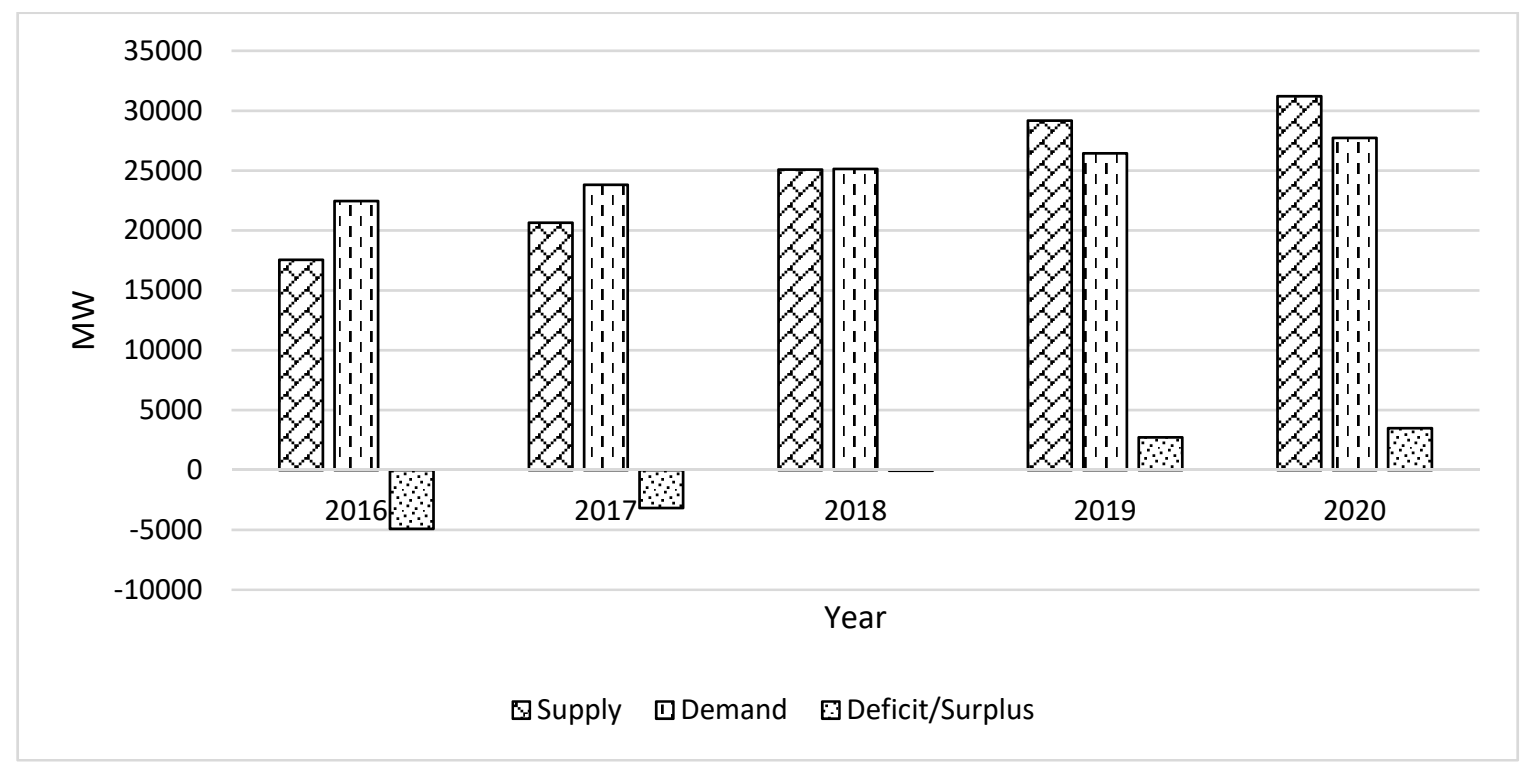

Figure 2. Projected electricity demand and supply for 2016-2020.

Pakistan ranks sixth in the world's most populous countries with 173.51 million people, and by 2050 , it is predicted to be number four. At present, Pakistan has daunting problems regarding inadequate installed capacity, revenue shortage, and circular debt for energy production [9]. The energy sector majorly relies on conventional resources such as coal, oil, and natural gas. Due to increase in their demand, the country is facing a shortfall of these natural resources. Their use releases greenhouse gases, rendering them unfit for the environment. The deviations caused by man's actions in nature and the nature's response to these actions have greatly affected the environment of our planet in the last decades $[10,11]$. People around the globe are becoming aware of the finiteness of the natural resources and the threat to future generations due to their non-conservation [12]. The oil reserves of the world are located in regions of political and ethnic conflicts that are challenging to solve in a short time span [13]. Also, the fluctuation in furnace oil prices and the per-unit cost of electricity, along with the inflation rate, have adversely pressurized the national economy [14].

Table 1. Global renewable energy scenario for 2040.

\begin{tabular}{cccccc}
\hline Sources Category & $\mathbf{2 0 0 1}$ & $\mathbf{2 0 1 0}$ & $\mathbf{2 0 2 0}$ & $\mathbf{2 0 3 0}$ & $\mathbf{2 0 4 0}$ \\
\hline Total consumption (mtoe) & 10,038 & 10,549 & 11,425 & 12,352 & 13,310 \\
Biomass & 1080 & 1313 & 1791 & 2483 & 3271 \\
Large hydro & 22.7 & 266 & 309 & 341 & 358 \\
Geothermal & 43.2 & 86 & 186 & 333 & 493 \\
Small hydro & 9.5 & 19 & 49 & 106 & 189 \\
Wind & 4.7 & 44 & 266 & 542 & 688 \\
Solar thermal & 4.1 & 15 & 66 & 244 & 480 \\
Photovoltaic & 0.2 & 2 & 24 & 221 & 784 \\
Solar thermal electricity & 0.1 & 0.4 & 3 & 16 & 68 \\
Marine (tidal/wave/ocean) & 0.05 & 0.1 & 0.4 & 3 & 20 \\
Total renewable energy sources & 1365.5 & 1745.5 & 2694.4 & 4289 & 6351 \\
Renewable energy sources contribution (\%) & 13.6 & 16.6 & 23.6 & 34.7 & 47.7 \\
\hline
\end{tabular}

The rift of 5201 MW (range 3000-6000 MW) in the demand and supply of power and energy, as of 2015 , caused a daily power cut of $14-18 \mathrm{~h}$. Even after some progress in the energy sector, the country still faces some deficit. The use of renewable energy resources will not only put an end to the deficit, but surplus energy will be available in coming years, as predicted in Figure 2 [15]. So, it is necessary to adopt renewable resources, considering their superabundance, sustainability, native availability, and environment safety [16]. Earth has a plentiful amount of the resources that are needed for the successful development of solar, hydraulic, wind, geothermal, and biomass-based projects, 
enabling a diversity in the country's energy mix [17]. Pakistan's current energy fuel mix based on installed capacity is shown in Figure 3. As of 2017, depending upon the sources, the fuel mix is divided into two categories, i.e., carbon-based and carbon-free, in which $65 \%$ of the current fuel mix is carbon-based, while $35 \%$ is carbon-free. Renewable energy has a share of only $3 \%$. Natural gas has a share of $41 \%$ in the fuel mix and 10,332 MW capacity and oil has a share of $24 \%$ with 6137 MW capacity; these are the carbon-based fuels. Hydro energy has a share of $28 \%$ in the fuel mix and $7116 \mathrm{MW}$ capacity, nuclear has a share of 3\% with $787 \mathrm{MW}$ capacity, and renewables have a share of $3 \%$ with 852 MW capacity; these are the carbon-free fuels. The vision by 2025 is to decrease the percentage of carbon-based fuels to $62 \%$, so that the usage of clean energy sources may rise to $38 \%$ such that hydro, nuclear and renewable energy sources will have $27 \%, 7 \%$, and $5 \%$ shares in the fuel mix and 13,142 MW, 3667 MW, and 2339 MW capacities, respectively [8,18].

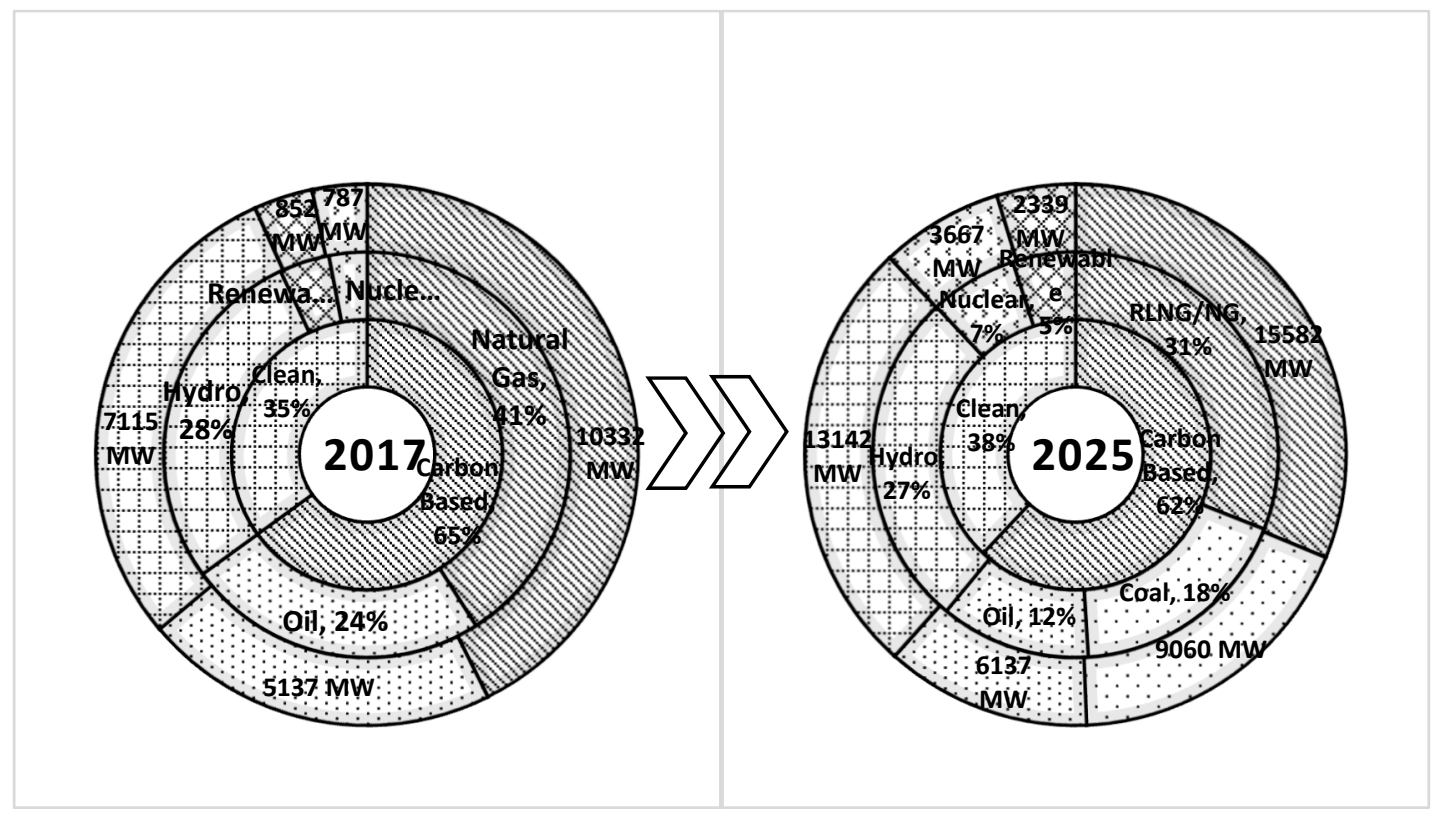

Figure 3. Pakistan's energy fuel mix (2017-2025).

Wind energy serves as a renewable clean energy source with a vast capacity of 346 gigawatts (GW). Pakistan has $120 \mathrm{GW}$ viable, particularly in the coastal lines of Sindh and Balochistan provinces, the velocity of wind being $4-9 \mathrm{~ms}^{-1}$ and $12.5 \mathrm{~ms}^{-1}$ at $10 \mathrm{~m}$ and $50 \mathrm{~m}$ height, respectively [15].

Pakistan has 300 sun shining days because of its geolocation, creating a mean temperature per annum of $26-28{ }^{\circ} \mathrm{C}$ and $1900-2200 \mathrm{kWh} / \mathrm{m}^{3}$ per annum global radiation, providing a solar potential of 2,900,000 MW. In total, 18 photovoltaic systems with $440 \mathrm{~kW}$ installed capacity are running in Pakistan. The solar energy share of the country is rising continuously. Yet, in order to decrease the power cut duration, incredible measures are still required. In northern areas, Pakistan can also use its geothermal resources, but unfortunately, no effort has been done to utilize them, due to a lack of investment and manpower [19].

Biomass can serve as another versatile renewable energy resource to bridge the energy supply and demand gap of the world in various energy applications such as electricity, transport, and buildings [20]. It has a $14 \%$ share in the total $18 \%$ of the world's renewable energy share. Raw material for biomass can be obtained from agricultural and forest leavings, industrial and municipal leftovers, and waste materials. Pakistan, as an agricultural country, holds a great capability to harvest energy from biomass comprising of waste that comes from crops such as wheat, rice, and sugarcane. Established poultry and livestock industries also leave behind excessive poultry and livestock ordure, which being organic in nature, can be processed to retrieve energy. A fresh study of the World Bank states a potential of 4000-6000 MW power generation using biomass. The Punjab government has projected a potential of 
$1500 \mathrm{MW}$ of power generation through biomass that is used as fuel and $1000 \mathrm{MW}$ of power through solid waste. It has been observed that the waste heat from the cement and chemical industries can be used to generate electricity that can be sold to the grid. Between 200-400 MW of electricity can be produced by waste heat recovery, according to recent estimates by the 2016 state of industry report [21].

The 2010-2035 global policies suggest an urgent imposition for bioenergy, excluding traditional biomass, with a required 3.3\% annual increase i.e., 526 MTOE (2010) to 1200 MTOE (2035). However, by 2035, bioenergy will hold a greater share in the power sector, as mentioned in Figure 4 [22]. Biomass is an exclusive form of source of green and clean energy; it is also abundantly instituted in nature and can be produced easily both in urban and rural environs [23,24]. Biomass resources are segmented in three classes, as shown in Table $2[25,26]$.

\section{0/1227 MTOE}

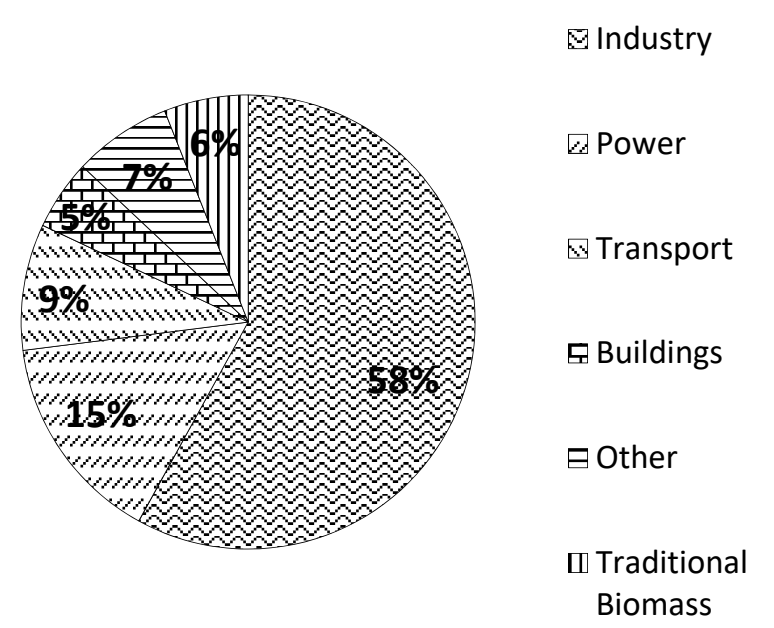

\section{5/1881 MTOE}

Figure 4. World bioenergy use by sector and use of traditional biomass in the new policy scenario (2010-2035).

Table 2. Biomass sources.

\begin{tabular}{cc}
\hline Biomass Source & Types \\
\hline Wastes & $\begin{array}{r}\text { Agricultural production wastes, crop residues, agricultural } \\
\text { processing wastes, urban organic wastes, urban wood wastes, } \\
\text { and mill wood wastes. }\end{array}$ \\
Forest products & $\begin{array}{r}\text { Wood, trees, shrubs and wood residues, logging residues, } \\
\text { sawdust and bark from forest clearing. }\end{array}$ \\
Energy crops & $\begin{array}{r}\text { Starch crops (corn, wheat, and barley), sugar crops (cane and } \\
\text { beet), oilseed crops (soybean, sunflower, and safflower), short } \\
\text { rotation woody crops, herbaceous woody crops and grasses. }\end{array}$ \\
\hline
\end{tabular}

The advantage of obtaining energy from biomass resources is that the output is closed to the installed capacity, unlike other renewable resources [27], which can be witnessed in Figure 5. Furthermore, the production of thermal energy using biomass has less effects on the environment. Thus, energy harnessed from biomass resources is popular development in Pakistan as compared to other systems of renewable energies [28]. In early days, different biomass such as leaves, wood, and excrement have been used as energy resource in daily life. Despite the overriding of biomass by fossil fuels in both urban and rural regions since the industrial revolution, biomass is slowly becoming reaccepted as an energy supply at the industrial scale [29]. 


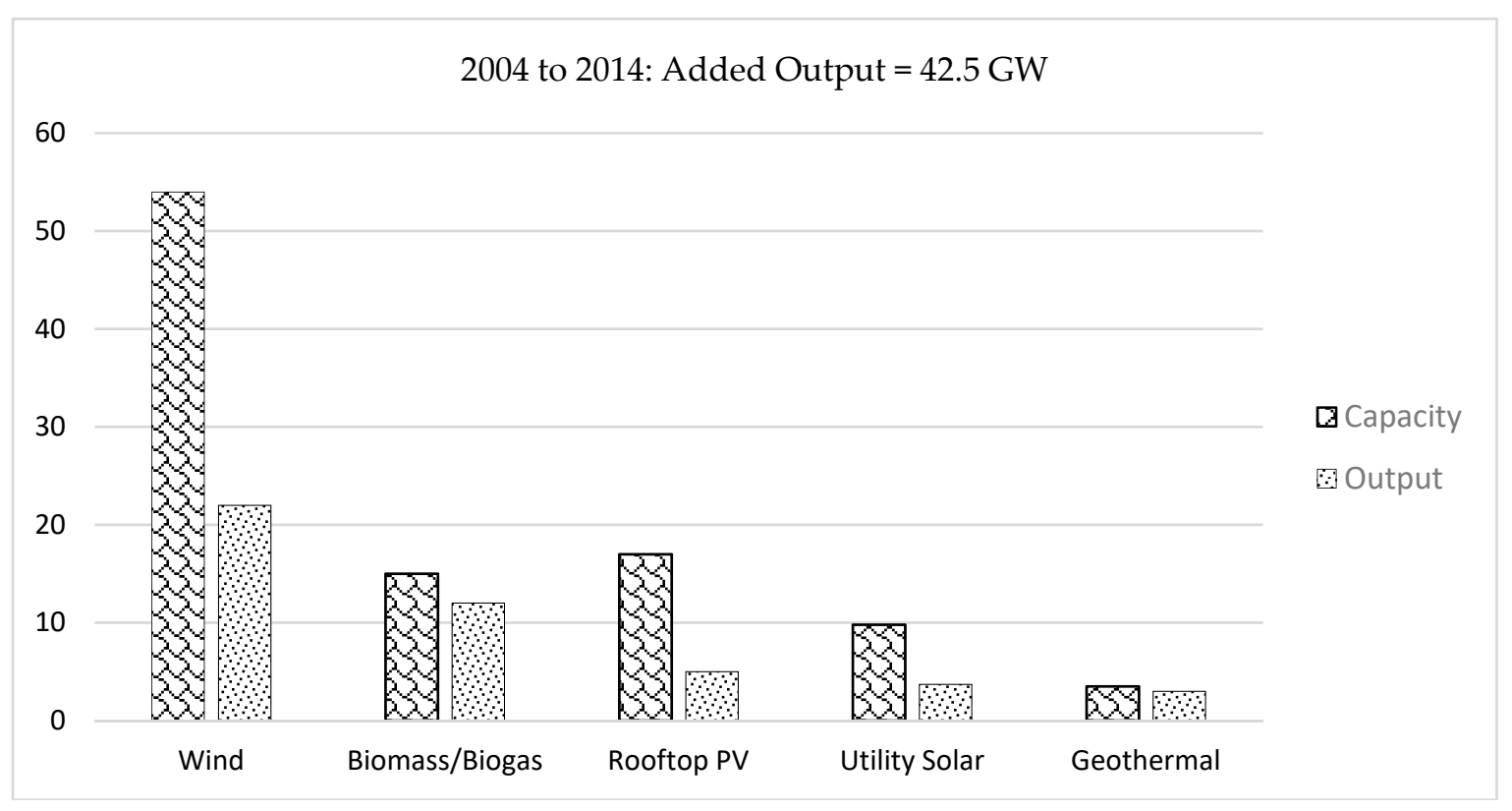

Figure 5. Output vs. installed capacity for various global renewable sources.

Research and development is being carried out for various technologies of producing biomass energy $[30,31]$. Electricity generation based on gasification technology has been practiced for more than a century. Anaerobic digestion and the combustion of biomass are developed and established technologies compared to gasification. In study [31], Bhattacharya demonstrate a biomass energy to co-firing with coal energy [32,33], and it is well developed in agro-industries. Additionally, biodiesel and bioethanol-based energy production are a few of the most striking biomass energy technologies in the current era [34].

This paper briefs the necessity of upgrading Pakistan's power sector by using the renewable resources. Some of the previous research studies in this domain only targeted one specific resource or two, while other research studies have targeted all of the resources. However, their analyses do not provide an insight as to which resource can quickly lessen the gap between energy demand and supply in the current situation in Pakistan. The first step toward the successful implementation of a renewable energy resource at a large scale is to study the various perspectives of all the available resources, and then opt for the most optimal and feasible one by properly analyzing all of the aspects of each resource. A comprehensive analysis has been done in this paper on the state, demand predictions, and existing sources of power generation in Pakistan using conventional, alternate, and renewable energy resources, along with global scenarios to comprehend where Pakistan stands in the world in terms of power and energy. This approach can help the government make decisions about the prioritization and utilization of resources, which will enable investors to wisely invest in high-priority resources based on facts and the potential advantages and disadvantages of individual resources. This study shows that the geolocation of Pakistan makes the place ideal for the implementation of any kind of alternate or renewable energy systems based on hydropower, thermal power, nuclear power, wind, solar, geothermal, and biomass power plants. It also discusses the biomass resources such as bagasse, municipal waste, and poultry waste to harvest biomass energy for power generation, transportation, and industrial fuel. Keeping in view the availability, sustainability, and lowest environmental impact of biomass energy, this paper concludes that the energy policies of Pakistan are in dire need of revision in order to bridge the demand and supply gap by bringing up projects based on renewable energies, especially biomass-based energy projects that hold enormous energy and fuel potential.

This paper has been structured in four main sections. Sections 2 and 3 critically review the existing demand and future sources of power generation predictions based on different power plants in Pakistan. The existing and future scenarios of biomass applications in electricity generation, 
transportation, and its use as an industrial fuel are the focus of Section 4. The discussion and recommendations have been presented in Section 5, in comparison to the existing energy situation of Pakistan. Finally, a conclusion is presented in Section 6. A graphical representation of the research methodology is also presented in Figure 6.

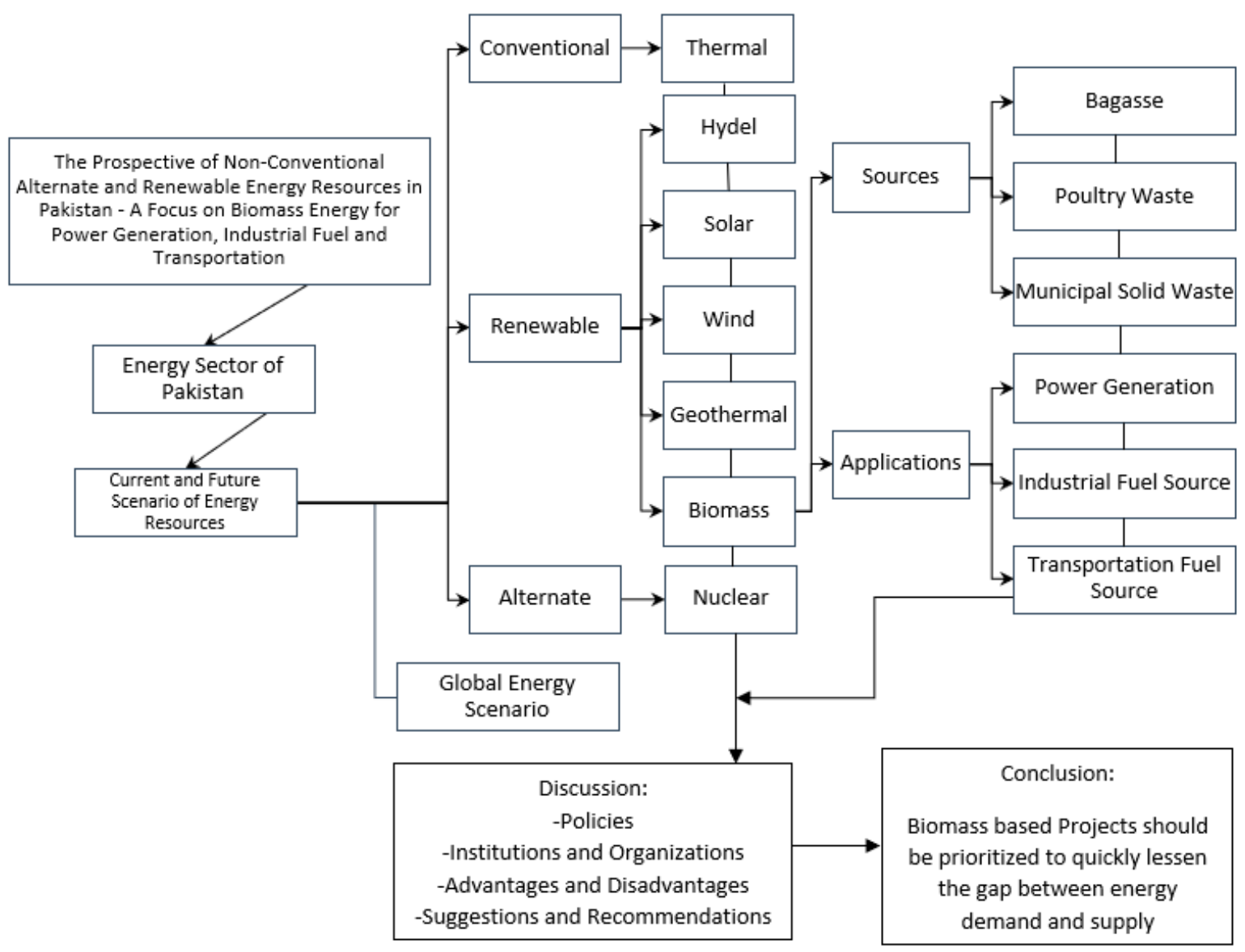

Figure 6. Graphical representation of the research methodology.

\section{Energy Sector of Pakistan}

A worldwide evaluation of energy policies has been carried out to meet the gap between supply and demand [35-38]. So, Pakistan's national power policy has the key objective of providing an efficient electricity supply system by transition of the country's electricity industry from the public sector toward potential efficiency improvements from private enterprise, because the public sector has been facing various constraints over the last two decades. Since 1994, the Government of Pakistan $(\mathrm{GoP})$ has been following a policy of commissioning new generation capacity in the private sector via independent power producers (IPPs) [39,40]. Public and private sector (IPPs) contribute 53.64\% and $46.36 \%$, respectively, to the installed capacity of Pakistan. There has been an elevation in the overall installed capacity for power generation of Pakistan i.e., 24,961 MW in 2015 to 24,961 in 2016, representing an increase of $1.65 \%$. The National Transmission and Dispatch Company (NTDC) and K-Electric's (K-EL) power plants generated 112,033 GWh as of 2016, relative to 108,916 GWh as of 2015 [21]. An overview of the power sector and discussion about its current generation capacity is given in the following sections.

\subsection{Hydropower}

Hydel power is a clean, cost-effective, and renewable energy source. Also, it shows a quick response with a fast varying load [41,42]. Keeping in view its advantages, more than 150 nations 
have established hydel power generation plants, which constitute about $16 \%$ of the world's power generation $[43,44]$. Results deduced by a comparison of electricity generation from hydropower and other renewable sources between 2010-2016, as shown in Figure 7, illustrate that hydropower electricity generation has three times greater efficiency than other sources [45]. The total renewable capacities of the top six countries are presented in Figure 8. As seen, China has the largest hydropower resource potential, with a capacity of $542 \mathrm{GW}$ and $2470 \mathrm{TWh}$ annual generation as of $2016[45,46]$.

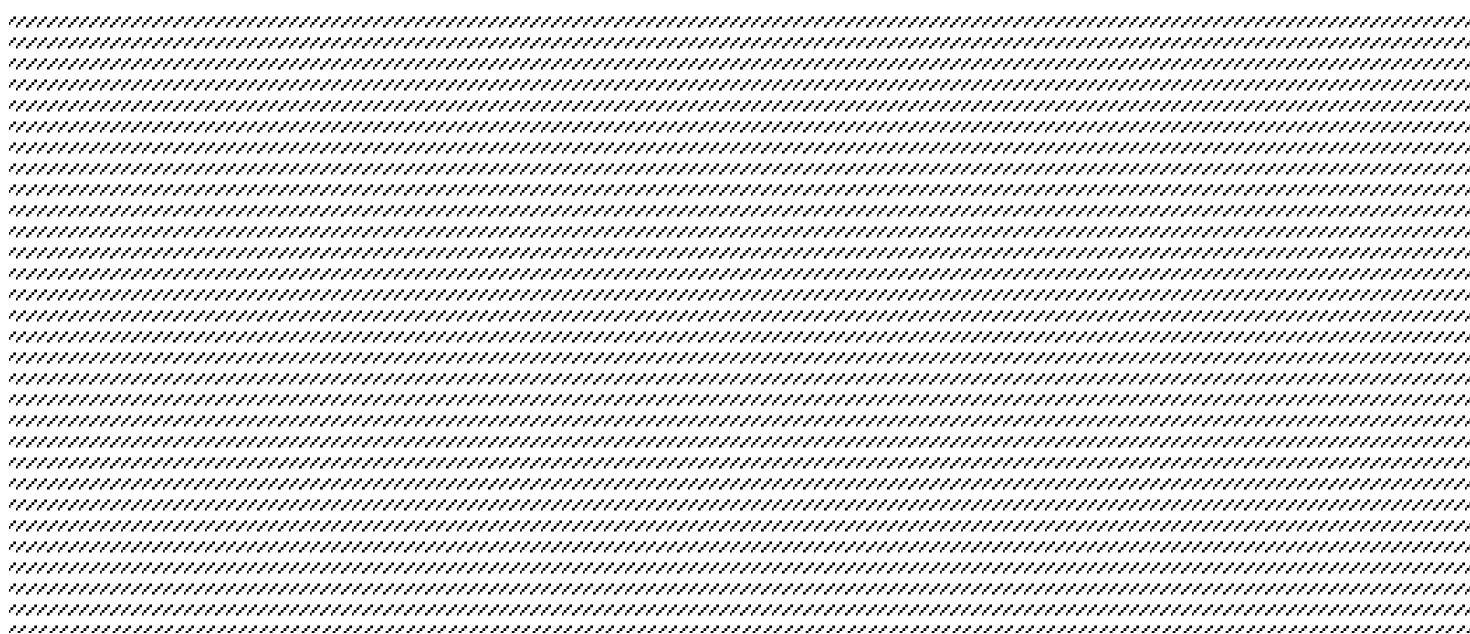

Figure 7. Worldwide electricity production for the period 2010-2016.

Hydro has remained a chief pillar of economical energy production in Pakistan. During 1960, this method generated $70 \%$ of the total electricity of the country, whereas by 2014 , it had declined to only $30 \%$ (7000 MW). This constitutes $9 \%$ of the overall power produced from primary sources [47].

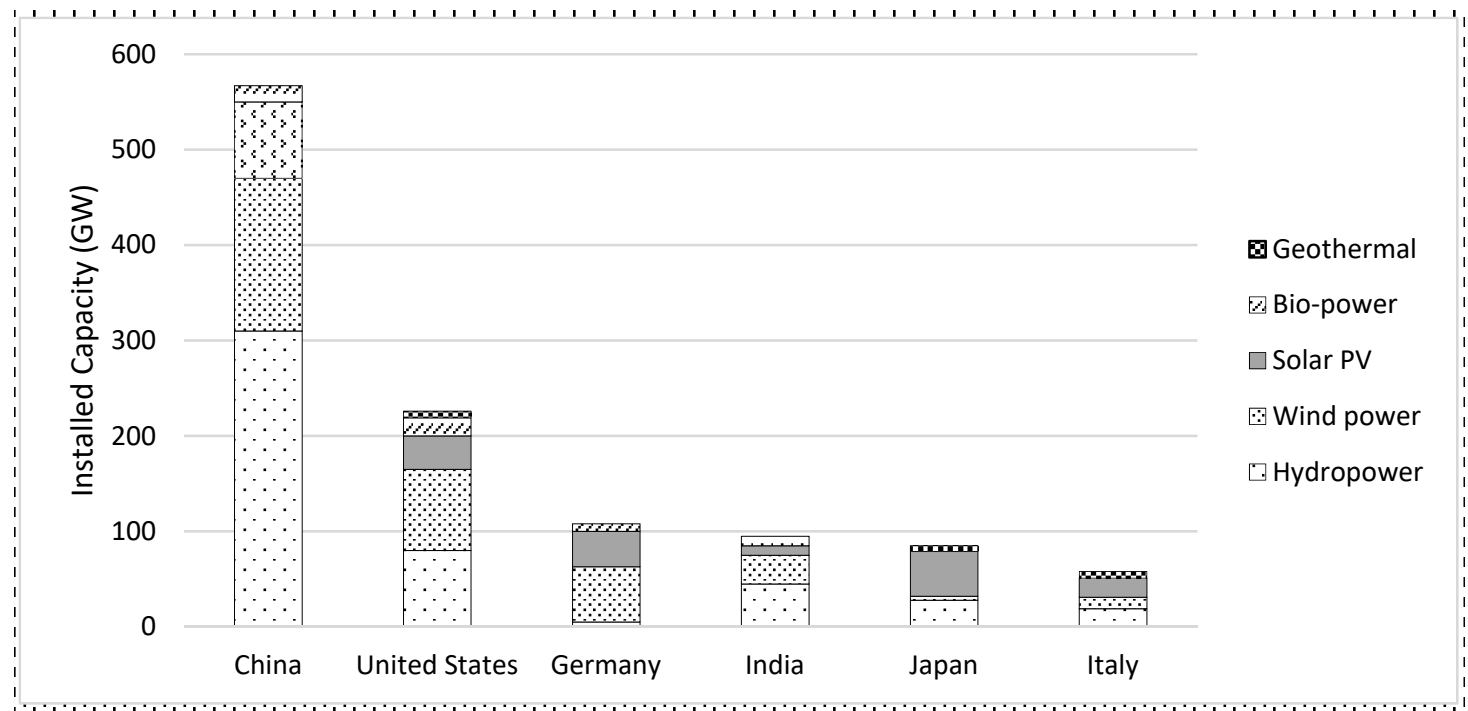

Figure 8. China has the world's largest total hydropower capacity.

Pakistan can tap its lakes, rivers, and waterfalls to generate hydro energy, which accounts for enormous potential of energy generation. For hydel-based electricity generation installations, several new locations have been chosen [48]. Pakistan's inability to sustain a hydropower share in the total electricity produced is one of the leading reasons for its energy crisis. In 2015, the overall share increased by an insignificant amount of $1 \%$, making its share $31 \%$. The loss of its share is due to the GoP's inability to establish new power production plants and trail the power requirement, as shown in Figure 9. Whereas, during this period, electricity production using thermal sources rose to $65 \%$ from 
$42 \%$ [49]. Owing to a decrease in the generation capacity, hydel power generation is prone to encounter limitations based on a deficit of water, mostly in winters. Limited reservoirs and dams further add to this problem [50].

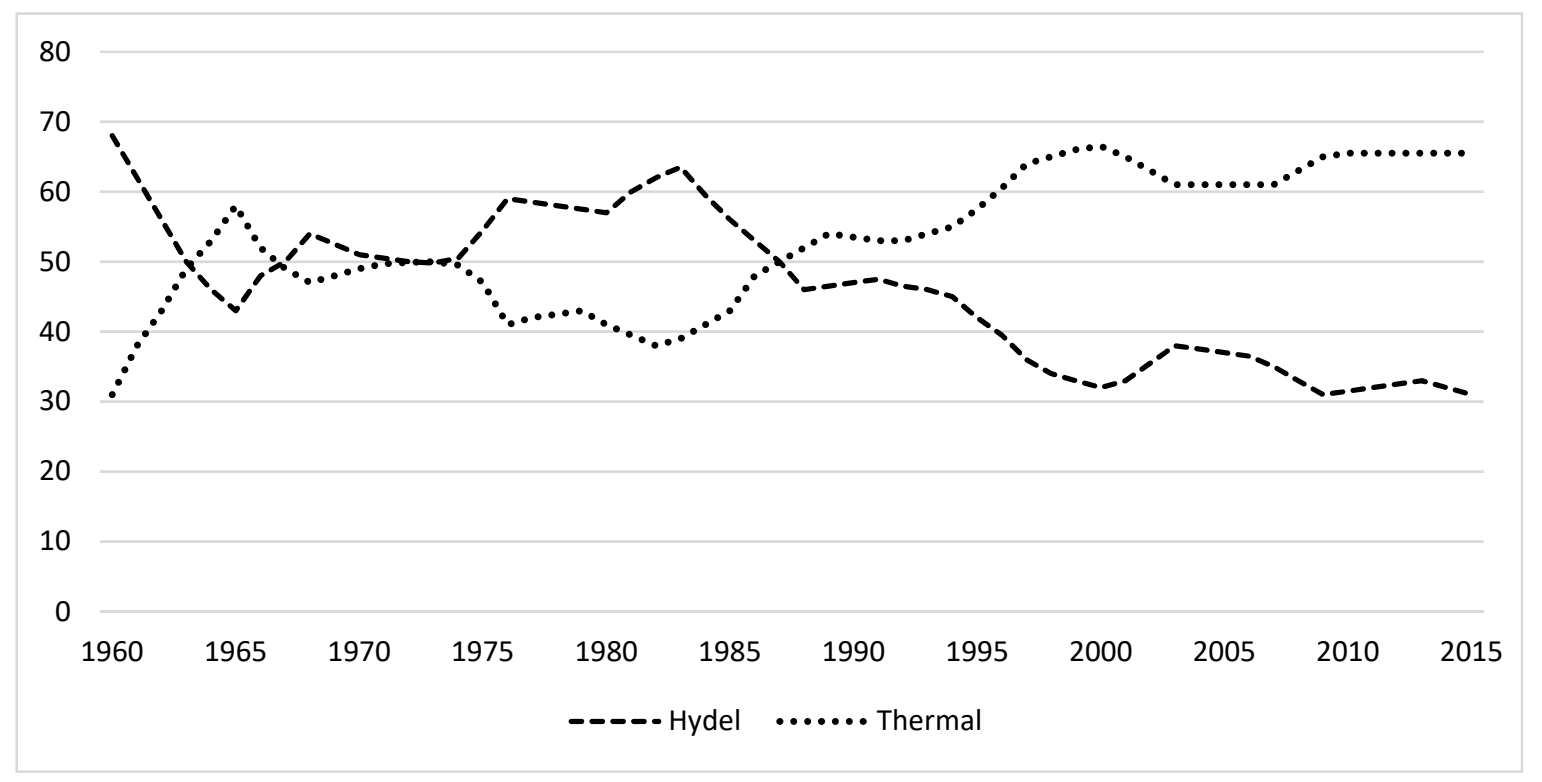

Figure 9. Decreased share of hydel in electricity generation from 1960-2015 in percentage.

For Pakistan, as a developing country, the ultimate preference could be hydropower, since it is inexpensive, plentiful, and a native source for renewable energy production. The expense for hydro energy production is approximately PKR 2-3/kWh, while using natural gas costs PKR 4-6/kWh. Likewise, the utilization of high-speed diesel (HSD) and residual furnace oil (RFO) for electricity production is five times more expensive than hydel i.e., PKR 15-18/kWh [43,51].

In the late 1970s, even with the worthwhile advantages offered by hydel, no remarkable accommodations were made after the establishment of the Tarbela and Mangla dams. Ghazi Brotha was the last significant venture; it was made in 2002, bringing $1450 \mathrm{MW}$ capacity to the grid. Since then, no noteworthy investment has been made. From 2004 to 2012, the demand has increased by 27.5\%, and overall capacity has increased by only $16 \%$. Talks about the Kalabagh Dam and Diamer Bhasa Dam with $3600 \mathrm{MW}$ and $4500 \mathrm{MW}$ capacity, respectively, have been ongoing, but due to a lack of finance [52] and political problems [53], they have not been realized [54].

Table 3 shows an empirical analysis of the hydel portfolio in Pakistan. It is observable that while the $0.15-50 \mathrm{MW}$ range covers the three classes, all of the projects having greater than $50 \mathrm{MW}$ are taken as large hydrosystems. It has been suggested that adding more categories to the $450 \mathrm{MW}$ section would render easier planning and estimation. The proposed categories are medium hydro, large hydro, and mega hydro, with capacities of 50-499 MW, 500-1000 MW, and 41,000 MW, respectively. Large and mega projects can expectedly have disparate scales of ecological and socioeconomic influence across notably different geographical locations and time scales [55].

Table 3. Pakistan's hydropower portfolio. MW: megawatt.

\begin{tabular}{|c|c|c|c|c|c|c|}
\hline \multirow[b]{2}{*}{ Category } & \multirow{2}{*}{$\begin{array}{c}\text { Cumulative } \\
\text { Capacity } \\
\text { (MW) }\end{array}$} & \multirow{2}{*}{$\begin{array}{c}\text { Total } \\
\text { Projects }\end{array}$} & \multicolumn{2}{|c|}{ Functional } & \multicolumn{2}{|c|}{ Under Development } \\
\hline & & & MW & $\begin{array}{c}\text { Number of } \\
\text { Projects }\end{array}$ & MW & $\begin{array}{c}\text { Number of } \\
\text { Projects }\end{array}$ \\
\hline Micro hydro: $<0.15 \mathrm{MW}$ & 6.62 & 79 & 1.93 & 20 & 0 & 0 \\
\hline Mini hydro: $0.15-5 \mathrm{MW}$ & 607.6 & 518 & 89.44 & 97 & 158.5 & 66 \\
\hline Small hydro: 5-50 MW & 2020 & 123 & 196 & 13 & 719 & 42 \\
\hline Large Hydro: >50 MW & 57,160 & 82 & 6433 & 6 & 29,162 & 43 \\
\hline
\end{tabular}


The thought of micro hydel is not new for Pakistan; the still functional power station established in 1925 at the Bambawali Ravi Bedian (BRB) Canal in Renala generates 1.1 MW of power. The cumulative micro hydel potential at a total of 815 natural waterfalls and run-of-river sites is $3100 \mathrm{MW}$ in the country. Major hydel projects under development under the Water and Power Development Authority (WAPDA) are shown in Table 4 [15].

Table 4. Hydropower projects under development in Pakistan. COD: commercial operation dates.

\begin{tabular}{cccc}
\hline Sr. No. & Dam & Capacity (MW) & Expected COD \\
\hline 1 & Neelum Jehlum & 969 & December 2017 \\
2 & Dasu & $2 \times 2160$ & 2025 \\
3 & Diamir Bhasha & 4500 & $2019-2020$ \\
4 & Keyal Khwar & 128 & January 2020 \\
\hline
\end{tabular}

There was an addition of 1908 GWh to the total hydropower energy generation in 2015-2016 as compared to 2014-2015, making up a total of 33,433 GWh energy production, while WAPDA's hydropower installed capacity persisted on 6902 MW from 2014-2016. Likewise, in 2015-2016, the hydel-based IPPs made a contribution of $52 \mathrm{GWh}$, and the installed capacity remained the same as that of 2014-2015. Throughout the year, the electricity production trend from hydropower has been consistent with the historical trends. For 2015-2016, operation and readiness was observed to be acceptable [21]. To inspire the installment of hydel-based projects, the GoP has permitted a 17\% internal rate of return for such projects [54].

\subsection{Thermal Power Source}

The use of thermal energy has been greatly expanded in every sector of life, such as the residential industrial and commercial sectors e.g., for cooling and heating purposes. The IEA predicted that the need for thermal energy will persist in the near future. For thermal energy generation, primary sources are fossil fuels such as coal, oil, and natural gas. Nuclear reactors are also used in this regard [56].

Pakistan has a mixture of thermal, hydro, nuclear, and renewable energy power plants for electricity generation. In 1985 , the ratio of installed capacity of hydel to thermal was $67 \%$ to $33 \%$, but later, more power started to be generated thermally, lessening the electricity generation from hydel. As of 2016, the hydel-to-thermal ratio became 30:65, thus indicating a dilemma that Pakistan's power sector mainly relies upon thermal power plants that feed on oil and gas [57-59].

As of 30 June 2016, Pakistan had a total of 25,374 MW power generation capacity, out of which 16,619 MW i.e., $65.5 \%$ was harnessed from thermal power plants. Table 5 shows the various fuels utilized and percentage share of overall fuel consumed for electricity generation using thermal resources from 2010 to 2015 [21]. Pakistan is working on the three Regasified Liquefied Natural Gas (RLNG)-based power plants, which are expected to be functional as per the dates mentioned in Table 6. It has been observed that the public thermal power plants of Pakistan have been lacking in all of the key performance indicators (KPIs) for many years, and are functioning at below the rated capacities and efficiencies, contributing toward an overall higher cost of generation, since demand is increasing and the production has been lowered [60]. 
Table 5. Fuel consumption for thermal power production in tons of oil equivalent (TOE).

\begin{tabular}{|c|c|c|c|c|c|c|c|}
\hline Fiscal Year & Unit & Gas & Furnace Oil & Diesel Oil & Coal & Total & $\begin{array}{c}\text { Annual Growth } \\
\text { Rate (\%) }\end{array}$ \\
\hline \multirow{2}{*}{ 2010-2011 } & TOE & $6,493,766$ & $7,827,500$ & 105,160 & 43,169 & $14,469,595$ & \multirow{2}{*}{-8.22} \\
\hline & $\%$ share & 44.88 & 54.10 & 0.73 & 0.3 & 100 & \\
\hline \multirow{2}{*}{ 2011-2012 } & TOE & $6,732,876$ & $7,206,839$ & 203,072 & 46,800 & $14,189,587$ & \multirow{2}{*}{-1.94} \\
\hline & $\%$ share & 47.45 & 50.79 & 1.43 & 0.33 & 100 & \\
\hline \multirow{2}{*}{ 2012-2013 } & TOE & $7,084,177$ & $7,342,755$ & 218,584 & 28.204 & $14,673,720$ & \multirow{2}{*}{3.41} \\
\hline & $\%$ share & 48.28 & 50.04 & 1.49 & 0.19 & 100 & \\
\hline \multirow{2}{*}{ 2013-2014 } & TOE & $6,602,422$ & $8,486,744$ & 304,994 & 71,902 & $15,466,062$ & \multirow{2}{*}{5.40} \\
\hline & $\%$ share & 42.69 & 54.87 & 1.97 & 0.46 & 100 & \\
\hline \multirow{2}{*}{ 2014-2015 } & TOE & $6,847,894$ & $8,234,479$ & 565,953 & 67.638 & $15,715,964$ & \multirow[b]{2}{*}{1.62} \\
\hline & $\%$ share & 43.57 & 52.40 & 3.6 & 0.43 & 100 & \\
\hline
\end{tabular}

Table 6. New Regasified Liquefied Natural Gas (RLNG)-based projects under development in Pakistan.

\begin{tabular}{cccc}
\hline Name of Project & Capacity (Gross) & Progress & Expected COD \\
\hline Quaid-e-Azam Thermal Power Project, Bhikki & 1180 & 52.30 & 20 December 2017 \\
Haveli Bahadur Shah Power Project & 1230.5 & 35.78 & 9 January 2018 \\
Balloki Power Project & 1223 & 38.1 & 30 January 2018 \\
\hline
\end{tabular}

The projects under the supervision of the public sector mostly face delays of various natures, extending from the need for enormous funds to ecological problems as well as technical limitations such as geological reservations [48]. Such delays are not tolerable for thermal projects, but still due to procedural formalities, projects such as 747 MW gas-based Guddu Power Plant, Nandipur Power Plant, and coal-based Jamshoro units 5 and 6 have been delayed [58,61]. Table 7 provides additional details, for the years 2015 and 2016, of power plants integrated with NTDCs and K-EL systems along with their installed capacity and electricity generation. Table 8 shows a list of thermal power plants along with their capacities [21].

Table 7. Thermal installed capacity and electricity generation for 2015 and 2016. CPP: captive power producers, IPP: independent power producers, GWh: gigawatt hours, K-EL: K-Electric.

\begin{tabular}{|c|c|c|c|c|c|c|c|}
\hline \multirow{2}{*}{\multicolumn{2}{|c|}{ As of 30 June 2016}} & \multicolumn{2}{|c|}{ Installed Capacity (MW) } & \multicolumn{4}{|c|}{ Electricity Generation (GWh) } \\
\hline & & 2015 & 2016 & 2014-2015 & 2015-2016 & Variation & $\%$ \\
\hline \multicolumn{2}{|c|}{ GENCOs with PEPCO } & 5762 & 5762 & 13,300 & 14,490 & 1190 & 8.95 \\
\hline \multicolumn{2}{|r|}{ K-EL Own } & 1874 & 1874 & 9319 & 10,323 & 1004 & 10.77 \\
\hline \multirow{2}{*}{ IPPs } & Connected with PEPCO & 8696 & 8696 & 44,369 & 44,591 & 222 & 0.5 \\
\hline & Connected with K-EL & 252 & 252 & 1525 & 1421 & 104 & 6.82 \\
\hline \multicolumn{2}{|c|}{ CPPs/SPPs connected with K-EL } & 35 & 35 & 191 & 139 & 52 & 27.23 \\
\hline
\end{tabular}

GENCO stands for power generation company, PEPCO stands for Pakistan Electric Power Company, CPP stands for captive power producers, SPP stands for small power producers, and K-E stands for K Electric.

Table 8. List of thermal power plants along with their capacities.

\begin{tabular}{cccc}
\hline Sr. No. & Plant & Capacity (MW) & Net Capacity (MW) \\
\hline 1 & Jamshoro Power Company Limited (GENCO-I): & 2344 & 1974.56 \\
2 & Central Power Generation Company Limited (GENCO-II) & 2431.7 & 2140.61 \\
3 & Northern Power Generation Company Limited (GENCO-III) & 2291.65 & 2001.19 \\
4 & Lakhra Power Generation Company Limited (GENCO-IV) & 150 & 93 \\
\hline
\end{tabular}

\subsection{Nuclear Power Source}

Energy sustainability and environmental challenges have gained global attention in the transition to alternate energy sources from fossil fuel utilization. Nuclear energy, as part of the alternate resources for energy production, is deemed capable for the prevention of ecological deterioration and 
maintenance of energy security, so there have been worldwide investments in many nations in this domain. A total of 447 nuclear power plants are operational around the globe, while another 287 are going to be functional by 2035. Figure 10 shows the global expansion of the usage of nuclear energy continuously [62]. Nuclear power plants do not emit greenhouse gases, ensuring a carbon-free base load electrical energy. Also, they require a relatively smaller footprint on land, which can be observed from Table 9 [63].

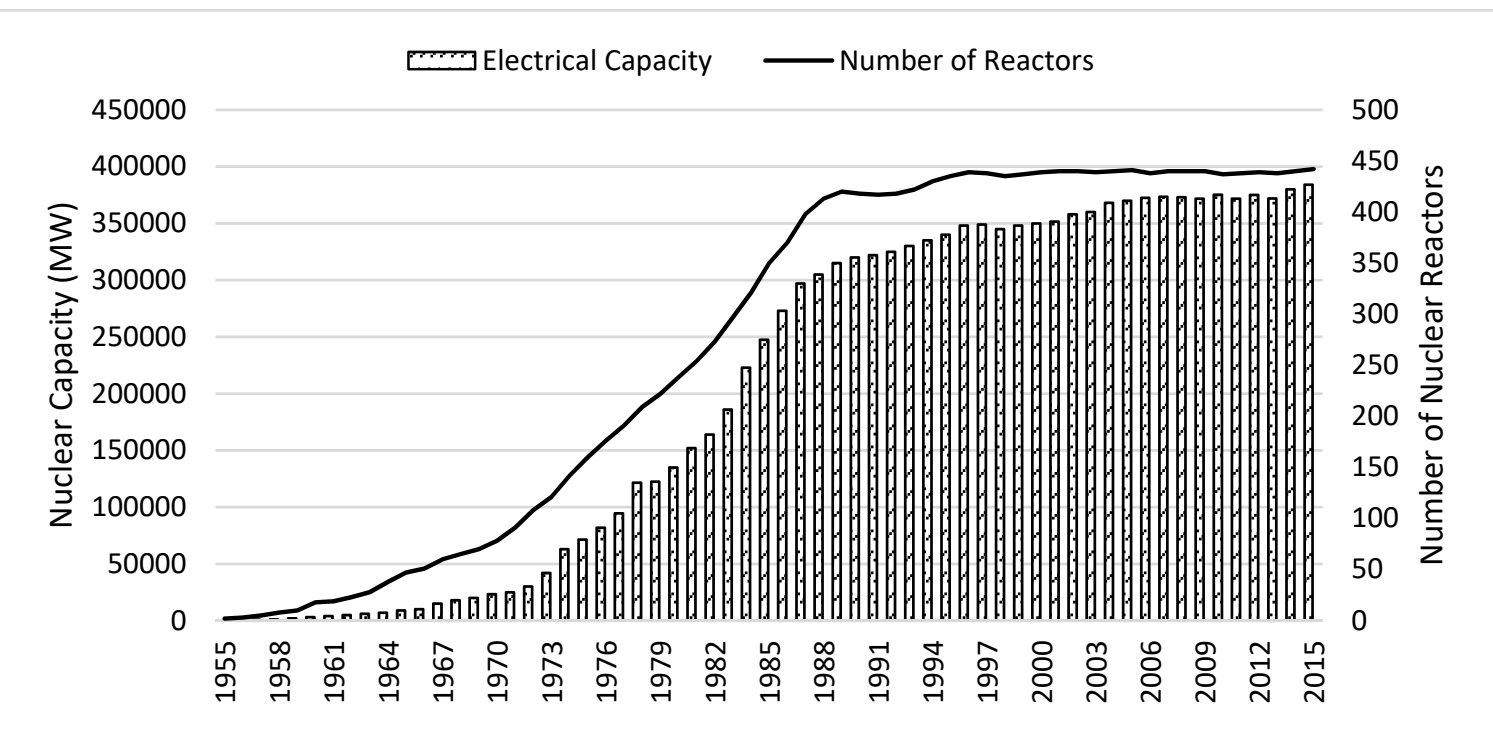

Figure 10. Global variation of functional nuclear plants with their total capacity (MW) between 1955-2015. 
Table 9. Data and ranks of power generation sources based on sustenance, economy, and environmental effects. GHG: greenhouse gas, PV: photovoltaic.

\begin{tabular}{|c|c|c|c|c|c|c|c|c|c|c|c|c|c|c|}
\hline \multirow{2}{*}{ Indicator (per TWh) } & \multicolumn{2}{|c|}{ Coal } & \multicolumn{2}{|c|}{ Natural Gas } & \multicolumn{2}{|c|}{ Nuclear } & \multicolumn{2}{|c|}{ Biomass } & \multicolumn{2}{|c|}{ Hydro } & \multicolumn{2}{|c|}{ Wind (Onshore) } & \multicolumn{2}{|c|}{ Solar PV } \\
\hline & Value & Rank & Value & Rank & Value & Rank & Value & Rank & Value & Rank & value & Rank & Value & Rank \\
\hline GHG emissions $\left(\mathrm{t} \mathrm{CO}_{2}\right)$ & $1,001,000$ & 7 & 469,000 & 6 & 16,000 & 3 & 18,000 & 4 & 4000 & 1 & 12,000 & 2 & 46,000 & 5 \\
\hline Electricity cost (\$ US) & 100.1 & 4 & 65.6 & 1 & 108.4 & 5 & 111 & 6 & 90.3 & 3 & 86.6 & 2 & 144.3 & 7 \\
\hline Dispatchability & A & 1 & A & 1 & A & 1 & B & 4 & B & 4 & $\mathrm{C}$ & 6 & C & 6 \\
\hline Land use $\left(\mathrm{km}^{2}\right)$ & 2.1 & 3 & 1.1 & 2 & 0.1 & 1 & 95 & 7 & 50 & 6 & 46 & 5 & 5.7 & 4 \\
\hline Safety (fatalities) & 161 & 7 & 4 & 5 & 0.04 & 1 & 12 & 6 & 1.4 & 4 & 0.15 & 2 & 0.44 & 3 \\
\hline Solid waste $(\mathrm{t})$ & 58,600 & 7 & NA & 1 & NA & 1 & 9170 & 6 & NA & 1 & NA & 1 & NA & 1 \\
\hline Radiotoxic waste & Mid & 6 & Low & 3 & High & 7 & Low & 3 & Trace & 1 & Trace & 1 & Trace & 1 \\
\hline Weighted rank & - & 6.0 & - & 2.0 & - & 1.3 & - & 6.7 & - & 3.3 & - & 2.3 & - & 5.3 \\
\hline
\end{tabular}


The capacity of nuclear power of the world is expected to rise to $416 \mathrm{GW}$ (2030) from $368 \mathrm{GW}$ (2005) [64]. Globally, 6\% of energy and 16\% of electricity is harnessed from nuclear energy. The Organization for Economic Co-operation and Development OECD nations account for 55\% of global uranium production. There was a rapid increase in global nuclear power consumption from $0.1 \%$ in 1970 to $7.4 \%$ in 1998, of which the major increase was observed in the 1980s [65].

Pakistan's electricity supply from nuclear resource is only $4.94 \%$ of the total supply; its provision takes place from Chashma Nuclear Power Plants I and II (CHASHNUPP I and II) and the Karachi Nuclear Power Plant (KANUPP) [66]. Two new units named Chashma-III and Chashma-IV have recently been constructed at the Chashma power plant site, each having a capacity of $350 \mathrm{MW}$. Two more units are also being constructed at the KANUPP site, which are expected to add $1100 \mathrm{MW}$ to the national grid by 2020. The Pakistan Atomic Energy Commission (PAEC), in collaboration with the GoP, intends the establishment of power plants based on nuclear reactors by 2030, with a capacity of 8800 MW. Figure 11 shows the nuclear scenario of installed capacities by PAEC from 2012 to $2030[66,67]$.

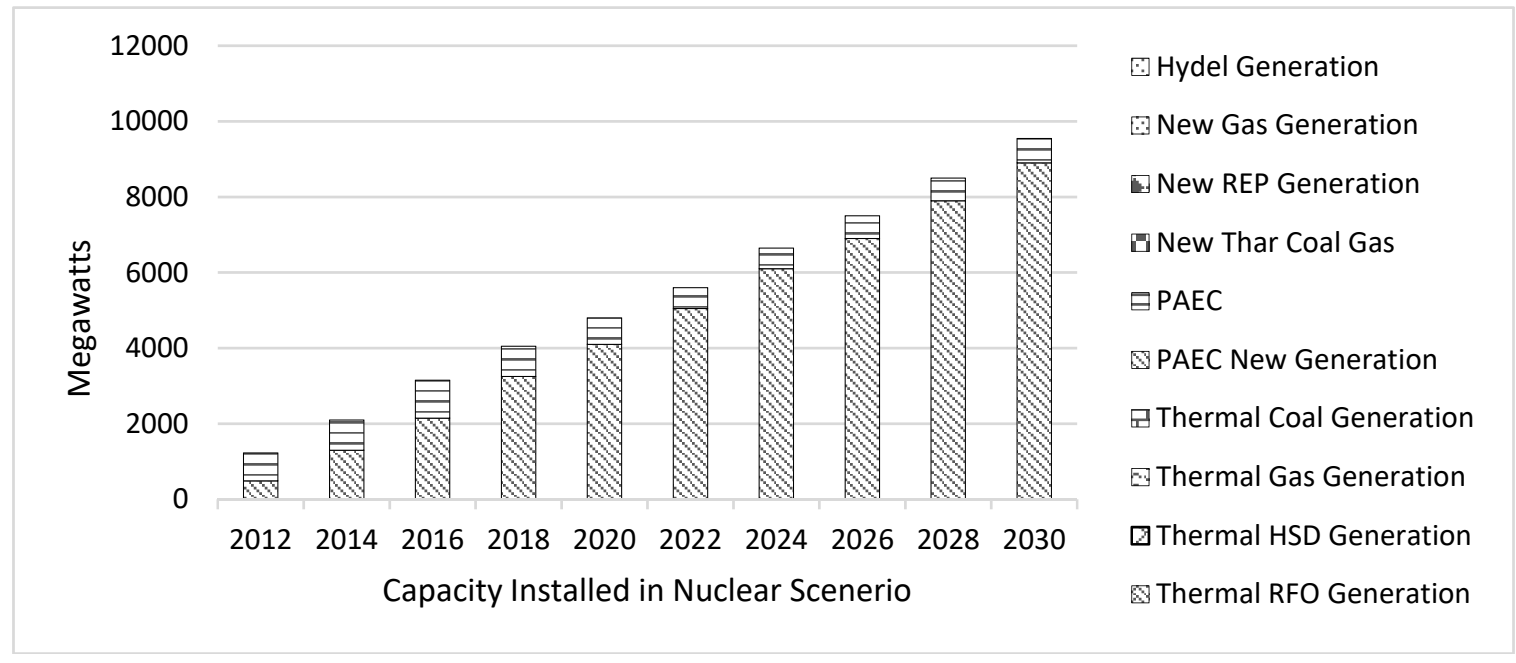

Figure 11. Nuclear scenario of installed capacities.

For 2015-2016, the NTDC-based nuclear plants had a steady installed capacity of $650 \mathrm{MW}$, which was the same as for the years 2014-2015, but the energy generation declined by 1142 GWh relative to 2014-2015 and stood at 3854 GWh for 2015-2016. No major power outage in the NTDC-based nuclear plants occurred, so they showed satisfactory performance during 2015-2016, except for one major issue i.e., the instability of the national electricity grid [21]. KANUPP has repeatedly faced shutdowns caused by fluctuations in the grid. Considering this menace, PAEC has worked on technical infrastructure improvement to support current and future nuclear power plants. Additionally, the facilities of in-house instructional and training centers covering all of the aspects of nuclear science and technology have been provided [16].

The cost of electricity from nuclear resources is greater than other sources, since the reactor fuel is expensive, and most of it is imported. Figure 12 shows the comparison of electricity costs from various sources. Among alternate energy sources, nuclear is the costliest, with a price of PKR $4.58 / \mathrm{kWh}$ [68]. With the intent to raise the share of nuclear power to $8.8 \mathrm{GW}$ by 2030, Pakistan would require 1600 tons of uranium. For that, the exploration, mining, and reprocessing of uranium in the country has been promised by the concerned authorities [69]. Also, by taking care of safety and health-related dangers, the encouraging impacts on the environment and national economic sustainability will increase nuclear-based electricity production. 


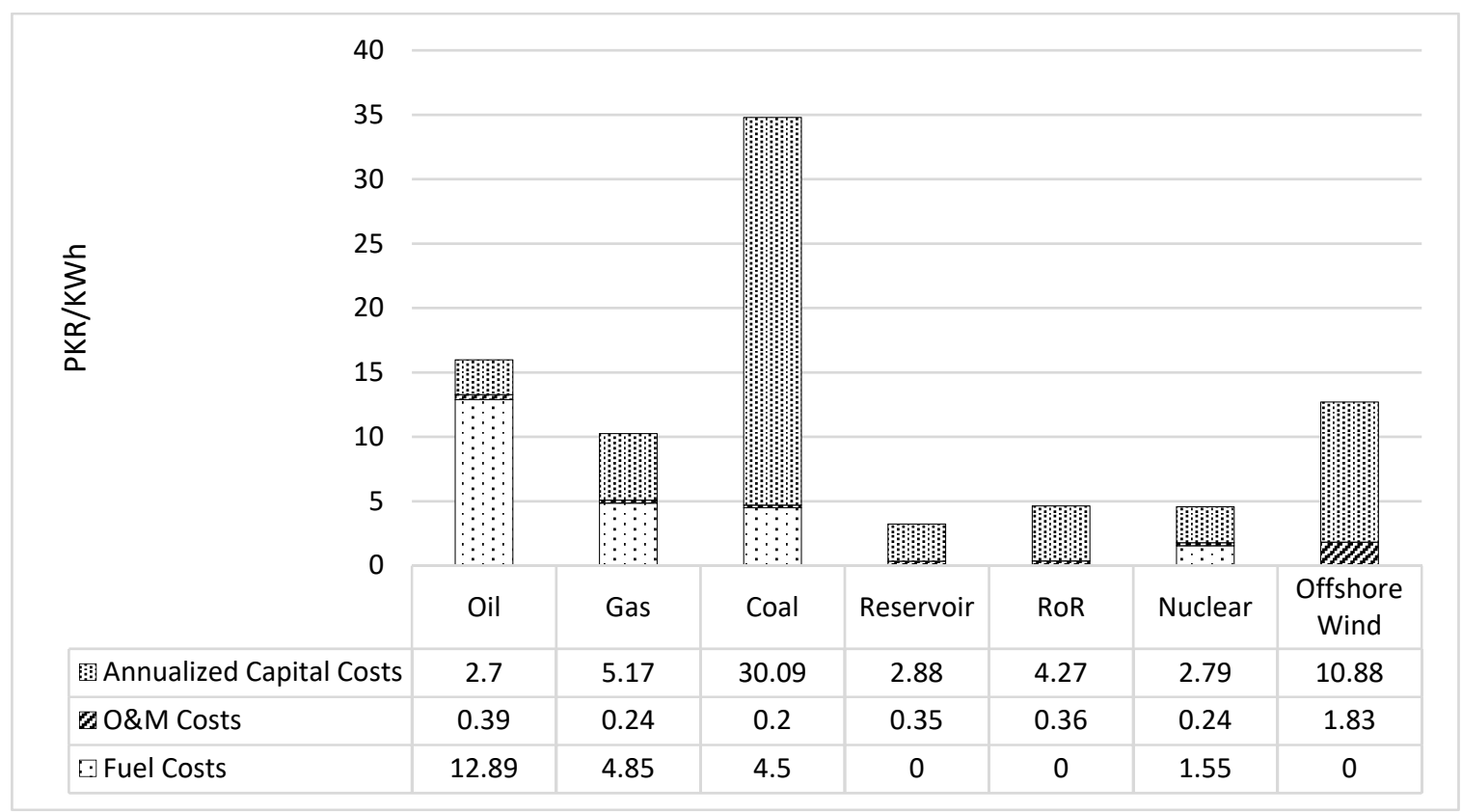

Figure 12. Comparison of electricity costs from different sources.

\subsection{Wind Power Source}

The GWEC (Global Wind Energy Council) reported that over 75 countries across the globe are generating electricity from wind energy, out of which 21 are producing more than $1000 \mathrm{MW}$. The total global installed capacity has increased to nearly $238 \mathrm{GW}$ due to an additional $40 \mathrm{GW}$ of capacity in 2011. Table 10 shows the top 10 countries that have the most capacities for wind power [70].

Table 10. Countries with top 10 wind power capacities.

\begin{tabular}{cc}
\hline Country & Installed Capacities \\
\hline China & $62,634 \mathrm{MW}$ \\
United States (USA) & $46,919 \mathrm{MW}$ \\
Germany & $29,060 \mathrm{MW}$ \\
Spain & $21,674 \mathrm{MW}$ \\
India & $16,084 \mathrm{MW}$ \\
France & $6800 \mathrm{MW}$ \\
Italy & $6737 \mathrm{MW}$ \\
United Kingdom (UK) & $6540 \mathrm{MW}$ \\
Canada & $5265 \mathrm{MW}$ \\
Portugal & $4083 \mathrm{MW}$ \\
World Total & $237.7 \mathrm{GW}$ \\
\hline
\end{tabular}

Harnessing energy from wind is one of the best choices amongst other sources of renewable energy due to its inexpensiveness, endlessness, and environmental friendliness [71]. Figure 13 shows the overall installed wind energy capacity from 1997 to 2014 [1]. The vision of 2030 is to increase the wind energy production up to 920 TWh with an increase rate of $3 \%$ [72], as compared to the $2.0 \%$ rate in 2007 [73]. The rate of increase was 20\% and 6\% in Germany and Denmark, respectively [74-76]. 


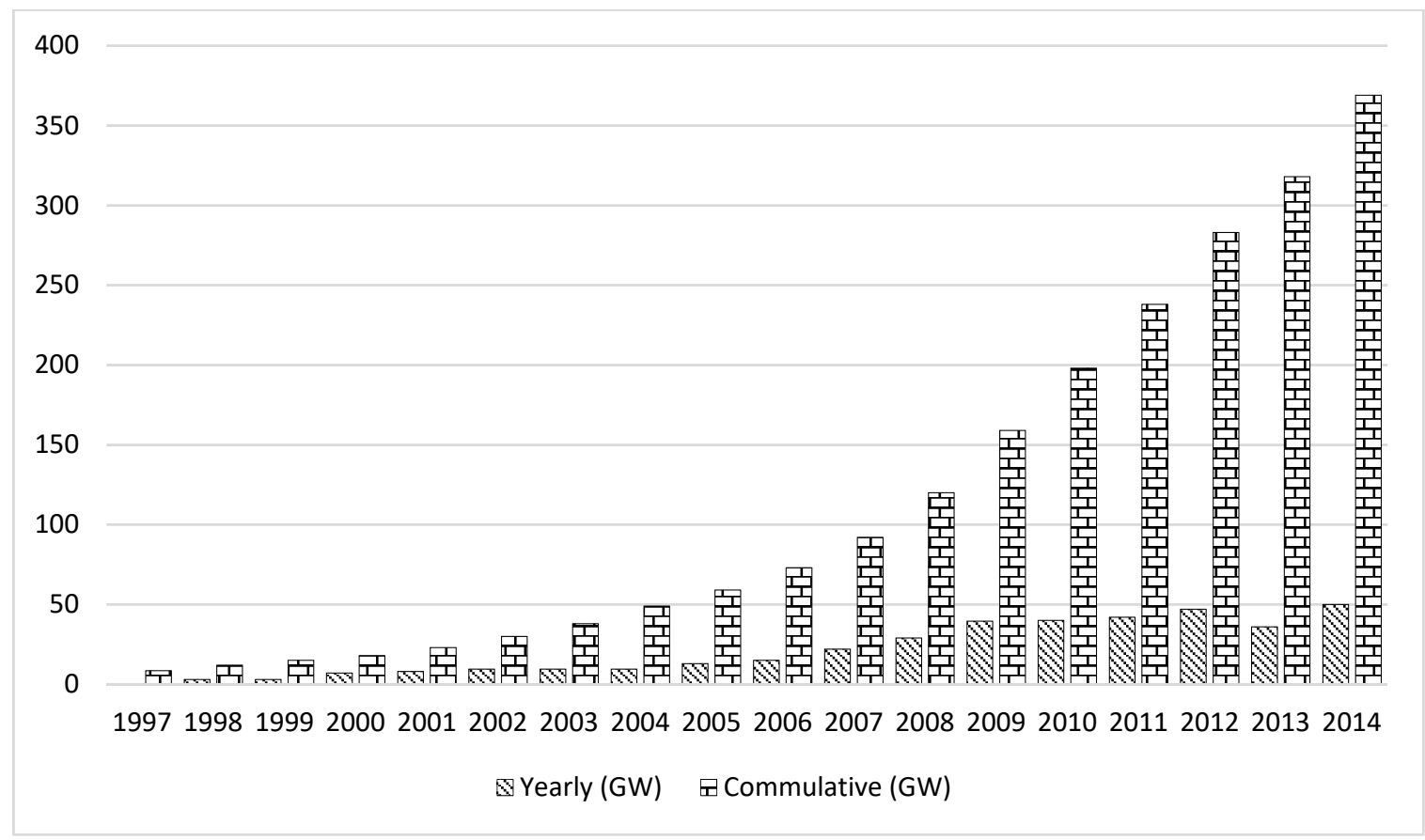

Figure 13. Overall installed wind energy capacity from 1997 to 2014.

Pakistan has enormous wind power resource potential. With the cooperation of the United States Agency for International Development (USAID), the Pakistan Meteorological Department, and the National Renewable Energy Laboratory (NREL); Pakistan's Alternative Energy Development Board (AEDB) established the very first wind map of the country, which provides a promising wind power potential of $346 \mathrm{GW}$ in different regions of Pakistan [59]. Figure 14 shows that according to the survey report of the NREL, Pakistan is capable of overall $346 \mathrm{GW}$ of power production from wind especially on the coastal areas of Sindh, where the velocity of wind is about $5-12 \mathrm{~m} / \mathrm{s}$, suggesting a potential of $20 \mathrm{GW}$ from such wind sites [77]. A study was carried out for the wind potential of Pakistan for non-offshore areas, considering the assumption that $5 \mathrm{MW} / \mathrm{km}^{2}$ is the installed capacity where the total land area of Pakistan is $877,525 \mathrm{~km}^{2}$, and it was found out to be 132,000 MW. It has been summarized in Table 11 [78].

A number of sites for the installation of wind energy production, with the aid of private sector producers, are under consideration by the AEDB. Ghoro-Keti Bandar has a $25 \%$ capacity factor, and a mean wind velocity of $7 \mathrm{~ms}^{-1}$ at a height of $50 \mathrm{~m}$; it is one of such sites with a power density of $400 \mathrm{~W} / \mathrm{m}^{2}$. Such sites can be utilized for commercially feasible wind farm projects. The evaluated capability for the power capacity of this site is more than 60 GW [79]. Nevertheless, the contribution of this site is insignificant, regardless of its considerable potential. From wind energy, the highest input of 106 MW was observed in 2014, producing only $0.2 \%$ of the total national electricity consumption [80]. Licenses have been granted to various companies by the AEDB. Several local and international companies have set up new projects. By 2030, the government is expecting a minimum of $30 \mathrm{GW}$ capacity from wind resources [81]. 


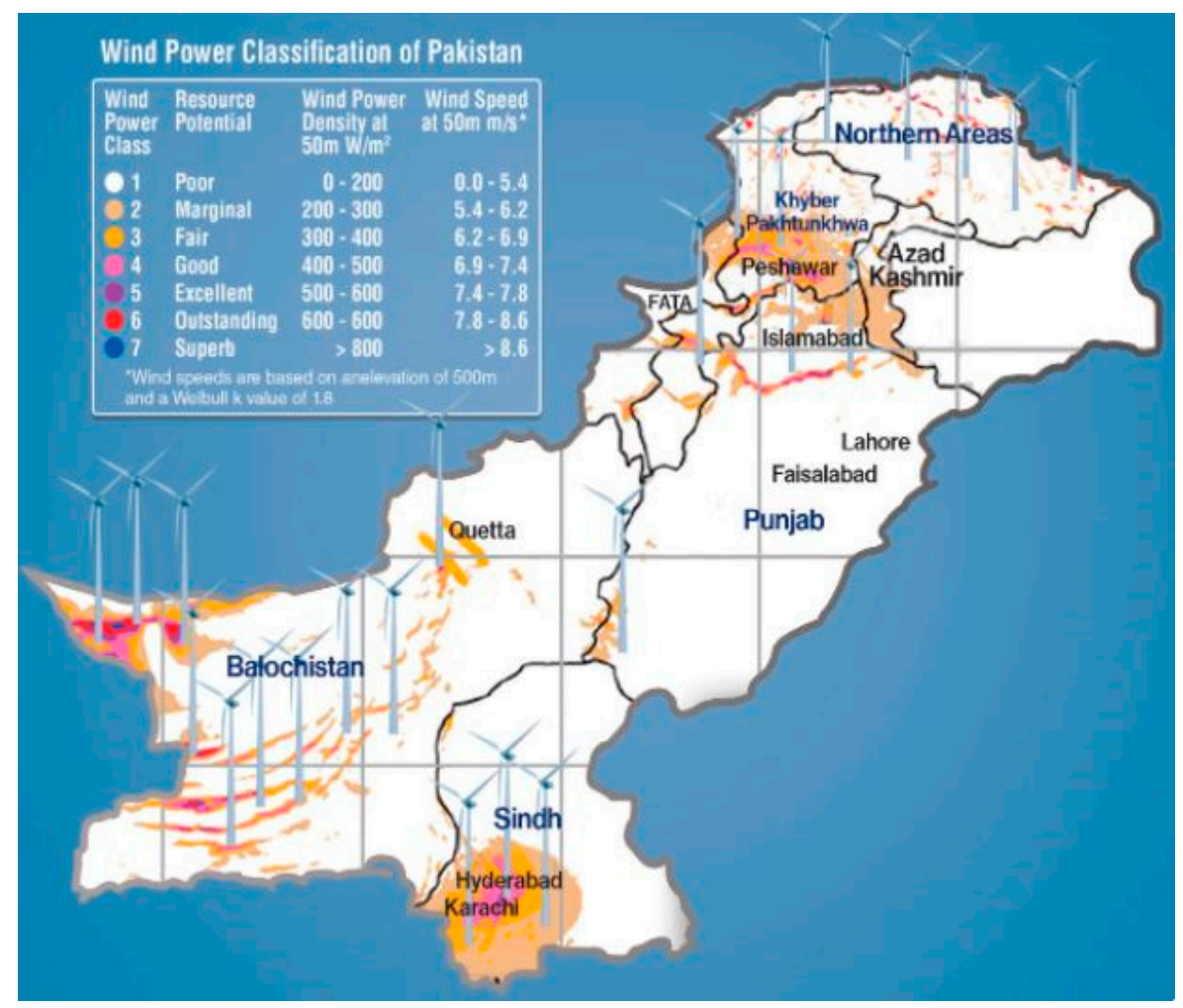

Figure 14. Wind power classification of Pakistan. $(1.96 ", 1.96)$.

During the financial year 2015-2016, an addition of 50 MW of wind power has been done in the system of the NTDC, for a total wind-based power of about $306 \mathrm{MW}$ in the system. The energy generated by wind-based power plants during the period 2015-2016 has been noted as $732 \mathrm{GWh}$ [21].

Table 11. Wind resource in Pakistan at $50 \mathrm{~m}$ from good to excellent.

\begin{tabular}{|c|c|c|c|c|c|}
\hline $\begin{array}{l}\text { Wind Resource } \\
\text { Quality Scale }\end{array}$ & Wind Class & $\begin{array}{c}\text { Power } \\
\left(\mathrm{kW} / \mathrm{m}^{2}\right)\end{array}$ & Speed $(\mathrm{m} / \mathrm{s})$ & Area $\left(\mathbf{k m}^{2}\right)$ & Capacity (GW) \\
\hline Good & 4 & $0.4-0.5$ & $6.9-7.4$ & 18,106 & 90.53 \\
\hline Very Good & 5 & $0.5-0.6$ & $7.4-7.8$ & 5218 & 26.09 \\
\hline Excellent & 6 & $0.6-0.8$ & $7.8-8.6$ & 2495 & 12.48 \\
\hline Excellent & 7 & $>0.8$ & $>8.6$ & 543 & 2.72 \\
\hline Total & & & & 26,362 & 131.8 \\
\hline
\end{tabular}

\subsection{Solar Power Source}

At the conclusion of 2015, the global installed capacity of solar-powered electricity approached $227 \mathrm{GW}$, producing 1\% of global electricity. The regions with relatively less solar resources i.e., Europe and China, have major solar installations, whereas those with more solar potential i.e., Middle East and Africa, are unexploited.

In the last 10 years, Germany has been leading solar photovoltaic (PV) installed capacity, and it is trailed by China, Italy, Japan, and the United States. Current electricity infrastructure can hinder the development of solar capacity, especially in novel solar markets. The renewable technologies of solar PV greatly depend on rare earth elements that may also have a supply interruption risk along with unsustainable mining procedures. Figure 15 shows the top solar PV capacity countries in 2014 and additions in 2015, where China has the highest capacity of 44 GW. After the addition of capacity in 2015, the total capacity became 59.2 GW [20]. 


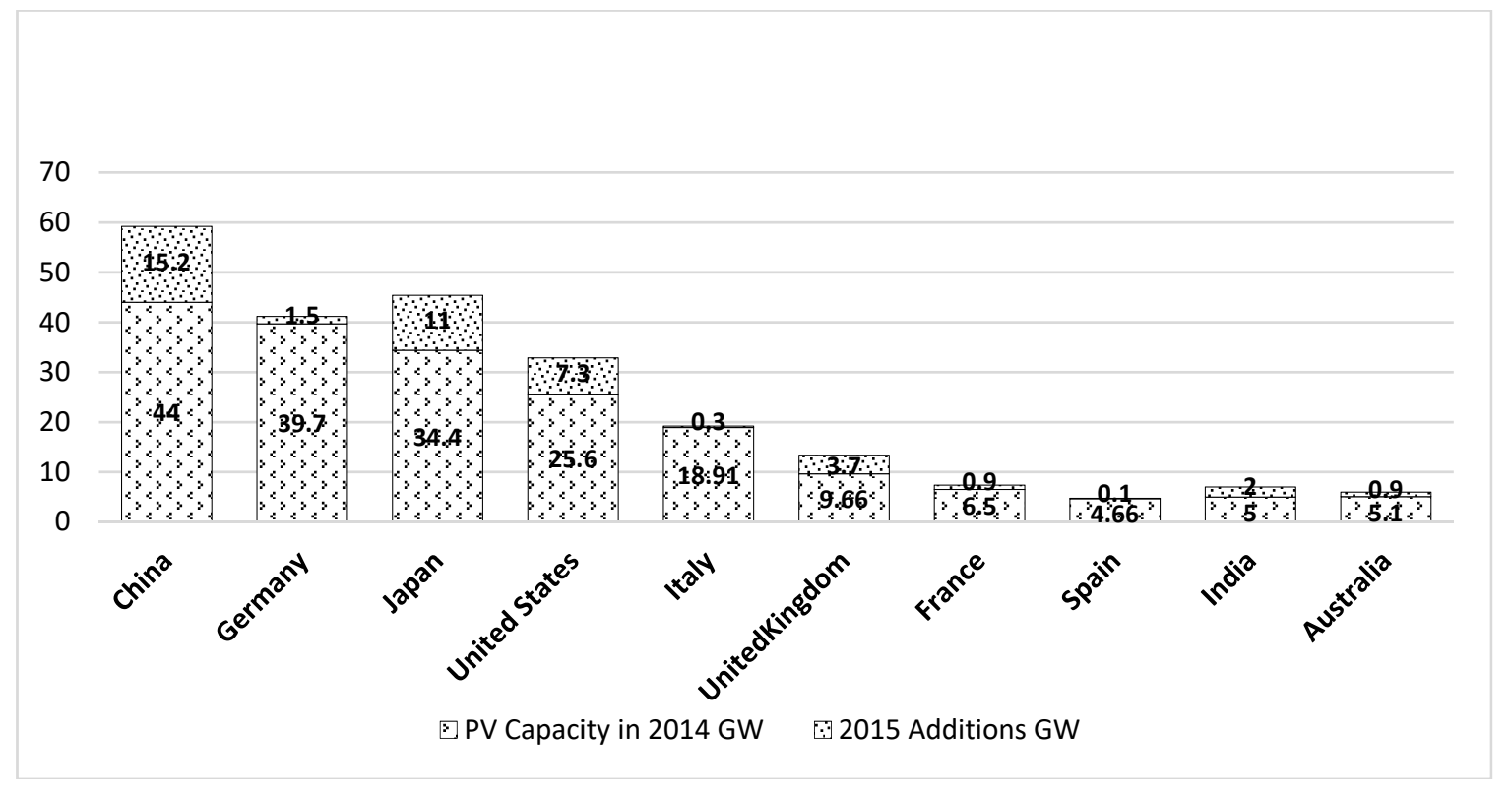

Figure 15. Top solar photovoltaic (PV) capacity in 2014 and additions in 2015.

On average, $5-7 \mathrm{kWh} / \mathrm{m}^{2}$ irradiance per day is received on $95 \%$ of the land of Pakistan. The expansive deserts in Sindh, Punjab, and Balochistan can provide sites for solar PV-based power plants installation where the sunlight strikes $2300-2700 \mathrm{~h}$ /year [14,48]. In a recent 2018 study regarding Pakistan's energy transition toward 100\% renewable energy by 2050, the domination of solar PV in the installed capacities of a completely renewable system by 2050 has been predicted, considering its lower costs and the tremendous state of solar resources. Figure 16 shows the collective installed capacity from all of the renewable resources by 2050, where the above-mentioned prediction can be observed [82]. The cost of off-grid solar PV has been calculated in a study for electrifying a household, which was calculated to be PKR 14.8/kWh less than the traditional supply [83].

In 2012, with funds from Japan under a project in Islamabad that aimed to introduce solar-based clean energy, the first solar-based electricity generation plant was established. Due to this project, two 178-kW capacity solar PV power plants were established in the vicinity of the Planning Commission of Pakistan and Pakistan Engineering Council. Pakistan's first solar park, which was called Quaid-e-Azam Solar park, has been constructed in Bahawalpur, which has a capacity of $1000 \mathrm{MW}$. Similarly, with the cooperation of private energy sector companies and China's aid, solar-based power generation plants are being installed in Kashmir, Punjab, Sindh, and Balochistan provinces [84]. Table 12 shows the solar PV projects that are under development along with their capacity and estimated Commercial Operation Dates (COD) [15].

Of the total primary energy supply, approximately $10 \%$ is utilized for water heating; thus, 100-500 W/ unit solar PV capacity systems have been planted [19]. Considering this, the number of imported solar water heaters rose to 16,715 from 260 between 2007-2013 phases. Renewable energy development organizations such as the AEDB, Pakistan Council Renewable Energy Technologies (PCRET), and private energy sectors have solar PV-based generation capacities of $200 \mathrm{~kW}, 80 \mathrm{~kW}$, and $500 \mathrm{~kW}$, respectively [85].

Solar PV systems are becoming more and more resourceful due to the research and development of PV technology, which is helping PV materials and PV inverters become exquisitely efficient, rendering the PV systems economical. However, time and huge investments are necessary for such commercial end products [86]. To make the public acquainted with solar technology, the provision of several energy-extraction technologies to 100 homes per province has been made for applications such as water portability, lighting, heating, and cooking. Keeping these advancements in view, the yearly 
power generation using solar technology is expected to be $1600 \mathrm{GW}$, and it has an ability to be a main power generation source in the impending future $[87,88]$.

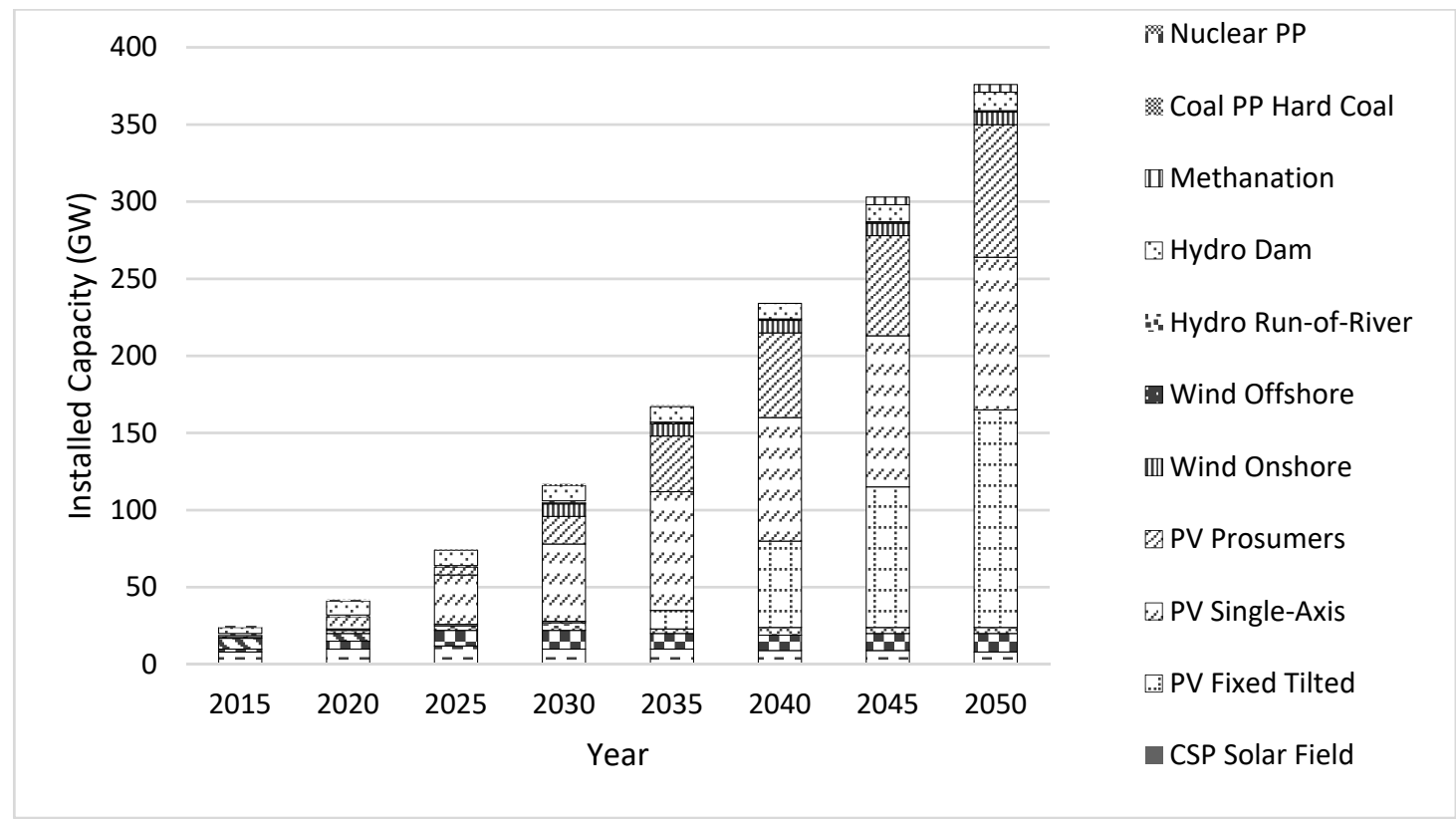

(a)

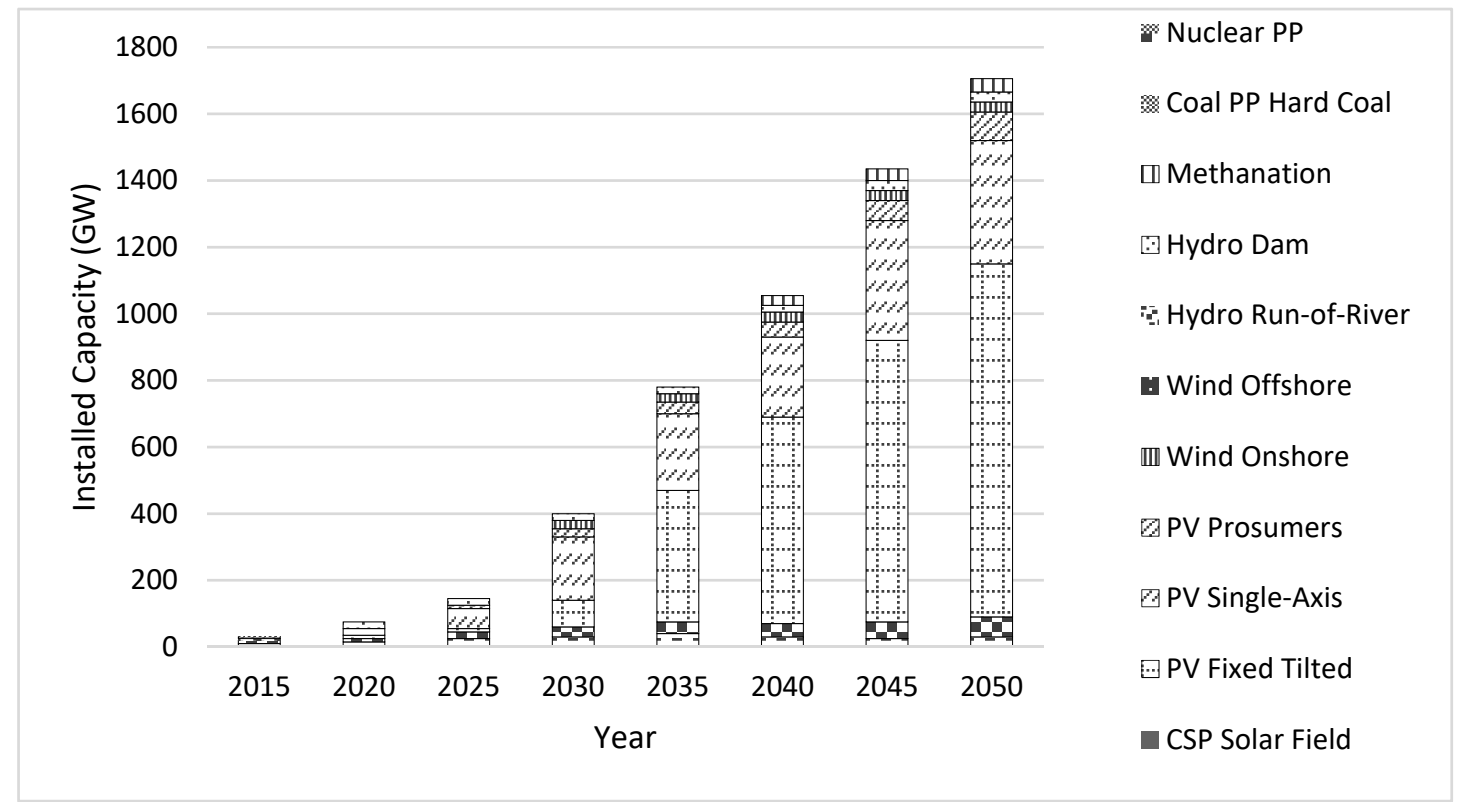

(b)

Figure 16. Collective installed capacity from all of the renewable resources by 2050 for (a) the power and (b) integrated scenarios.

During 2015-2016, 300 MW of solar energy projects has been added to the NTDC's network. For a rise of $204 \mathrm{GWh}$ for the energy generated through solar through this period, the total energy through solar has been recorded to be $230 \mathrm{GWh}$ [21]. 
Table 12. Solar PV projects under development with their capacities and estimated COD.

\begin{tabular}{|c|c|c|c|c|}
\hline Sr. No. & Company & $\begin{array}{l}\text { Project } \\
\text { Capacity }\end{array}$ & Location & Expected COD \\
\hline 1 & Access Solar Pvt. Ltd. & 11.52 & Pind Dadan Khan, Punjab & March-2018 \\
\hline 2 & Bukhsh Solar (Pvt.) Ltd. & 10 & Pind Dadan Khan, Punjab & December-2017 \\
\hline 3 & Integrated Power Solution & 50 & Nooriabad, Sindh & June-2018 \\
\hline 4 & Jafri \& Associates & 50 & Nooriabad, Sindh & June-2018 \\
\hline 5 & Solar Blue Pvt. Ltd. & 50 & Nooriabad, Sindh & June-2018 \\
\hline 6 & Safe Solar Power Pvt. Ltd. & 10 & Bahawalnager, Punjab & December-2017 \\
\hline 7 & Access Electric Pvt. Ltd. & 10 & Pind Dadan Khan, Punjab & March-2018 \\
\hline 8 & R.E. Solar I Pvt. Ltd. & 20 & Dadu, Sindh & March-2018 \\
\hline 9 & R.E. Solar II Pvt. Ltd. & 20 & Dadu, Sindh & March-2018 \\
\hline 10 & Jan Solar (Pvt.) Ltd. & 10 & Sultanabad, RYK, Punjab & March-2018 \\
\hline 11 & Janpur Energy Limited & 10 & Mehmood Kot, Muzafargarh, Punjab & March-2018 \\
\hline 12 & Blue Star Hydel Pvt. Ltd. & 1 & $\begin{array}{c}\text { Pind Dadan Khan, District Jehlum, } \\
\text { Punjab }\end{array}$ & December-2017 \\
\hline 13 & Blue Star Electric Pvt. Ltd. & 1 & $\begin{array}{l}\text { Pind Dadan Khan, District Jehlum, } \\
\text { Punjab }\end{array}$ & December-2017 \\
\hline 14 & Siddiqsons Energy Karachi & 50 & Chakwal, Punjab & March-2018 \\
\hline 15 & Harappa Solar (Pvt.) Ltd. & 18 & Harappa, District Sahiwal, Punjab & December-2017 \\
\hline 16 & AJ Power (Pvt.) Ltd. & 12 & Adhi Kot, District Khushab, Punjab & December-2017 \\
\hline 17 & $\begin{array}{c}\text { Adamjee Power Generation } \\
\text { Pvt. Ltd. }\end{array}$ & 10 & Norsar, Bahawalnager, Punjab & December-2018 \\
\hline 18 & Forshine (Pakistan) & 50 & Gharo, Thatta, Sindh & June-2019 \\
\hline 19 & ET Solar (Pvt.) Ltd. & 50 & $\begin{array}{c}\text { Fateh Jhang Road, District Attock, } \\
\text { Punjab }\end{array}$ & December-2018 \\
\hline 20 & ET Solar (Pvt.) Ltd. & 25 & Gharo, Thatta, Sindh & December-2018 \\
\hline 21 & Act Solar (Pvt.) Ltd. & 50 & Sindh Province & December-2018 \\
\hline 22 & Crystal Energy (Pvt.) Ltd. & 2 & Sambrayal, District Sialkot, Punjab & May-2019 \\
\hline 23 & Asia Petroleum Ltd. & 30 & Punjab Province & December-2018 \\
\hline 24 & First Solar (Pvt.) Ltd. & 2 & $\begin{array}{l}\text { Makhayal, Kalarkahar, District } \\
\text { Chakwal, Punjab }\end{array}$ & December-2018 \\
\hline
\end{tabular}

\subsection{Geothermal Power Source}

In the world's primary energy consumption, only a small portion is contributed by geothermal energy i.e., less than $1 \%$. In 2015, the total geothermal capacity of the world rose to $13.2 \mathrm{GW}$ due to an additional $315 \mathrm{MW}$ of capacity installed in 2018. The geographical locations of geothermal-based power plants, which produce $72 \%$ of the total global geothermal capacity, are along Pacific Rim hot spot features or the tectonic plate borders. An unbalanced percentage of $43 \%$ for installed capacity is located on regions or island nations, and is suitable for applications such as heating, power production, and the storage of heat in ambient situations [20]. Figure 17 shows the geothermal installed capacity around the world [89].

Geological studies suggest that since Pakistan is located at a junction of tectonic plates, it has plentiful resources of geothermal energy with a tendency to be utilized to keep the energy supply on par with the demand of the country. This opinion is based on the proper buildout of alteration zones and fumaroles across the country, the presence of hot springs, and the signs of quaternary volcanism [90]. Unfortunately, there is no installed geothermal power plant in the country, making this sector the least exploited among all of the other energy resources. 


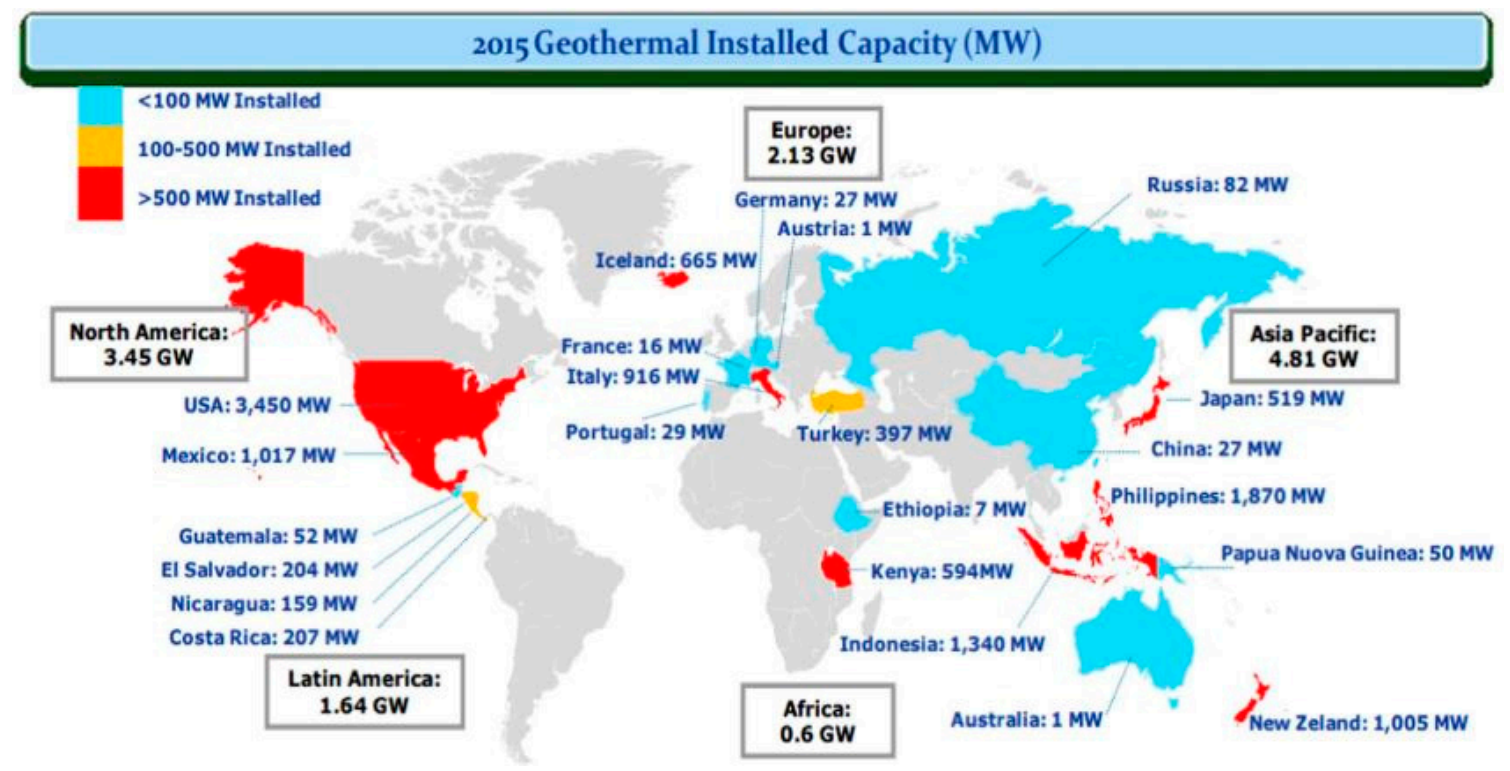

Figure 17. Geothermal installed capacity around the world. $(1.96 ", 1.96)$.

In Pakistan, geothermal areas are classified into three main zones: the Chaghi volcanic arc, Himalayan collision zone, and Indus basin margin zone, as seen in Figure 18 [91]. The surface hot water of the Himalayan collision zone has a temperature of $90^{\circ} \mathrm{C}$. In the southernmost area of foredeep, the gas and Giandari oil reservoir have a peculiarly elevated thermal gradient i.e., $4.1^{\circ} \mathrm{C} / 100 \mathrm{~m}$. Similarly, high gradients of about 3.0-3.49/100 m have been recorded at the gas and oil wells of Mart and Sui. Thermal springs are present in Uch and GarmAb, which are located at the base of Bakkur, Taunsa, Mari Hills, and ZindaPir, and can serve as geothermal energy. Talking about the Indus basin zone, the gas and oil fields of Lakhra in the south Kirthar zone also shows a high thermal gradient of $3.3^{\circ} \mathrm{C} / 100 \mathrm{~m}$, while those of Sari and Karachi have a geothermal gradient of $3{ }^{\circ} \mathrm{C} / 100 \mathrm{~m}$. A cluster of hot springs is present in ManghoPir and the Karsaaz area of Karachi, presenting a potential of geothermal energy. The volcanic arc in the Chaghi zone has less thermal springs than the other two zones, which are linked with the Sinjrani volcanics of Koh-i-Sultan [91,92]. Depending upon the temperature ranges, geothermal resources can be divided into categories for application, which are shown in Table 13 [93].

As mentioned earlier, Pakistan has not exploited much of its geothermal potential. Less than 10\% of hot springs waters are utilized for residential and commercial purposes on a very small scale. All of the remaining spring water becomes a part of rivers and the sewer system without being used [94]. The apparent reason for not capitalizing on the geothermal resources in Pakistan is lack of data [92], which can be countered with detailed geological analysis by the use of new technologies. Currently, research is being done in the domain of Hard Dry Rock (HDR) geothermal energy, which has shown promising results, but still more detailed geoscientific information is required in order to implement it [95]. 


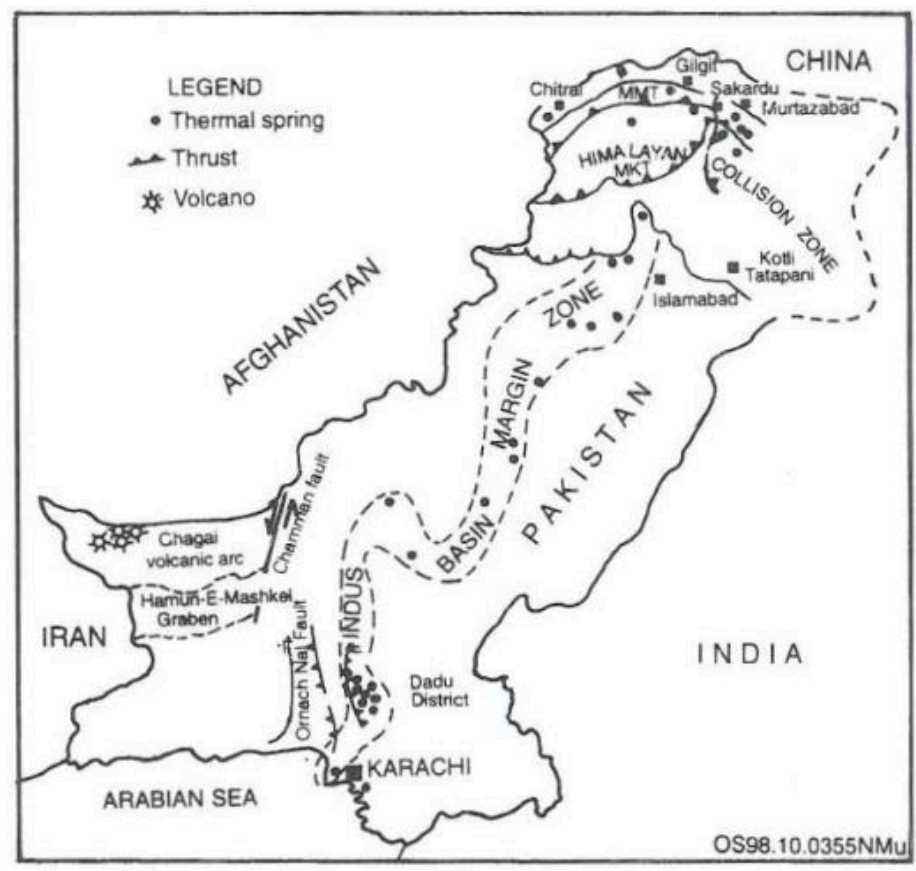

Figure 18. Map showing areas of geothermal activity and some important geological and tectonic features of Pakistan. $\left(1.96^{\prime \prime}, 1.96\right)$.

Table 13. Applications for the geothermal resources of Pakistan.

\begin{tabular}{|c|c|c|c|}
\hline Location & Resource Type & Temperature & Applications \\
\hline Chaghi & Hydro Geothermal & $200-300^{\circ} \mathrm{C}$ & $\begin{array}{l}\text { - } \quad \text { Flash and dry steam power plant } \\
\text { - Hydrogen production }\end{array}$ \\
\hline Mutazabad & Hydro Geothermal & $185-230^{\circ} \mathrm{C}$ & $\begin{array}{ll}\text { - } & \text { Binary power plant } \\
\text { - } & \text { Ethanol, biofuels production }\end{array}$ \\
\hline Tatta Pani, Tato, Kotli & Hydro Geothermal & $100-200^{\circ} \mathrm{C}$ & $\begin{array}{ll}\text { - } & \text { Binary power plant } \\
\text { - } & \text { Fabric drying } \\
\text { - } & \text { Refrigeration and ice making } \\
\text { - } & \text { Cember drying } \\
\text { - } & \text { Heating, ventilation and air } \\
& \text { conditioning HVAC } \\
\text { - } & \text { Pulp drying }\end{array}$ \\
\hline Karachi & Hydro Geothermal & $70-145^{\circ} \mathrm{C}$ & $\begin{array}{l}\text { - } \quad \text { Pulp and paper processing } \\
\text { - } \quad \text { Fruit and vegetable drying } \\
\text { - } \quad \text { Soft drink carbonation } \\
\text { - } \quad \text { Green housing } \\
\text { - } \quad \text { Food processing } \\
\text { - Concrete block curing }\end{array}$ \\
\hline Chakwal & Hydro Geothermal & $60-90^{\circ} \mathrm{C}$ & $\begin{array}{ll}\text { - } & \text { Aqua culture } \\
\text { - } & \text { Mushroom culture } \\
\text { - } & \text { Biogas production } \\
\text { - } & \text { Heat pump HVAC }\end{array}$ \\
\hline
\end{tabular}

\subsection{Biomass Power Source}

Biomass, being the fourth biggest global energy resource, offers $10 \%$ of the world's primary energy, and can be gaseous, liquid, or solid phase. It comprises various crop remains from agriculture, forest residues, ordure, and industrial and municipal waste. In 2011, the total installed capacity of biomass-based energy rose to $72 \mathrm{GW}$ due to a $9 \%$ increase in electricity generation [96]. 
Pakistan can take advantage of being a large producer of many crops such as sugarcane, wheat, rice, cotton, oilseeds, grains, and pulses, by extracting biomass and biofuels from their leftovers, while in parallel providing for the food demand without any extra cost. Also, Pakistan has an immense capability of bagasse utilization for power production, since the country is the fifth largest sugarcane producer [97]. Unfortunately, this beneficial and existing renewable resource has not yet been optimally used in Pakistan. According to statistics performed by the United Nations in 2015, bagasse production per annum was 19,886 metric tons in Pakistan [84].

During 2015-2016, there was an increase of about $63 \mathrm{MW}$ in the generation of power from bagasse-based power plants, for a total of about $146 \mathrm{MW}$ in the NTDC's system. The energy generated by bagasse-based power plants during the FY 2015-2016 has been noted as 547 GWh [21].

\section{Biomass Resources Potential in Pakistan}

Biomass potential has been endorsed worldwide such that many countries have implemented and used biomass for energy production. Table 14 shows biomass resources, their possible utilization, and technologies for conversions. A comparison between the biomass potential of various countries and production has been made in Table 15.

Table 14. Biomass resources, their possible utilization, and technologies for conversions.

\begin{tabular}{|c|c|c|c|c|}
\hline Biomass Resource & Present Utilization & $\begin{array}{l}\text { Potential } \\
\text { Conversion } \\
\text { Technology }\end{array}$ & $\begin{array}{l}\text { Potential End-Use as } \\
\text { an Energy Product }\end{array}$ & Reference \\
\hline Wheat straw & $\begin{array}{l}\text { Paper products, domestic } \\
\text { heating }\end{array}$ & Gasification & $\begin{array}{l}\text { Off-grid electricity } \\
\text { generation, Synthetic } \\
\text { Natural Gas SNG }\end{array}$ & [98] \\
\hline Rice husk & $\begin{array}{l}\text { Pet food fiber, making of } \\
\text { activated carbon, fuel }\end{array}$ & $\begin{array}{l}\text { Gasification and } \\
\text { combustion }\end{array}$ & $\begin{array}{l}\text { substitute household } \\
\text { energy, off-grid energy } \\
\text { generation }\end{array}$ & [99] \\
\hline Bagasse & $\begin{array}{l}\text { fuel and bioethanol } \\
\text { production }\end{array}$ & $\begin{array}{l}\text { Fermentation and } \\
\text { hydrolysis }\end{array}$ & Renewable motor fuel & [100] \\
\hline $\begin{array}{l}\text { Poultry/cow } \\
\text { manure }\end{array}$ & $\begin{array}{l}\text { Biogas and fertilizer } \\
\text { production }\end{array}$ & $\begin{array}{l}\text { Composting, } \\
\text { fermentation }\end{array}$ & $\begin{array}{l}\text { Biogas, household fuel, } \\
\text { methane }\end{array}$ & [97] \\
\hline $\begin{array}{l}\text { Forestry residues } \\
\text { and wood }\end{array}$ & $\begin{array}{c}\text { Fuel, biomass production, } \\
\text { fertilizer }\end{array}$ & $\begin{array}{l}\text { Grinding and } \\
\text { saw-milling }\end{array}$ & Fuel wood & [101] \\
\hline $\begin{array}{l}\text { Municipal solid } \\
\text { waste }\end{array}$ & $\begin{array}{l}\text { Strengthening concrete, } \\
\text { Bottom ash production }\end{array}$ & $\begin{array}{l}\text { Pyrolysis, sieving, } \\
\text { combustion }\end{array}$ & $\begin{array}{l}\text { Methanol, methane } \\
\text { and syn gas } \\
\text { production }\end{array}$ & [15] \\
\hline
\end{tabular}

Table 15. Biomass production and energy potential in various countries.

\begin{tabular}{ccccc}
\hline Sr. No & Countries & Biomass Production Mt $\mathbf{~ r r}^{-\mathbf{1}}$ & $\begin{array}{c}\text { Biomass Energy } \\
\text { Potential }\end{array}$ & References \\
\hline 1 & Nigeria & 145.62 & $1958.94{ }^{*} \mathrm{PJ}$ & $16,920 \mathrm{ktoe}$ \\
2 & Turkey & $526(2010)$ & 16,920 & {$[102]$} \\
3 & Malaysia & 160 & 14,888 & {$[22]$} \\
4 & China & $57.4 *$ TWh & 3447 estimated value & {$[104,105]$} \\
5 & Bangladesh & 80.4 & $91,772{ }^{*} \mathrm{ktoe}$ & {$[106]$} \\
6 & Pakistan & $95.3 \mathrm{KWh}$ billion & $313.14{ }^{*} \mathrm{MCM}$ & {$[101,107]$} \\
7 & Jordan & 5.83 & $573{ }^{*} \mathrm{EJ}$ & {$[108]$} \\
8 & World & $493{ }^{*} \mathrm{TWh}$ & {$[29,107,109]$} \\
\hline
\end{tabular}

${ }^{*}$ PJ: Petajoule, ${ }^{*}$ TWh: terawatt-hour, ${ }^{*}$ Ktoe: kilotonne of oil equivalent, ${ }^{*} \mathrm{MCM}$ : Million cubic meters, ${ }^{*} \mathrm{EJ}:$ Exajoule.

Pakistan has an abundant amount of waste produced in the form of bagasse, poultry waste, and municipal waste. This paper will highlight the importance of the potential usage of these wastes as biomass energy sources [110-112]. 


\subsection{Bagasse}

The industrial refinement process of sugarcane produces by-products along with sugar that include molasses, press cake, and bagasse, which make up $40 \%$ of the weight out of the total crushed sugarcane. It has been observed that each ton of processed sugarcane produces $200-300 \mathrm{~kg}$ of bagasse $[113,114]$. Therefore, to cope with the energy requirements and produce surplus electricity, a continuous refinement process is desirable, thereby contributing as a renewable resource $[110,111,115]$. Generally, 0.173 tons of oil (about $\$ 80 /$ ton) and 0.263 tons of coal (about $\$ 55 /$ ton) are comparable to one ton (about $\$ 15 /$ ton) of bagasse [116]. The cogeneration plant is often located near the sugar industry to save the environment from dust pollution that could otherwise be caused during transportation. Relative to the combustion of fossil fuels, cogeneration effectively lowers the production of greenhouse gases. It is advisable that bagasse is used for the cogeneration because if it is not used, it starts decaying by itself and producing methane gas, which is 27 degrees more hazardous for the ozone layer than $\mathrm{CO}_{2}$ [117].

Pakistan is a large sugarcane producer, with several mills of sugar located in Punjab and Sindh. Pakistan has a potential of about $3000 \mathrm{MW}$ or even more power production from sugar mills, as shown in Figure 19 [83]. Unfortunately, the available bagasse resource has not been optimally employed due to technological constraints such as the low-pressure boilers and low-efficiency steam turbines that bound the sufficient amount of electricity production, so it can only meet the mill's own demand [118].

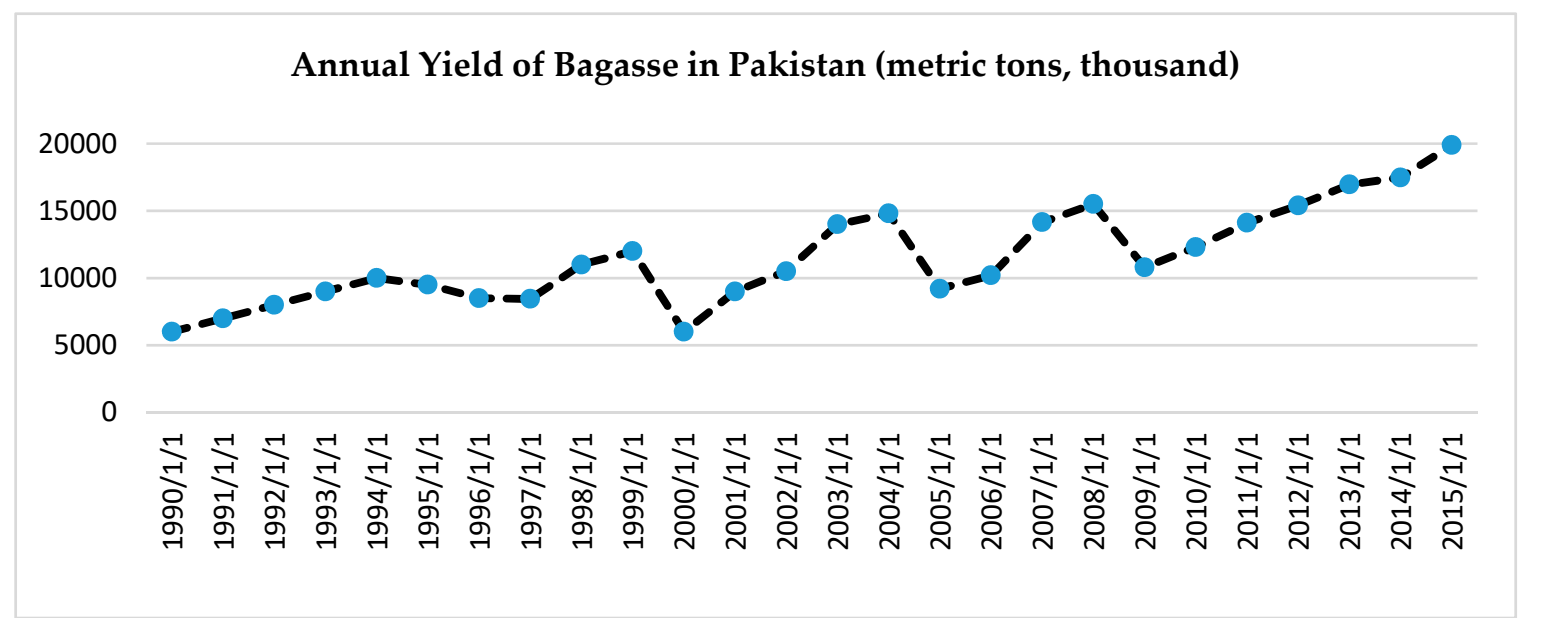

Figure 19. Bagasse yield per annum in Pakistan from 1990-2015.

Ventures for biomass visions in Pakistan have been promised by PCRET [14]. The significance and necessity of bagasse-based fuels in the country have also been emphasized by the AEDB [119]. Some crucial steps have been taken by the National Electric Power Regulatory Authority (NEPRA) to determine the tariff for future power projects based on bagasse-based cogeneration to intrigue customers and investors [120].

\subsection{Poultry Waste}

Pakistan has a well-established industry of poultry [112]. The GoP renounced sales and income tax import amenities, making the poultry business successfully operational in the market. As of now, the poultry industry shares $1.26 \%$ and $5.76 \%$ of the complete gross domestic product (GDP) and total production from agriculture, respectively [121].

To date, Pakistan has more than 25,000 poultry farms striving to fulfil the country's protein demand in the forms of eggs, meat, and for the further reproduction of poultry animals, and this number is continuously rising. Consequently, a tremendous volume of poultry waste is left over [121,122]. Organic matter from poultry waste is not consumed in any productive way, and is usually pronounced as waste [123], but in reality, it is an advantageous source of energy with vast 
applications [124-127]. Biogas generation can be carried out with organic matter such as feathers, blood, manure, and spilled feed, which can be utilized for electricity generation $[128,129]$. The anaerobic digestion process of poultry waste produces biogas $[123,130]$. Anaerobic digestion also produces a nutrient rich by-product called biodigestate, which can be consumed as a fertilizer [131].

Pakistan can make use of the factory's process flow diagram to generate power using poultry waste, as shown in Figure 20. From 2011 to 2015, the amount of poultry waste produced has been reported in Figure 21. A huge amount of manure, feathers, feet, blood, spilled feed, and other inedible organs are disposed of. Proper poultry waste management using biomass energy conversion technologies could guarantee approximately $10,335 \mathrm{~m}^{3}$ of biogas, which in turn would be capable of generating about $300 \mathrm{MWh}$ per day. The conversion process from poultry waste to biogas also leaves biodigestate as a by-product, which could serve as a biofertilizer [132].

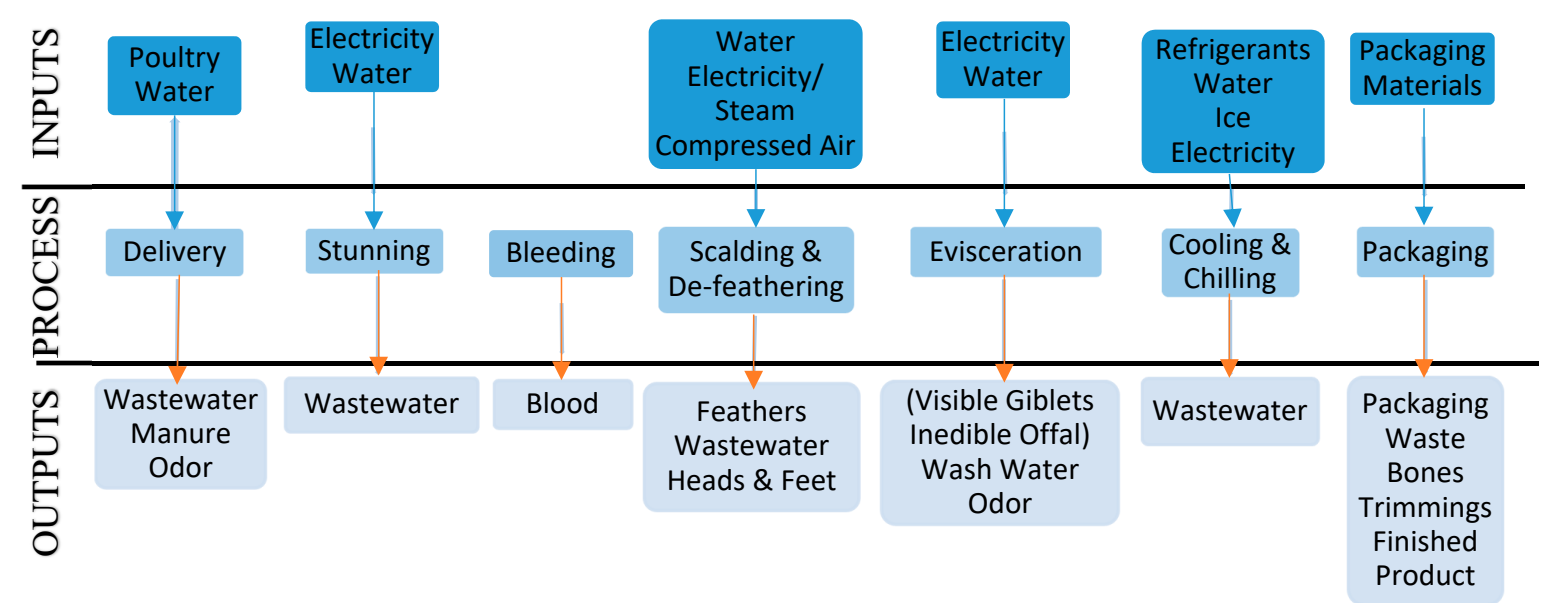

Figure 20. Factory's process flow diagram to generate power using poultry waste.
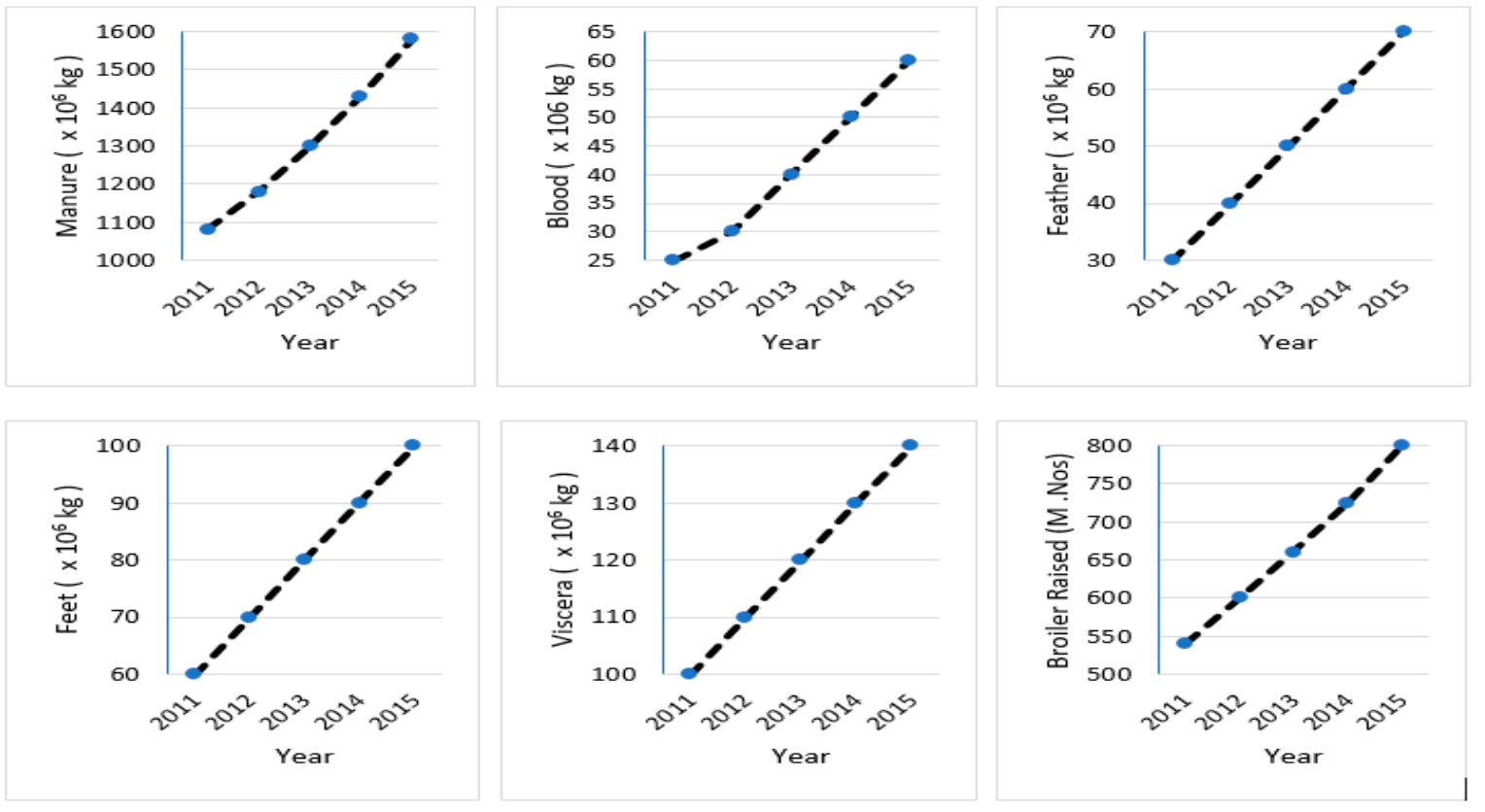

Figure 21. Waste produced in the poultry farms from 2011 to 2015.

\subsection{Municipal Waste}

Anything that is regarded as useless, worthless, or in excess is called waste. All of the waste gathered from domestic, commercial, and industrial sources by private and public authorities is called municipal solid waste (MSW) [133]. A waste-management process and the relevant 
systems are organized programs that are established for the disposal of waste, recycling, reuse, composting, and incineration. They are also an important way to conserve resources and protect the environment [134]. In underdeveloped and developing countries, MSW is an extremely ignored factor [135]. Environmental pollution and health hazards are a result of the poor management of waste [136]. The burden of emissions and resources depletion that is placed on the environment can be highly reduced by appropriate waste management strategies $[137,138]$. Biogenic MSW is considered a source for renewable energy by the United States (US) Environmental Protection Agency because it would otherwise be dumped into landfills [139].

In Pakistan, millions of tons of diverse kinds of wastes are produced annually that pose health and other environmental hazards. Even though the private and public sectors have been long conscious of the waste disposal crisis, they are unacquainted with the possible use of MSW for electricity production to reduce the country's power crisis. In Pakistan, a significant barrier to the promotion of such renewable energy projects is the deprivation of the suitable recognition of the management of diverse waste types and associated power production technologies [140]. For 2014 and 2016, the amount of waste produced in Pakistan's foremost cities are shown in Table 16, demonstrating that a gross total of 32.3 megatons (MT) per year is generated [141].

Table 16. Quantity of municipal solid waste (MSW) generated in the major cities of Pakistan in 2014 and 2016.

\begin{tabular}{|c|c|c|c|c|c|c|}
\hline \multirow[b]{2}{*}{ City Corporation } & \multicolumn{3}{|c|}{2014} & \multicolumn{3}{|c|}{2016} \\
\hline & $\begin{array}{c}\text { Population } \\
\text { (Million) }\end{array}$ & $\begin{array}{c}\text { Generation } \\
\text { Rate } \\
\text { (kg/Capita/Day) }\end{array}$ & $\begin{array}{c}\text { Total } \\
\text { Quantity } \\
\text { (MT/Year) }\end{array}$ & $\begin{array}{l}\text { Population } \\
\text { (Million) }\end{array}$ & $\begin{array}{c}\text { Generation } \\
\text { Rate } \\
\text { (kg/Capita/Day) }\end{array}$ & $\begin{array}{c}\text { Total } \\
\text { Quantity } \\
\text { (MT/Year) }\end{array}$ \\
\hline Karachi & 14 & 0.572 & 2.92 & 22.825 & 0.572 & 4.765 \\
\hline Lahore & 0 & 0.151 & 0.507 & 10.335 & 0.75 & 2.835 \\
\hline Faisalabad & 2.7 & 0.53 & 0.522 & 3.675 & 0.45 & 0.604 \\
\hline Hyderabad & 9.2 & 0 & 0 & 2.99 & 0.8 & 0.873 \\
\hline Peshawar & 0 & 0 & 0 & 1.785 & 0.38 & 0.248 \\
\hline Gujranwala & 1.85 & 1.08 & 0.73 & 2.195 & 1.08 & 0.865 \\
\hline Quetta & 0 & 0 & 0 & 1.14 & 0.378 & 0.157 \\
\hline Multan & 2.06 & 0.53 & 0.402 & 1.95 & 1.53 & 0.377 \\
\hline Sialkot & 0 & 0 & 0 & 0.58 & 0.313 & 0.067 \\
\hline Islamabad & 0 & 0 & 0 & 0.74 & 0.53 & 0.143 \\
\hline Rawalpindi & 2.5 & 0.21 & 0.192 & 1.77 & 0.21 & 0.136 \\
\hline Kharian & 0.035 & 2.57 & 0.033 & 0 & 0 & 0 \\
\hline Lala Musa & 1 & 0.027 & 0.01 & 0 & 0 & 0 \\
\hline Sukkur & 0 & 0 & 0 & 0.585 & 0.45 & 0.096 \\
\hline Total & 33.345 & 5.67 & 5.316 & 50.59 & 6.443 & 11.166 \\
\hline Remaining urban area & 0 & 0 & 0 & 23.11 & 0.84 & 7.086 \\
\hline Rural area & 0 & 0 & 0 & 114.32 & 0.30 & 12.518 \\
\hline Subtotal & 33.345 & 5.67 & 5.316 & 188.02 & 7.583 & 30.764 \\
\hline Hazardous waste & & 0 & 0 & 0 & 0 & 1.538 \\
\hline Gross total & & & 5.316 & & & 32.3 \\
\hline
\end{tabular}

Figure 22 shows that the use of biochemical processes of MSW will cause a reduction from $0.1 \%$ to $0.03 \%$ in the share of imported electricity [50]. The energy attained by the biochemical processing of MSW may contribute up to $0.07 \%$. The thermal chemical processing of MSW contributes $0.34 \%$, whereas the contribution of gas, oil, nuclear and hydro, and coal are $46.74 \%, 34.34 \%, 13.14 \%$, and $5.34 \%$, respectively, as shown in Figure 22. The share of supply from gas, nuclear and hydro, oil, and coal can be reduced to $0.13 \%, 0.17 \%, 0.45 \%$, and $1.11 \%$, respectively, with the treatment of MSW with thermal chemical processing. The dependency on imported energy will be reduced by using energy from treated MSW [141,142]. Hence, an improved environment and development of the economy also rely on waste to energy conversion, along with other factors. 


\begin{tabular}{|c|c|c|c|c|c|c|}
\hline \multirow{8}{*}{\multicolumn{2}{|c|}{ 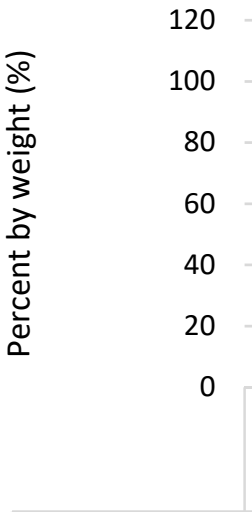 }} & & & & & \\
\hline & & मिख & 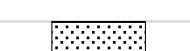 & a & -_-_-- & $=--$ \\
\hline & & & & & $-=$ & $=-=-1$ \\
\hline & & & & & - & \\
\hline & & 3 & $\because \div$ & $\therefore 3$ & 383 & को \\
\hline & & & & & $8 \%$ & 838 \\
\hline & & 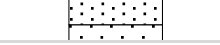 & $\because \because \because$ & $\because \because \because$ & $\vdots \vdots \vdots \vdots \vdots \vdots$ & $\vdots \vdots \vdots \vdots \vdots \vdots$ \\
\hline & & $\begin{array}{c}\text { Present energy } \\
\text { consumption of } \\
\text { Pakistan }\end{array}$ & $\begin{array}{l}\text { Present study } \\
\text { (Bio-Ch.P) }\end{array}$ & $\begin{array}{l}\text { Present study } \\
\text { (Th-Ch.P) }\end{array}$ & 2015 & 2013 \\
\hline & I MSW & 0 & 0.07 & 0.34 & 0 & 0 \\
\hline & $\square$ Biomass & 0 & 0 & 0 & 20 & 42 \\
\hline & a Imported elec. & 0.1 & 0.03 & 0 & 0 & 0 \\
\hline & $\because$ Gas & 46.8 & 46.8 & 46.74 & 23 & 16 \\
\hline & Hydro/Nuclear & 13.2 & 13.2 & 13.14 & 29 & 22 \\
\hline & Oil & 34.4 & 34.4 & 34.34 & 28 & 20 \\
\hline & ๑Coal & 5.4 & 5.4 & 5.34 & 0 & \\
\hline
\end{tabular}

Figure 22. Biomass/MSW contribution in total energy supply.

\section{Current and Future Scenarios of Biomass Applications in Pakistan}

This section discusses the current and future elements involved in the biomass applications in Pakistan. Different energy consumption sectors have been discussed in terms of biomass power source applications.

\subsection{Power Production}

Biomass is considered to have great capabilities as an important and available renewable energy source for developed, developing, and underdeveloped cTuntries. Pakistan is still in the experimental stage for using biomass for power production. In the NTDC's system, an increase in power generation of about $63 \mathrm{MW}$ for a total of about $146 \mathrm{MW}$ from bagasse-based power plants has been observed during 2015-2016, having 547 GWh of energy. Three companies with an aggregate capacity of $99.0 \mathrm{MW}$ applied during this span for the complete approval of an upfront tariff for bagasse-based power production schemes, as mentioned in Table 17 [21].

Pakistan lacked any biomass/bagasse-based power plants until 2014. Power stations, namely Jamal Din Wali-II, Jamal Wali-III, and Rahim Yar Khan Mills, which are located in Rahim Yar Khan (Punjab), started their operation from 2015, and Chiniot Power, which is located in Chiniot (Punjab), started its operation from 2016. The installed capacity in MW and electricity generation in gigawatt hours GWh, as recorded on 30 June 2016, have been listed in Table 18 [21].

According to the NEPRA 2016 state of industry report, the estimated costs and commercial operation dates (COD) of in-operation and under construction biomass energy projects are shown in Table 19, whereas those for future biomass/bagasse projects are shown in Table 20, in which most of the projects are in the Letter of Intent stage, and will probably be completed by the end of 2018 [21]. According to the Renewable Energy Policy of 2006, various electricity generation projects involving biomass/bagasse were given licenses for generation, keeping in view their fuel type and technology. Table 21 shows a list of generation licensees for bagasse/biomass. These projects are majorly based on bagasse fuel, and their technologies make use of steam turbines. In Pakistan, the companies that are captive power producers (CPPs) using biomass/bagasse are 35 in number. Shakarganj Energy (Pvt.) Limited is the only Isolated Generation Company (IGC) for energy production using biomass [21]. 
Table 17. Upfront tariff for new bagasse-based cogeneration projects in Pakistan.

\begin{tabular}{clc}
\hline Sr. No. & \multicolumn{1}{c}{ Company } & Installed Capacity (MW) \\
\hline 1 & Chanar Energy Limited & 22 \\
2 & Al-Moiz Industries Limited & 36 \\
3 & Thal Industries Corporation Limited & 41 \\
\hline \multicolumn{2}{c}{ Total } \\
\hline
\end{tabular}

Table 18. Installed capacity (MW) and electricity generation in gigawatt hours (GWh) of bagasse/biomass power stations as of 30 June 2016.

\begin{tabular}{|c|c|c|c|c|c|c|c|c|c|c|c|c|}
\hline \multirow{2}{*}{ Power Station } & \multicolumn{2}{|c|}{ Fuel } & \multicolumn{5}{|c|}{ Installed Capacity (MW) } & \multicolumn{5}{|c|}{ Electricity Generation (GWh) } \\
\hline & Primary & Alternate & 2012 & 2013 & 2014 & 2015 & 2016 & 2012 & 2013 & 2014 & 2015 & 2016 \\
\hline $\begin{array}{l}\text { Jamal Din } \\
\text { Wali-II }\end{array}$ & \multicolumn{2}{|c|}{ Bagasse + Biomass } & 0 & 0 & 0 & 26 & 26 & 0 & 0 & 9 & 163 & 159 \\
\hline $\begin{array}{l}\text { Jamal Din } \\
\text { Wali-III }\end{array}$ & \multicolumn{2}{|c|}{ Bagasse + Biomass } & 0 & 0 & 0 & 27 & 27 & 0 & 0 & 0 & 132 & 151 \\
\hline $\begin{array}{l}\text { Rahim Yar } \\
\text { Khan Mill }\end{array}$ & Bagasse & Bagasse & 0 & 0 & 0 & 30 & 30 & 0 & 0 & 0 & 32 & 77 \\
\hline Chiniot Power & Bagasse & Bagasse & 0 & 0 & 0 & 0 & 63 & 0 & 0 & 0 & 0 & 169 \\
\hline
\end{tabular}

Table 19. Status of existing projects (in operation and under construction).

\begin{tabular}{cccccc}
\hline Sr. No. & Name of Project & $\begin{array}{c}\text { Capacity } \\
\text { (MW) }\end{array}$ & $\begin{array}{c}\text { COD/Expected } \\
\text { COD }\end{array}$ & $\begin{array}{c}\text { Estimated Cost } \\
\text { (US \$ Million) }\end{array}$ & Status \\
\hline 1. & JDW Sugar Mills Limited & 26.35 & June 2014 & 26.26 & Operational \\
$\quad \begin{array}{c}\text { (Unit-II) } \\
2 .\end{array}$ & JDW Sugar Mills Limited & 26.35 & October 2014 & 26.26 & Operational \\
3. & (Unit-III) & 62.40 & November 2014 & 62.19 & Operational \\
4. & Chiniot Power Limited & 30 & March 2015 & 29.90 & $\begin{array}{c}\text { Operational } \\
5 .\end{array}$ \\
Hamza Sugar Mills Limited & 15 & - & 14.95 & Under Construction \\
\hline
\end{tabular}

Table 20. Future biomass/bagasse-based projects.

\begin{tabular}{cccccc}
\hline Sr. No. & Name of Project & $\begin{array}{c}\text { Capacity } \\
\text { (MW) }\end{array}$ & $\begin{array}{c}\text { COD/Expected } \\
\text { COD }\end{array}$ & $\begin{array}{c}\text { Estimated Cost } \\
\text { (US \$ Million) }\end{array}$ & Status \\
\hline 1. & Layyah Sugar Mills Limited & 41 & 2017 & 40.86 & EPA/IA Signed \\
2. & Alliance Sugar Mills Limited & 30 & 2017 & 29.90 & LOI Stage \\
3. & Safina Sugar Mills Limited & 20 & 2017 & 19.93 & LOI Stage \\
4. & Almoiz Industries Limited & 36 & 2017 & 35.88 & LOI Stage \\
5. & Etihad Power Generation Limited & 76.40 & 2017 & 76.13 & LOI Stage \\
6. & Shahtai Sugar Mills Limited & 32 & 2017 & 31.89 & LOI Stage \\
7. & Chinar Energy Limited & 22 & 2017 & 21.93 & LOI Stage \\
8. & RYK Energy Limited & 25 & 2018 & 24.92 & LOI Stage \\
9. & Sheikhoo Power Limited & 30 & 2018 & 29.90 & LOI Stage \\
10. & Indus Energy Limited & 31 & 2018 & 30.89 & LOI Stage \\
11. & Hamza Sugar Mills Limited (Unit-II) & 30 & 2018 & 29.90 & LOI Stage \\
12. & Hunza Power (Pvt.) Limited & 49.80 & 2018 & 49.63 & LOI Stage \\
13. & Bahawalpur Energy Limited & 31.20 & 2018 & 31.09 & LOI Stage \\
14. & Mirpur Khas Energy Limited & 26 & 2018 & 25.91 & LOI Stage \\
15. & Faran Power (Pvt.) Limited & 26.50 & 2018 & 26.45 & LOI Stage \\
16. & Ittefaq Power (Pvt.) Limited & 31.20 & 2018 & 31.09 & LOI Stage \\
17. & Mehran Energy Limited & 26.50 & 2018 & 26.41 & LOI Stage \\
18. & Lumen Energia & 12 & 2018 & 22.62 & LOI Stage \\
\hline
\end{tabular}


Table 21. List of generation licensees bagasse/biomass power projects under the renewable energy policy of 2006.

\begin{tabular}{|c|c|c|c|c|}
\hline Sr. No. & Company and Location & $\begin{array}{l}\text { Installed Capacity } \\
\text { (MW) }\end{array}$ & Fuel Type & Technology \\
\hline 1. & $\begin{array}{l}\text { SSID Bioenergy Limited, Mirpur Khas, } \\
\text { Sindh }\end{array}$ & 12.00 & Bagasse & Steam Turbine \\
\hline 2. & $\begin{array}{c}\text { Lumen Energia (Pvt.) Limited, Jhang, } \\
\text { Punjab }\end{array}$ & 12.00 & Biomass & Steam Turbine \\
\hline 3. & Shakarganj Mills Limited-II, Jhang, Punjab & 12.00 & Bagasse + Furnace Oil & Steam Turbine \\
\hline 4. & $\begin{array}{l}\text { Pak-Ethanol (Pvt.) Limited, Tando } \\
\text { Muhammad Khan, Sindh }\end{array}$ & 9.132 & Biogas & Gas Engine \\
\hline 5. & $\begin{array}{l}\text { JDW Sugar Mills Limited, Rahim Yar Khan, } \\
\text { Punjab }\end{array}$ & 26.35 & Bagasse + Biomass & Steam Turbine \\
\hline 6. & JDW Sugar Mills Limited, Ghotki, Sindh & 26.35 & Bagasse + Biomass & Steam Turbine \\
\hline 7. & Chiniot Power Limited, Chiniot, Punjab & 62.40 & Bagasse & Steam Turbine \\
\hline 8. & $\begin{array}{c}\text { RYK Mills Limited, Rahim Yar Khan, } \\
\text { Punjab }\end{array}$ & 30.00 & Bagasse & Steam Turbine \\
\hline 9. & $\begin{array}{c}\text { Hamza Sugar Mills Limited, Rahim Yar } \\
\text { Khan, Punjab }\end{array}$ & 15.00 & Bagasse & Steam Turbine \\
\hline 10. & $\begin{array}{l}\text { Alliance Sugar Mills (Pvt.) Limited, Ghotki, } \\
\text { Sindh }\end{array}$ & 30.00 & Bagasse & Steam Turbine \\
\hline 11. & $\begin{array}{l}\text { Ansari Powergen Company (Pvt.) Limited, } \\
\text { Tando Muhammad Khan, Sindh }\end{array}$ & 30.00 & Bagasse & Steam Turbine \\
\hline 12. & $\begin{array}{c}\text { TAY Powergen Company (Pvt.) Limited, } \\
\text { Tando Allayar, Sindh }\end{array}$ & 30.00 & Bagasse & Steam Turbine \\
\hline 13. & $\begin{array}{l}\text { Bandhi Powergen Company (Pvt.) Limited, } \\
\text { Shaheed Benazirabad, Sindh }\end{array}$ & 30.00 & Bagasse & Steam Turbine \\
\hline 14. & $\begin{array}{c}\text { Etohad Power Generation Limited, RYK, } \\
\text { Punjab }\end{array}$ & 74.40 & Bagasse & Steam Turbine \\
\hline 15. & $\begin{array}{l}\text { The Thal Industries Corporation Limited, } \\
\text { Chiniot, Punjab }\end{array}$ & 20.00 & Bagasse & Steam Turbine \\
\hline 16. & $\begin{array}{l}\text { The Thal Industries Corporation Limited, } \\
\text { Layyah, Punjab }\end{array}$ & 41.00 & Bagasse & Steam Turbine \\
\hline 17. & $\begin{array}{c}\text { Almoiz Industries Limited, Mianwali, } \\
\text { Punjab }\end{array}$ & 36.00 & Bagasse & Steam Turbine \\
\hline
\end{tabular}

\subsection{Biomass as Industrial Fuel Source}

Industries running on fossil fuels are one of the main sources of environmental pollution. Biofuels have been recommended as substitutes that can guarantee the security of fuel and reduce levels of greenhouse gas production. All of the regions in the world can obtain these benefits, which would result in a reduction of air pollution, as well as improvements in the quality and freshness of air, rendering the good health of the citizens. A country cannot prosper without a long-lasting power supply to its industries, since the economy depends upon the prosperity of its industries.

Pakistan, even though it is an energy-thirsty nation, still has a lot of potential to run its industries by producing its own biomass-based fuel, because its economy is mostly dependent on agriculture [143]. This fuel would provide an alternative to the huge expenditure of importing fossil fuels from foreign countries [40].

Ethanol and bagasse production from sugar are used as fuels to suffice the heat production requirements in industries. During the last 10 years, the viability of bagasse based-biofuel has been observed and adopted by many countries of the world. For example, in Australia and Brazil, cogeneration is done for heating furnaces and boilers, and it is also sufficient for electricity production [110]. In sugar mills, bagasse serves as energy fuel for firing boilers to heat the juice. In some industries, it is employed to yield medium-density fiberboard, which serves as an alternate for natural wood [144].

\subsection{Biomass in Transportation as Fuel Source}

Reliance of the world on fossil fuels for transportation is currently inevitable. Biofuels and bioethanol are undisputed issues in the World Trade Organization (WTO). A very small number of energy-producing countries that have membership in the WTO have never rightly investigated and 
considered energy concerns, because biofuels constitute a small percentage of the world's energy supply. Biodiesel is still considered an industrial product, but there is an ambiguity regarding bioethanol for its uses, and it is classified as an agricultural product by the WTO. There are two types of biofuels according to different classification methods, i.e., bioethanol and biodiesel, because they are manufactured from an extensive range of materials [145].

Sweden is the world's leader in the use of biomass resources for transportation by modifying biogas to biomethane. Several biogas-based light and heavy vehicles from cars to trains can be found running throughout the country [146]. Dramatic developments have been observed worldwide, e.g., in Europe, 30\% of cars are now diesel-based, which consumes 2/3 times less fuel than petrol-based cars. The US and Brazil have massively increased the production of ethanol and biodiesel [117].

Transportation by road, being the spine of the transport system of Pakistan, has $90 \%$ and $96 \%$ of the passenger traffic and cargo movement of the country, respectively. In the period from 2010-2015, transport fuel consumption increased at $16.5 \%$ of the aggregate growth rate, whereas the increase in the cumulative growth rate for the rest of energy consumption of the country was $4.7 \%$. The energy consumption for the transport sector in 2015 was 32.4\% (13.6 MTOE) of the total country's consumption [147]. Pakistan produces just $18 \%$ of the total fuel using its own resources, while the rest of the $82 \%$ demand is fulfilled through imports [148].

Transportation utilizes about $50 \%$ of the country's oil ingestion, and in 2011-2012, a rise of $5.3 \%$ in this consumption was observed [120]. The transportation system of Pakistan has vehicles with engines that feed on liquefied petroleum gas, natural gas, jet fuel, high-speed diesel, and gasoline. The massive exploitation of natural gas reserves that were discovered in 1952, in the form of Compressed Natural Gas CNG, has outstretched concerns over its sustainable future [142].

Pakistan's situation cannot directly relate to the international biofuel developments, because Pakistan's biofuels have their own particular features that have only recently started to become understood. Vehicle efficiency and performance has been greatly increased by the use of bioethanol in recent years. It also reduces greenhouse gaseous emissions from vehicles [149]. Lower particulate emissions are also less harmful for health. Ongoing backing in research, development, and production is vital to identify the transition trails by which future biofuel systems will start their evolution with an excellent structure of technology and policy changes.

A crucial concern for the biofuel industry is sustainability. If biomass is used as a transport fuel, then it would create a big demand on biomass, which must be produced in a sustainable manner. In the future, biofuel could be a potential market advantage if Pakistan improves its capacity to produce fuel that can be qualified as 'sustainably produced'.

\section{Discussion and Recommendations}

The current scenario regarding the power deficit in Pakistan calls for some immediate steps to overcome this shortfall. The major and foremost problems that have been continuously hindering Pakistan's power sector growth have been listed in Table 22. Their probable and prime reasons, along with their direct consequences, have also been summarized as follows. The problem of the underutilization of the power plants' capacities is caused by their poor maintenance and the deliberate, reluctant behavior of the authorities in full capacity operation. Strict regulatory policies should be devised so that the power plants are compelled to be properly maintained and produce electricity to their full capacity. Pakistan does not have an adequate number of power plants, and the existing ones are less efficient than they should be. Consequently, the undersupply of electricity occurs, and to overcome this problem, investments in efficient-energy projects should be made. The financial problem persists in the energy sector. Hence, wise decisions should be incorporated in those resources that will benefit the energy sector. The new projects face large procedural delays, increasing the overall budget of the project and again causing financial instability. Thus, such delays should be eliminated completely by strict policies that are not affected by any political situation. Technical difficulty handling in power plants should be strengthened to avoid huge blackouts and equipment failure through the 
establishment of institutions that train the work force. High auxiliary power is used, which causes high heat rates and loss of energy. Hence, cogeneration based on renewable energies should also be implemented by exploring new resources. Pakistan suffers from an exploration problem due to a lack of awareness in the society about the potential of renewable energy resources. Also, research and development should be encouraged and done at larger scales to facilitate exploration by government funding. The quality of the power produced by power plants is not up to the mark due to inefficient transmission and distribution networks that have incorporated poor circuit designs and inefficient circuit components. Theft and leakages also play a role in the degradation of the quality of power in the grid, which ultimately leads to low-voltage issues. The low-frequency noise from such a setup also causes health issues. Smart grid systems should be deployed to track down the energy utilization, which will help eliminate power theft. The International Electrotechnical Commission rules-and other rules-must be followed in order to ensure power quality [150,151]. At the end of this study, suggestions have been given that can help overcome those issues.

Although the major energy contribution to date comes from conventional sources (i.e., $65 \%$ from thermal [49]) in Pakistan, the risk involved with these sources is compelling us to shift the energy paradigm toward renewable sources. The first and foremost step on this road is to develop plans and policies so that the utilization of renewable energy can be enhanced. Integrated energy policies should be formulated to find new ventures in the renewable regime and improve the capacity of existing plants, whose chief features should be as follows:

\section{National Security of Energy}

This feature has been elaborated in Table 23, which covers the potential expansion of the use of coal found in the Thar Desert, the exploitation of shale gas and oil, the exploitation of solar, wind, and biomass potential, and the encouragement of hydropower projects based on storage. It shows its importance for Pakistan in becoming self-sufficient regarding energy and minimizing problems regarding payment balancing.

2. Deep Rooted Sustainability of Environment

The share of the power sector in global emissions is $25 \%$, while a $75 \%$ overall share comes from the agriculture, transportation, residential, commercial and industrial sectors. For deep-rooted environmental sustainability, the following measures should be taken:

- All of the sectors of Pakistan should strive to be on par with the international environmental standards.

- To guarantee the complete surveillance of all of the emission sources, the structure of regulations for environmental compliance needs to be revised.

- International Finance Corporation IFC standards for emissions and National Environment Quality Standards NEQS need to be employed in upcoming coal-based projects to control the impact on the environment by using standard technological interferences. Fortunately, it has been predicted that Pakistan will have a far lower level of emissions as compared to many other countries.

\section{Conservation and Efficiency of Energy}

Constant education and awareness are required to transform the outlook of the local populace regarding energy conservation. Energy-efficiency programs should be started, and grants need to be provided to establish a system that has efficient vehicles and efficient lighting. The buildings should implement mandatory disclosure codes/regulations and commercialized benchmark laws. Table 24 lists the areas where efficient energy and conservation measures can be taken. The energy-efficiency practices include efficient vehicles i.e., hybrid/electric vehicles, efficient lighting, and efficient building codes [152]. The efficient vehicles convert $25-40 \%$ of gasoline into energy, while conventional vehicles just convert $17-21 \%$ of the fuel into energy, which increases fuel efficiency. Hybrid vehicles do not emit harmful gases, so these should be paid attention to for implementation at a large scale economically. 
Efficient lighting using Light Emitting Diode LED bulbs give 50-80\% more efficiency than alternate bulbs. Efficient building codes can reduce energy footprints while at the same time benefiting the owners and residents economically.

\section{Competitive Tariff Establishment}

It has been predicted that the upcoming mix of fuel will help lower the fuel cost part of the power tariff. The focus should be to minimize transmission and distribution losses by replacing and/or upgrading the technology that is required for this purpose.

The GoP has planned to develop 5\% of its total energy from the renewable sources by 2030 [9]. For that, the GoP introduced organizations and institutions that pursue the research and development of alternate and renewable energy resources. The Pakistan Council of Renewable Energy Technologies (PCRET), Center for Energy Research and Development (CERAD), and Alternative Energy Development Board (AEDB) are the three main organizations aiming to achieve country's energy mix with a greater share of renewable energy sources. In addition, the major universities of Pakistan are also participating and playing their part in research regarding the renewable energy potential in Pakistan. Table 25 summarizes the research being carried out in the different universities of Pakistan. Regardless of the efforts, there are certain barriers to the implementation of renewable energy systems in abundance that still need to be overcome. They are as follows:

1. Financial barriers

2. Information and technology barriers

3. Institutional barriers

4. Policy barriers

5. Regulatory barriers

While hydropower is contributing almost $31 \%$ of the country's total power production [49], other renewable sources currently have negligible involvement. It has been found that hydropower bears a great capability to help lift the energy supply up to the demand. Pakistan has the capacity for large, small, and mini/micro hydropower projects. Each category has its own advantages and disadvantages, which have been summarized in Table 26. A summary of Table 26 is as follows. Large-scale hydropower projects remain an unfeasible solution in a larger number for Pakistan's current situation, since it is costly in and of itself, even though it supplies many purposes such as irrigation, energy generation, recreation, control of flood, navigation, fishing and supply of water to the population. However, in most cases, its construction costs much more than that because of population displacements and other compensations. Small-scale hydropower projects that are often carried out in hilly areas are harder to scale, and are consequently higher in costs. Above all, their expansion to the national grid is greatly difficult, being susceptible to losses. Hence, the mountain specifications and feasibility analysis should be performed with great care. Mini/micro hydropower projects have an advantage in that they don't require expansion to the grid, and they come under the decentralized power system category. In this case, the costs can be reduced by using efficient components that are often locally available. They are also best suited for poor and rural areas, which leads to the conclusion that small hydropower projects, being the most feasible, should be started at various locations all over Pakistan with suitable terrain. The GoP has permitted a $17 \%$ internal rate of return to inspire the installment of hydel-based projects.

Pakistan is blessed with various landforms such as plains, plateaus, mountains, and coastal areas. Coastal areas act as a hub for wind energy. According to international standards, wind sources in Jamshoro are befitting for power generation due to their high speed [1]. Thus, more wind turbines should be installed there in order to achieve higher wind generation potential, because Pakistan has $132 \mathrm{GW}$ of wind power potential, but is only utilizing only $1 \%$ of it. Due to firming up the infrastructure of institutions, three wind farms have been established that are interconnected with the national grid. They add over $150 \mathrm{MW}$ to the national grid, and further wind projects are near the 
completion stages. For a quick implementation of wind-based projects, the following recommendations should be considered:

1. Maintenance and improvement in the strength of the infrastructure of institutions, as per the increase in the demand of energy, should be ensured.

2. There should be a fast processing of project proposals, eliminating procedural delays that ultimately cause cost overruns.

3. The usage of latest technologies, and by reducing tariffs, wind power generation can be more rewarding. However, the key challenges of frequency mismatch and lack of grid connectivity must be addressed on a higher priority.

4. International and private investors should be made aware of and educated regarding the striking renewable energy policy put forward in 2011, which holds great incentives for wind power project investors.

5. The wind power plants need to operate on a commercial level that can result in a wind power contribution of $2.6 \mathrm{GW}$, and thus, the goal of the GoP of attaining a $5 \%$ share of renewable energy can be met by 2030 .

At present, power generation from solar energy is continuously growing in Pakistan. Although Pakistan has an estimated potential of 2.9 Million MW, only 1\% is currently being utilized. Government of Pakistan can help encourage solar-based projects. Recommendations are as follows [9].

1. Provision of subsidies on PV cells should be ensured.

2. Solar cells can be made more feasible by locally producing them, which will eventually reduce the cost of electricity.

3. Awareness should be spread among local communities, and proper technical information should be available to guide them.

4. Peak demand of load can be managed by shifting toward PV-based solar cells. Street lights and parks can be illuminated by them to shed the load off the grid.

5. Since a large area is needed to install PV cells for solar farms, these can be aptly installed in remote areas of Baluchistan, Sindh, and Punjab to fulfil the energy requirements of the local communities. The mountainous regions of the country can be exploited as well, since they get a lot of solar radiation for long hours on a daily basis.

Geothermal resources are in abundance in Pakistan, but due to a lack of proper policies and the required database, they have never been capitalized on a large scale. Consistent and thorough research and development (R\&D) is required to clear pathways for utilizing geothermal potential. It has been observed that since Pakistan is situated on tectonic plate junctions, they can offer high, medium, and low temperature reservoirs for electricity generation. Pakistan has no geothermal power plant yet, so this domain is a blue ocean for Pakistan that thoroughly needs to be brought to the fore.

Biomass-based energy is resourceful, sustainable, cost-effective, socially acceptable, and environment friendly alternative for power production [22]. Being a new field, it is in the early stages of development, and more research is required to get the most out of it. Three major sources for biomass in Pakistan are bagasse, poultry waste, and municipal waste. It has been proven that biogas-based plants have less of an environmental impact than PV and wind technologies. Table 27 summarizes the analysis of biomass potential in this study. The summary of Table 27 is given as follows. Bagasse can produce over $3000 \mathrm{MW}$ of power by cogeneration techniques. The use of biomass sources for cogeneration is encouraged because of biomass degradation to environmentally harmful methane gas. Poultry waste, if processed and utilized for producing biogas, can generate $300 \mathrm{MWh}$ of energy per day. Similarly, municipal solid waste is also left over in large quantities of 32.3 MT per year. The associated processing technologies and awareness needs to be raised in all three resources. This potential can be utilized for power production and as a fuel source in industries and transport vehicles, as summarized in Table 28. The summary of Table 28 is given as follows. Up until 2014, 
Pakistan did not have any biomass-based power generation capability. Afterwards, the potential for biomass-based power plants was explored, and during 2015-2016, 547 GWh of energy was harvested from such schemes. The capabilities that biomass holds in this regard have started to be acknowledged in Pakistan. Consequently, more such projects are being launched for power generation. Biomass-based fuel for transportation and industrial fuel has been known to be more efficient and beneficial for the vehicle performance and the environment as well. Pakistan needs to follow other countries such as Sweden that consume biomass-based fuel in their vehicles, so that Pakistan's expense on importing fuel gets lowered. Although some small biomass-based projects are running in the country, they are still not capable of producing any big impact. One basic hurdle in adopting biomass-based energy sources is a lack of financial and technological support [132], which can be easily overcome with the help of public-private partnership.

This study would have been further enhanced if the data related to bagasse, poultry waste, and municipal solid waste could be obtained from the major cities of Pakistan by direct survey from related organizations by arranging a field trip. Still, the data has been obtained from recent reliable sources, which suffice to fulfil the objectives of this study.

This study enables examining the state of power and energy harnessed from all of the available and potential resources in Pakistan. Keeping in view all of the aspects mentioned in this section, it can be deduced because of this study that biomass is the most economical and readily available resource that can be used to harness energy to generate power and as transportation and industrial fuel. Other renewable resources such as solar, wind, and geothermal resources are too expensive to set up at a large scale for Pakistan's current economic situation, even though they have a lot of potential. They also require more complex technologies and large manpower for their setup, which in the case of biomass, is relatively less of a problem. Hence, this comprehensive study may enable the government and investors to make wise decisions about the most suitable resource that, if implemented in upcoming and future projects, will help reduce the supply and demand gap in a minimal time span. Hence, they may set priorities on the utilization of these resources based on this study for their future investments. In this study, biomass has been found to be that resource which is environmentally, sustainably, and economically the most feasible in solving the power and energy issues, and should be set up as the highest priority for its utilization in all possible aspects. 
Table 22. Major problems of the power sector of Pakistan: reasons, consequences, and solutions.

\begin{tabular}{|c|c|c|c|c|c|}
\hline Sr. No. & $\begin{array}{c}\text { Major Problems of } \\
\text { Power Sector of Pakistan }\end{array}$ & Reasons & Consequences & Suggestions for Solutions & References \\
\hline 1 & $\begin{array}{l}\text { Capacities of power } \\
\text { plants are not fully } \\
\text { utilized }\end{array}$ & $\begin{array}{l}\text { 1. Poor maintenance of } \\
\text { power plants } \\
\text { 2. Deliberate reluctance in fully } \\
\text { fledged operation of } \\
\text { power plants }\end{array}$ & $\begin{array}{l}\text { 1. Utilization factor per annum is lowered } \\
\text { 2. Load shedding } \\
\text { 3. Deficient performance of power plants } \\
\text { 4. Availability of units is constantly declining } \\
\text { 5. Higher heat rates are observed than } \\
\text { National Electric Power Regulatory } \\
\text { Authority (NEPRA)'s approved heat rate }\end{array}$ & $\begin{array}{l}\text { 1. Constant and strict performance monitoring } \\
\text { by higher authorities. } \\
\text { 2. Call for periodic reports from power plant } \\
\text { authorities frequently. } \\
\text { 3. Strict policies should be developed to force } \\
\text { the power plant authorities to ensure full } \\
\text { utilization of capacity. }\end{array}$ & {$[1,21,51]$} \\
\hline 2 & $\begin{array}{l}\text { Inadequate power supply } \\
\text { relative to demand }\end{array}$ & $\begin{array}{ll}\text { 1. } & \begin{array}{l}\text { Small number of } \\
\text { power plants }\end{array} \\
\text { 2. } & \text { Inefficiency of power plants }\end{array}$ & $\begin{array}{l}\text { 1. Many factories and industries have been } \\
\text { shut down } \\
\text { 2. Pakistan's economic growth has been } \\
\text { negatively affected }\end{array}$ & $\begin{array}{l}\text { 1. Measures should be taken to imply } \\
\text { international standards to improve the } \\
\text { performance of the grid to minimize } \\
\text { energy losses. }\end{array}$ & {$[9,18]$} \\
\hline 3 & Financing issues & $\begin{array}{l}\text { 1. Control of the power sector } \\
\text { is centralized } \\
\text { 2. Wrong funding priorities } \\
\text { 3. Circular debt }\end{array}$ & $\begin{array}{l}\text { 1. Lack of investments in new and } \\
\text { novel projects } \\
\text { 2. Aging and degradation of existing plants } \\
\text { 3. Unworthy investments leading to } \\
\text { expensive failure } \\
\text { 4. Higher electricity costs }\end{array}$ & $\begin{array}{l}\text { 1. Proper rules and regulations should be } \\
\text { incorporated for project financing schemes. } \\
\text { 2. Feasibility surveys should be carried out } \\
\text { before project execution. } \\
\text { 3. Risk management should be employed } \\
\text { according to risk register. } \\
\text { 4. Encouragement of private power sector } \\
\text { is necessary. }\end{array}$ & {$[4,21,39,51,54$} \\
\hline 4 & Procedural delays & $\begin{array}{ll}\text { 1. } & \text { Political situations } \\
\text { 2. } & \begin{array}{l}\text { Poor project } \\
\text { management skills }\end{array} \\
\text { 3. } & \begin{array}{l}\text { Deliberate suppression of } \\
\text { approvals by authorities for } \\
\text { organizational benefits }\end{array}\end{array}$ & $\begin{array}{l}\text { 1. Delay in the start of operation of } \\
\text { power plant } \\
\text { 2. Lowering of annual factor of utilization }\end{array}$ & $\begin{array}{l}\text { 1. Policies should be such that no political } \\
\text { situation can affect the welfare projects. } \\
\text { 2. Project should be properly managed by } \\
\text { experienced project managers who strictly } \\
\text { follow the work breakdown structure of } \\
\text { the project. }\end{array}$ & {$[12,21,54]$} \\
\hline 5 & $\begin{array}{l}\text { Lack of expertise in } \\
\text { catering of technical } \\
\text { difficulties }\end{array}$ & $\begin{array}{l}\text { 1. Lack of technical staff } \\
\text { with expertise } \\
\text { 2. Lack of availability of jobs in } \\
\text { such areas }\end{array}$ & $\begin{array}{l}\text { 1. Switchyard equipment failure } \\
\text { 2. Large system blackouts }\end{array}$ & $\begin{array}{l}\text { 1. Institutions should be developed for special } \\
\text { training to cater for the technical faults in } \\
\text { power systems. } \\
\text { 2. Job vacancies for capable and intelligent } \\
\text { people should be increased in the } \\
\text { power sector. }\end{array}$ & {$[18,21,48]$} \\
\hline
\end{tabular}


Table 22. Cont.

\begin{tabular}{|c|c|c|c|c|c|}
\hline Sr. No. & $\begin{array}{c}\text { Major Problems of } \\
\text { Power Sector of Pakistan }\end{array}$ & Reasons & Consequences & Suggestions for Solutions & References \\
\hline 6 & $\begin{array}{l}\text { High consumption of } \\
\text { Auxiliary power }\end{array}$ & $\begin{array}{l}\text { 1. Poor efficiencies of power } \\
\text { generation equipment } \\
\text { 2. Actual power production } \\
\text { capacity of the plant is lower } \\
\text { than the requirement of } \\
\text { auxiliary power. }\end{array}$ & $\begin{array}{l}\text { 1. Higher heat rates } \\
\text { 2. Loss of energy e.g., in 2016, national } \\
\text { exchequer faced financial deterioration due } \\
\text { to overutilization of auxiliary power by TPS } \\
\text { Guddu, leading to } 121.089 \text { GWh loss } \\
\text { of energy. }\end{array}$ & $\begin{array}{l}\text { 1. Cogeneration schemes, such as } \\
\text { bagasse-based cogeneration, should be } \\
\text { employed to power the auxiliary } \\
\text { generation equipment. }\end{array}$ & {$[18,21,30]$} \\
\hline 7 & $\begin{array}{l}\text { Primitive methods } \\
\text { utilized for electricity } \\
\text { generation }\end{array}$ & 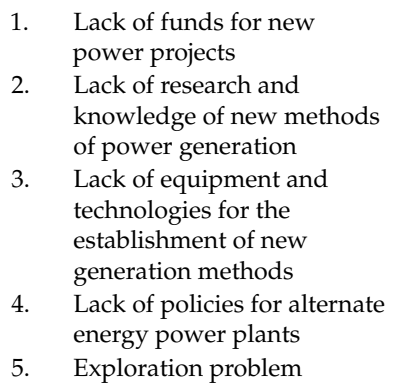 & $\begin{array}{l}\text { 1. Primary energy resources such as oil, coal, } \\
\text { and gas are being depleted } \\
\text { 2. Greenhouse emission levels are increasing } \\
\text { 3. Low energy efficiency being obtained from } \\
\text { existing plants e.g., power plant in Uch } \\
\text { produces only a few MW, even though it is } \\
\text { capable of generating } 800 \mathrm{MW} \text {. }\end{array}$ & $\begin{array}{l}\text { 1. Research and development of alternate and } \\
\text { renewable energy resources should be } \\
\text { pursued along with their implementation in } \\
\text { new power plants. } \\
\text { 2. Policies should be updated according to the } \\
\text { requirements of alternate and renewable } \\
\text { energy resources such as solar, wind, } \\
\text { and biomass. }\end{array}$ & {$[1,9,13,21]$} \\
\hline 8 & $\begin{array}{l}\text { Lower power Quality and } \\
\text { low frequency noise }\end{array}$ & $\begin{array}{ll}\text { 1. Instability of transmission } \\
\text { and distribution grid } \\
\text { 2. Power theft } \\
\text { 3. Leakages } \\
\text { 4. Technical faults in } \\
\text { manufacturing conductors } \\
\text { and their weakening } \\
\text { 5. Poor design of circuitry }\end{array}$ & $\begin{array}{l}\text { 1. Low-voltage issue arises } \\
\text { 2. Transmission circuit's efficiency is lowered } \\
\text { 3. Affects human health and causes distress }\end{array}$ & $\begin{array}{l}\text { 1. Measures should be taken to improve the } \\
\text { transmission and distribution circuits and } \\
\text { equipment such as transformers, } \\
\text { transmission lines, spacers, insulators, } \\
\text { and dampers. } \\
\text { 2. Employment of Smart Grid system that will } \\
\text { also help monitor the overall power system } \\
\text { to avoid theft issues as well along with } \\
\text { other benefits. } \\
\text { International Electrotechnical Commission } \\
\text { rules along with other standards should be } \\
\text { followed to enhance the quality of power. }\end{array}$ & {$[1,4,18,21,39]$} \\
\hline
\end{tabular}


Table 23. Integrated energy policy regarding the national security of energy.

\begin{tabular}{|c|c|c|c|c|}
\hline Sr. No. & & Potential & & Discussion/Recommendations \\
\hline 1 & $\begin{array}{c}\text { Expansion of use of coal found in Thar } \\
\text { Desert }\end{array}$ & $\begin{array}{l}\text { - Seventh largest reserves of coal are } \\
\text { situated here } \\
\text { - The grade of coal is lignite, and its quantity } \\
\text { is } 175 \text { billion tons } \\
\text { This quantity has the potential to serve for } \\
\text { more than } 100 \text { years with a power generation } \\
\text { capacity of } 100,000-200,000 \mathrm{MW}\end{array}$ & $\begin{array}{l}\text { i. } \\
\text { ii. }\end{array}$ & $\begin{array}{l}\text { To intrigue the private sector to invest, } \\
\text { incentives in tariffs and mining should } \\
\text { be given } \\
\text { Water should be made available to convert } \\
\text { to steam for power generation }\end{array}$ \\
\hline 2 & Exploitation of shale gas and oil & $\begin{array}{l}\text { - Shale gas: } 105 \text { trillion cubic feet } \\
\text { - } \quad \text { Efficie Oil reserves: } 9.1 \text { billion barrels } \\
60-62 \% \text { at } 6-7 \text { cents } / \mathrm{kWh} \text { cycle RLNG plants is } \\
\text { - Assurance of native gas obtainability to } \\
\text { further reduce tariff via search of tight and } \\
\text { shale gas should be done. }\end{array}$ & i. & $\begin{array}{l}\text { Policy should give incentives for quick } \\
\text { potential growth of tight and shale gas/oil } \\
\text { New areas should be explored }\end{array}$ \\
\hline 3 & $\begin{array}{c}\text { Exploitation of solar, wind, and biomass } \\
\text { potential }\end{array}$ & $\begin{array}{l}\text { - } \quad \text { Wind: } 132 \mathrm{GW} \\
\text { - } \quad \text { Solar: 2.9 Million MW } \\
\quad \text { Biomass: 4000-6000 MW }\end{array}$ & $\begin{array}{l}\text { i. } \\
\text { ii. } \\
\text { iii. } \\
\text { iv. }\end{array}$ & $\begin{array}{l}\text { Revision of import policy for tariff of solar } \\
\text { equipment to promote solar applications } \\
\text { Establish local industry for manufacturing } \\
\text { of solar equipment } \\
\text { Net metering should be employed by } \\
\text { utility authorities } \\
\text { Encouragement of off-grid applications to } \\
\text { supply power to the deprived } \\
27 \% \text { population }\end{array}$ \\
\hline 4 & $\begin{array}{l}\text { Encouragement of hydropower projects } \\
\text { based on storage }\end{array}$ & $\begin{array}{l}\text { - Such projects have a capability of generating } \\
\text { 60,000 MW. At present, } 7116 \mathrm{MW} \text { are } \\
\text { being generated } \\
\text { - } 4000 \mathrm{MW} \text { of hydel-based projects are at } \\
\text { various steps of implementation } \\
\text { - Water and Power Development Authority } \\
\text { (WAPDA) is also dealing with projects that } \\
\text { are at the feasibility stage with 25,000 MW }\end{array}$ & $\begin{array}{l}\text { i. } \\
\text { ii. } \\
\text { iii. }\end{array}$ & $\begin{array}{l}\text { Feasibility analysis must be done prior to } \\
\text { the beginning of the project } \\
\text { Allocation of budget should be done } \\
\text { Cogeneration schemes should be } \\
\text { emphasized to strengthen } \\
\text { current infrastructure }\end{array}$ \\
\hline
\end{tabular}


Table 24. Integrated energy policy regarding the conservation and efficiency of energy.

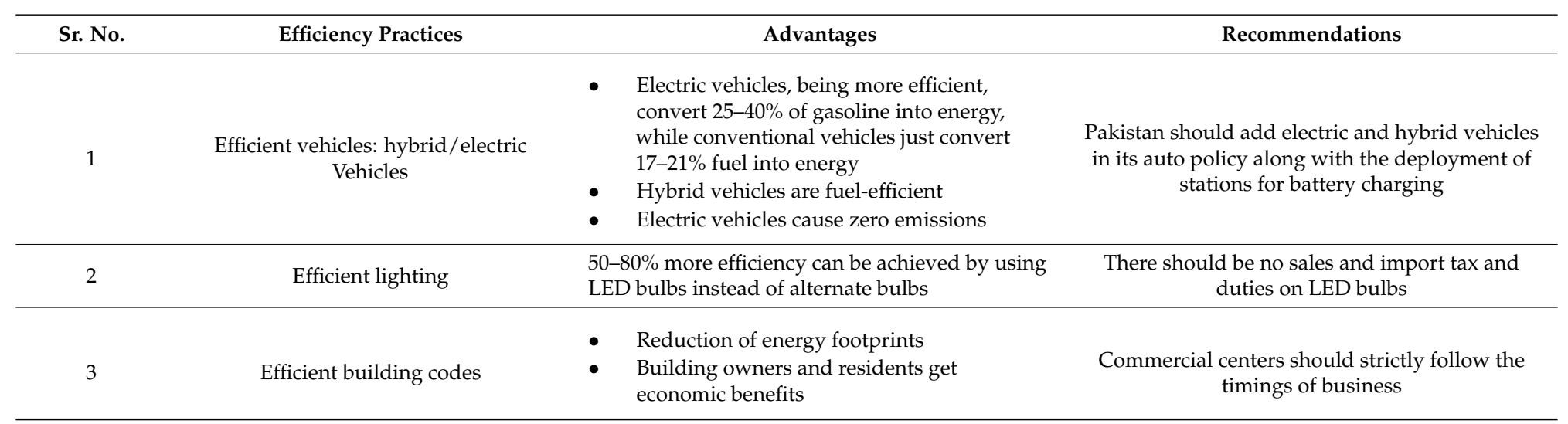

Table 25. Ongoing research on renewable energy resources and technologies in universities of Pakistan.

\begin{tabular}{|c|c|c|}
\hline Sr. No. & University & Research Directions \\
\hline 1 & Ghulam Ishaq Khan Institute GIK, Toppi, Khyber Pakhtunkhwa KPK & Solar cells \\
\hline 2 & Government College University, Lahore & Biofuel production from biomass \\
\hline 3 & Mehran University of Engineering and Technology, Jamshoro & Bioenergy \\
\hline 4 & National University of Science and Technology (NUST), Islamabad & $\begin{array}{ll}\text { - } & \text { Biomass } \\
\text { - } & \text { Electric vehicles } \\
\text { - } & \text { Wind turbines } \\
\text { - } & \text { Solar thermal energy }\end{array}$ \\
\hline 5 & $\begin{array}{c}\text { Nadirshaw Eduljee Dinshaw NED University of Engineering \& } \\
\text { Technology Karachi. }\end{array}$ & $\begin{array}{l}\text { - Solar collectors } \\
\text { - } \quad \text { Wind turbines }\end{array}$ \\
\hline 6 & Quaid e Awam University of Science and Technology, Nawabshah & $\begin{array}{l}\text { - Utilization of solar energy } \\
\text { - Solar tracker }\end{array}$ \\
\hline 7 & Quaid e Azam university Islamabad & Biofuel technology \\
\hline
\end{tabular}


Table 26. Analysis of hydropower potential in Pakistan's context.

\begin{tabular}{|c|c|c|c|c|c|c|}
\hline Sr. No. & $\begin{array}{l}\text { Hydropower Project } \\
\text { Category }\end{array}$ & $\begin{array}{l}\text { Factors Deciding the } \\
\text { Category }\end{array}$ & Advantages & & Disadvantages & Discussion and Recommendations \\
\hline \multirow[t]{2}{*}{1} & \multirow[t]{2}{*}{ Large } & \multirow[t]{2}{*}{$\begin{array}{l}\text { Requirement of large dam } \\
\text { size }\end{array}$} & $\begin{array}{l}\text { Serves numerous purposes. } \\
\text { For example }\end{array}$ & \multirow[b]{2}{*}{$\begin{array}{l}\text { ii. } \\
\text { iii. } \\
\text { iv. } \\
\text { v. } \\
\text { vi. }\end{array}$} & \multirow[b]{2}{*}{$\begin{array}{l}\text { The size of the dam causes } \\
\text { the forced relocations of } \\
\text { local settlements. Such } \\
\text { objections have been raised } \\
\text { on the Kalabagh } \\
\text { dam project } \\
\text { Costly } \\
\text { Greater construction time } \\
\text { Buildup of sediments } \\
\text { Barrier to fish migration } \\
\text { Decomposition of biomass } \\
\text { releases } \mathrm{CH}_{4} \text { and } \mathrm{CO}_{2} \text {. } \\
\text { Technical, social, and } \\
\text { political issues are related } \\
\text { to them }\end{array}$} & $\begin{array}{l}\text { Considering sustainable development, this scheme is not } \\
\text { reliable because of the following reasons: }\end{array}$ \\
\hline & & & $\begin{array}{ll}\text { i. } & \text { Irrigation } \\
\text { ii. } & \text { Energy generation } \\
\text { iii. } & \begin{array}{l}\text { Supply of water } \\
\text { to population }\end{array} \\
\text { iv. } & \text { Control of flood } \\
\text { v. } & \text { Navigation } \\
\text { vi. } & \text { Fishing } \\
\text { vii. } & \text { Recreation }\end{array}$ & & & $\begin{array}{l}\text { i. To compensate for population displacement and the } \\
\text { degradation of the environment, there has been a } \\
\text { demand that their costs have to be adjusted with } \\
\text { upfront costs. Financing is already a problem in } \\
\text { Pakistan, which renders this scheme as an } \\
\text { unreliable option. } \\
\text { ii. } \\
\text { If, somehow, arrangements of funds are made by the } \\
\text { government, the expenses of resettlements are huge, } \\
\text { e.g., \$33.2 billion will be spent on the resettlement } \\
\text { associated with the Kalabagh dam through the } \\
\text { construction of } 20 \text { model and } 27 \text { extended villages. }\end{array}$ \\
\hline 2 & Small & $\begin{array}{l}\text { Requirement in hilly areas } \\
\text { with an abundance of } \\
\text { controllable and natural } \\
\text { waterfalls }\end{array}$ & $\begin{array}{l}\text { Cost of equipment, civil } \\
\text { work, and overall } \\
\text { establishment depends } \\
\text { upon the location only } \\
\text { Power profile permits } \\
\text { immediate response to } \\
\text { demand fluctuations; } \\
\text { addressing both base and } \\
\text { peak demands of load } \\
\text { Lower impact on ecosystem } \\
\text { No reservoir required }\end{array}$ & iii. & $\begin{array}{l}\text { More expensive than } \\
\text { large-scale } \\
\text { hydropower projects. } \\
\text { Harder in terms of scaling } \\
\text { than large-scale } \\
\text { hydropower projects. } \\
\text { It is difficult to expand the } \\
\text { grid in hilly areas, which } \\
\text { are prone to losses }\end{array}$ & $\begin{array}{l}\text { Mountain specifications and feasibility analysis should } \\
\text { be done. } \\
\text { Since this category is less risky, and has profound } \\
\text { advantages, it can be helpful in keeping pace with the } \\
\text { increasing energy demand. }\end{array}$ \\
\hline 3 & Mini/Micro & $\begin{array}{l}\text { They are site-specific } \\
\text { especially with no grid } \\
\text { extension }\end{array}$ & $\begin{array}{l}\text { No storage required } \\
\text { Can be made less expensive } \\
\text { Decentralized } \\
\text { power system }\end{array}$ & $\begin{array}{l}\text { i. } \\
\text { ii. }\end{array}$ & $\begin{array}{l}\text { Lower load factor } \\
\text { Slow demand buildup }\end{array}$ & $\begin{array}{l}\text { Lower costs can be achieved by selecting components } \\
\text { that boost efficiency. } \\
\text { Since this scheme is employed in mostly poor and rural } \\
\text { communities, these projects act as a source of income } \\
\text { for them, since it can be locally made. This type is also } \\
\text { beneficial for Pakistan, after the small } \\
\text { hydropower scheme. }\end{array}$ \\
\hline
\end{tabular}


Table 27. Analysis of major biomass resources.

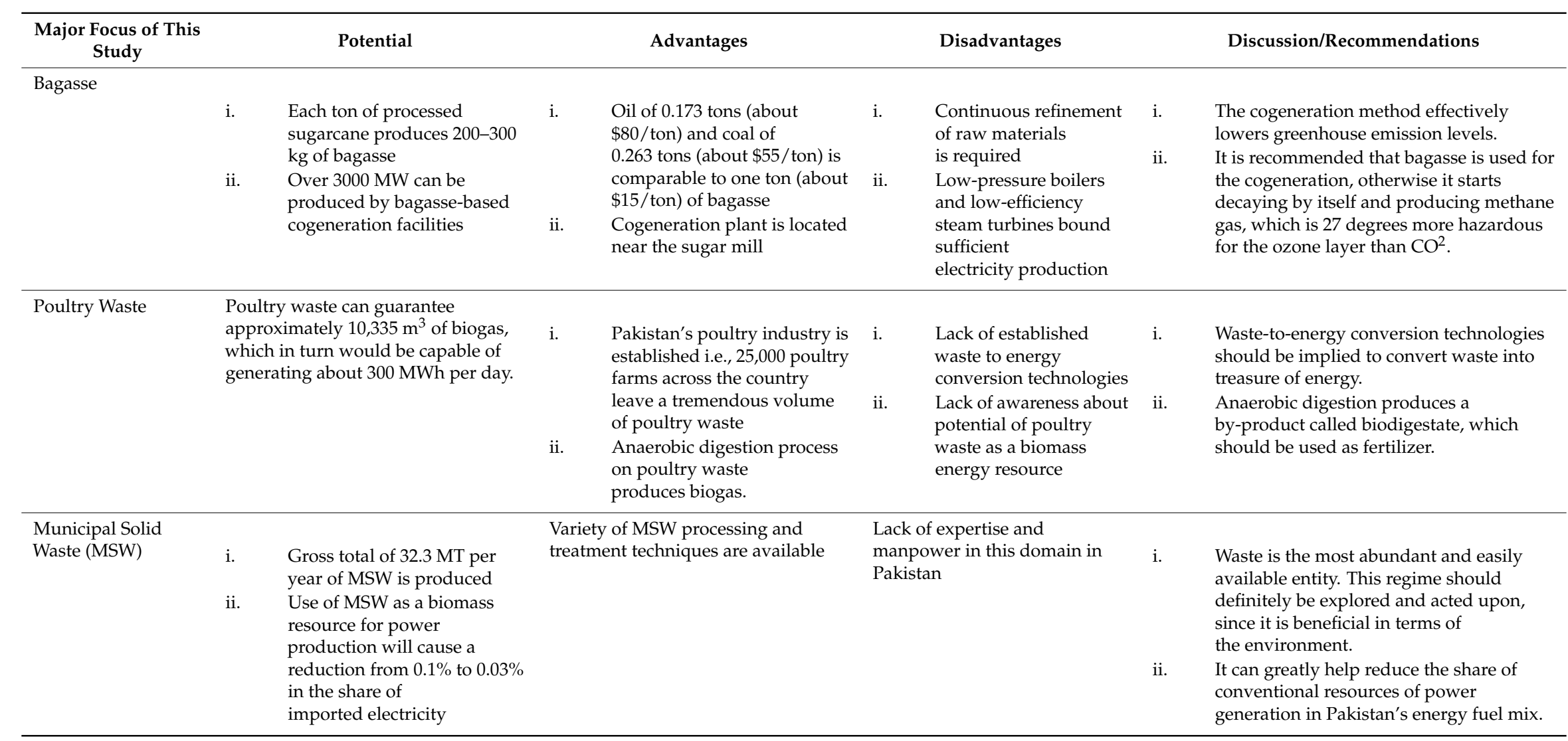


Table 28. Biomass utilization in Pakistan for power production, transportation, and industrial fuel.

\begin{tabular}{|c|c|c|c|c|c|}
\hline Sr. No. & Biomass Application & Potential & & Key Observations & Discussion \\
\hline 1 & Power Production & $\begin{array}{l}\text { In the National Transmission } \\
\text { and Dispatch Company } \\
\text { (NTDC)'s system, an increase in } \\
\text { power generation of about } \\
63 \mathrm{MW} \text { for a total of about } \\
146 \mathrm{MW} \text { from bagasse-based } \\
\text { power plants has been observed } \\
\text { during 2015-2016 having an } \\
\text { energy of } 547 \text { GWh. }\end{array}$ & $\begin{array}{l}\text { i. } \\
\text { ii. } \\
\text { iii. } \\
\text { iv. } \\
\text { v. }\end{array}$ & $\begin{array}{l}\text { Pakistan lacked any } \\
\text { biomass / bagasse-based power plants } \\
\text { until } 2014 \\
\text { The projects started in } 2015 \text { are majorly } \\
\text { based on bagasse fuel } \\
\text { Their technologies make use of } \\
\text { steam turbines } \\
35 \text { captive power producers (CPPs) are using } \\
\text { biomass/bagasse for power production } \\
\text { Shakarganj Energy (Pvt.) Limited is the } \\
\text { only Isolated Generation Company (IGC) for } \\
\text { energy production using biomass }\end{array}$ & $\begin{array}{l}\text { The year } 2015 \text { has been beneficial in terms of the } \\
\text { start of biomass-based power production. Many } \\
\text { projects have been put forward for } \\
\text { implementation, since companies have found it to } \\
\text { be a convenient way to generate electricity. }\end{array}$ \\
\hline 2 & Transportation & $\begin{array}{ll}\text { i. } & \begin{array}{l}\text { Vehicle efficiency and } \\
\text { performance can be } \\
\text { greatly increased using } \\
\text { biomass-based fuels } \\
\text { such as bioethanol } \\
\text { and biodiesel }\end{array} \\
\text { ii. } \quad \text { Environmentally-friendly }\end{array}$ & $\begin{array}{l}\text { ii. } \\
\text { fuel }\end{array}$ & $\begin{array}{l}\text { The transportation system of Pakistan has } \\
\text { vehicles with engines that feed on } \\
\text { liquefied petroleum gas, natural gas, jet } \\
\text { fuel, high-speed diesel, and gasoline. } \\
\text { Countries such as Sweden use biomass } \\
\text { resources for transportation by modifying } \\
\text { biogas to biomethane }\end{array}$ & $\begin{array}{l}\text { Pakistan imports a huge amount of fossil fuels to } \\
\text { fulfill its transportation needs. Pakistan also needs } \\
\text { to follow the concept of using biomass-based fuels } \\
\text { to feed the vehicular engines. }\end{array}$ \\
\hline 3 & Industrial Fuel & $\begin{array}{l}\text { Biofuels have been } \\
\text { recommended as substitutes } \\
\text { guaranteeing the security of fuel } \\
\text { and reduced levels of } \\
\text { greenhouse gas production. }\end{array}$ & Paki & $\begin{array}{l}\text { an's industries are still using fossil fuels that } \\
\text { oduce harmful gases that are bad for the } \\
\text { environment }\end{array}$ & $\begin{array}{l}\text { Pakistan has a lot of potential to run the } \\
\text { industries by producing its own } \\
\text { biomass-based fuel, instead of importing } \\
\text { fossil fuels from foreign countries. } \\
\text { Pakistan can start from using cogeneration } \\
\text { for heating furnaces and boilers for juice } \\
\text { heating and yield medium-density } \\
\text { fiberboard, which is an alternate for } \\
\text { natural wood. } \\
\text { This will help clean the environment, too. }\end{array}$ \\
\hline
\end{tabular}




\section{Conclusions}

Pakistan is in dire need of the diversification of its energy mix to lessen its reliance upon fossil fuels and its consequences on the environment. This review concludes that the government of Pakistan should prioritize biomass energy based-projects among other renewable energy resources, since it would prove to be the most economical and environment-friendly resource. This would lead to a quick bridging of the gap between the demand and supply of energy. In the future, this study can be further enhanced by obtaining data from organizations and institutions that will help the government model biomass-based projects.

Author Contributions: All the authors contributed in completing the Paper. The main idea of the paper was presented by W.U.K.T. while Z.A., N.Y., L.S., and I.F. helped in accumulating the research data in this review paper. M.A., M.S., B.H., and L.W.C. prepared the format of the paper. S.M., S.A.M., and M.D. are the head of research team.

Funding: The authors would like to acknowledge the financial support received from the University of Malaya, Malaysia, through Frontier Research Grant No. FG007-17AFR and Innovative Technology Grant No. RP043B-17AET.

Conflicts of Interest: The authors declare no conflict of interest.

\section{Abbreviations}

$\begin{array}{ll}\text { AEDB } & \text { Alternative Energy Development Board } \\ \text { BRB } & \text { Bambawali Ravi Bedian } \\ \text { COD } & \text { Commercial operation dates } \\ \text { CPP } & \text { Captive power producers } \\ \text { CNG } & \text { Compressed natural gas } \\ \text { CERAD } & \text { Center for Energy Research and Development } \\ \text { EJ } & \text { Exa joule } \\ \text { FY } & \text { Financial year } \\ \text { GENCOs } & \text { Generation Companies } \\ \text { GHG } & \text { Greenhouse gas } \\ \text { GWEC } & \text { Global Wind Energy Council } \\ \text { GW } & \text { Gigawatts } \\ \text { GWh } & \text { Gigawatt-hour } \\ \text { GDP } & \text { Gross domestic product } \\ \text { GoP } & \text { Government of Pakistan } \\ \text { HSD } & \text { High-speed diesel } \\ \text { HDR } & \text { Hard Dry Rock } \\ \text { HVAC } & \text { Heating, ventilation and air conditioning } \\ \text { IPPs } & \text { Independent power producers } \\ \text { IGC } & \text { Isolated Generation Company } \\ \text { IFC } & \text { International Finance Corporation } \\ \text { IEA } & \text { International Energy Agency } \\ \text { K-EL } & \text { K-Electric's } \\ \text { KPIs } & \text { Key performance indicators } \\ \text { KANUPP } & \text { Karachi Nuclear Power Plant } \\ \text { KTOE } & \text { Kilotonne of oil equivalent } \\ \text { MW } & \text { Megawatts } \\ \text { MT } & \text { Megatons } \\ \text { MCM } & \text { Million cubic meters } \\ \text { MSW } & \text { Municipal solid waste } \\ \text { NREL } & \text { National Renewable Energy Laboratory } \\ \text { NEPRA } & \text { National Electric Power Regulatory Authority } \\ \text { NEQS } & \text { National Environment Quality Standards } \\ \end{array}$




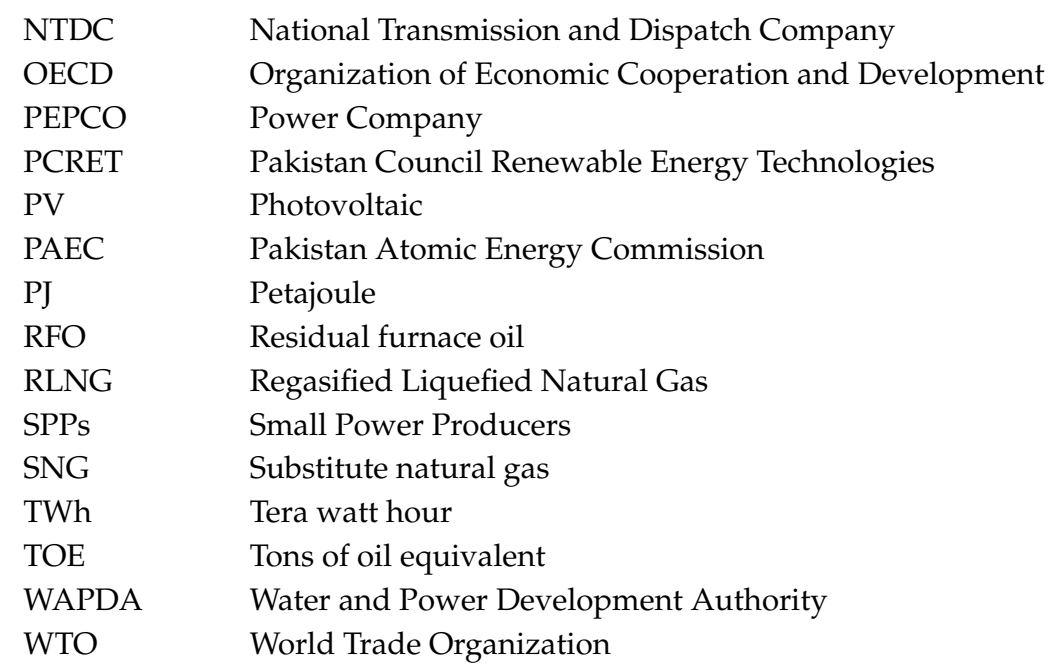

\section{References}

1. Baloch, M.H.; Kaloi, G.S.; Memon, Z.A. Current scenario of the wind energy in Pakistan challenges and future perspectives: A case study. Energy Rep. 2012, 2, 201-210. [CrossRef]

2. Bianco, V.; Manca, O.; Nardini, S. Electricity consumption forecasting in Italy using linear regression models. Energy 2009, 34, 1413-1421. [CrossRef]

3. Birol, F. World Energy Prospects and Challenges. Asia-Pac. Rev. 2007, 14, 1-12. [CrossRef]

4. International Energy Outlook 2010. Available online: http://large.stanford.edu/courses/2010/ph240/ riley2/docs/EIA-0484-2010.pdf (accessed on 18 August 2018).

5. Kaygusuz, K. Wind energy status in renewable electrical energy production in Turkey. Renew. Sustain. Energy Rev. 2010, 14, 2104-2112. [CrossRef]

6. Key World Energy Statistics. Available online: http://alofatuvalu.tv/FR/12_liens/12_articles_rapports / IEA_rpt_2012_us.pdf (accessed on 18 August 2018).

7. Data Collection Survey on Renewable Energy Development in Pakistan Final Report. Available online: open_jicareport.jica.go.jp/pdf/12086740_01.pdf (accessed on 18 August 2018).

8. Krewitt, W.; Simon, S.; Graus, W.; Teske, S.; Zervos, A.; Schäfer, O. The 2 C scenario-A sustainable world energy perspective. Energy Policy 2007, 35, 4969-4980. [CrossRef]

9. Rafique, M.M.; Rehman, S. National energy scenario of Pakistan-Current status, future alternatives, and institutional infrastructure: An overview. Renew. Sustain. Energy Rev. 2017, 69, 156-167. [CrossRef]

10. Stanek, W.; Czarnowska, L.; Gazda, W.; Simla, T. Thermo-ecological cost of electricity from renewable energy sources. Renew. Energy 2018, 115, 87-96. [CrossRef]

11. Breeze, P. Chapter 6-Renewable Energy and the Environment. In Electricity Generation and the Environment. Available online: http:/ / www.sciencedirect.com/science/article/pii/B9780081010440000068 (accessed on 18 August 2018).

12. Burke, M.J.; Stephens, J.C. Political power and renewable energy futures: A critical review. Energy Res. Soc. Sci. 2018, 35, 78-93. [CrossRef]

13. Mitchell, J.V.; Mitchell, B. Structural crisis in the oil and gas industry. Energy Policy 2014, 64, 36-42. [CrossRef]

14. Sher, H.A.; Murtaza, A.F.; Addoweesh, K.E.; Chiaberge, M. Pakistan's progress in solar PV based energy generation. Renew. Sustain. Energy Rev. 2015, 47, 213-217. [CrossRef]

15. Kamran, M. Current status and future success of renewable energy in Pakistan. Renew. Sustain. Energy Rev. 2018, 82, 609-617. [CrossRef]

16. Rauf, O.; Wang, S.; Yuan, P.; Tan, J. An overview of energy status and development in Pakistan. Renew. Sustain. Energy Rev. 2015, 48, 892-931. [CrossRef]

17. Rodríguez-Monroy, C.; Mármol-Acitores, G.; Nilsson-Cifuentes, G. Electricity generation in Chile using non-conventional renewable energy sources-A focus on biomass. Renew. Sustain. Energy Rev. 2018, 81, 937-945. [CrossRef] 
18. Towards Pakistan's Energy Security and Competitiveness ... . Available online: https://www.pbc.org. pk/wp-content/uploads/Towards-Pakistanu2019s-Energy-Security-and-Competitiveness.pdf (accessed on 18 August 2018).

19. Wakeel, M.; Chen, B.; Jahangir, S. Overview of Energy Portfolio in Pakistan. Energy Procedia 2016, 88, 71-75. [CrossRef]

20. World Energy Resources Bioenergy. Available online: https://www.worldenergy.org/wp-content/uploads / 2017/03/WEResources_Bioenergy_2016.pdf (accessed on 18 August 2018).

21. State of Industry Report 2016. National Electric Power Regulatory Authority: Pakistan, 2016. Available online: https:/ / www.nepra.org.pk/industryreports.htm (accessed on 18 August 2018).

22. Ozturk, M.; Saba, N.; Altay, V.; Iqbal, R.; Hakeem, K.R.; Jawaid, M. Biomass and bioenergy: An overview of the development potential in Turkey and Malaysia. Renew. Sustain. Energy Rev. 2017, 79, 1285-1302. [CrossRef]

23. Main-Knorn, M.; Cohen, W.B.; Kennedy, R.E.; Grodzki, W.; Pflugmacher, D.; Griffiths, P. Monitoring coniferous forest biomass change using a Landsat trajectory-based approach. Remote. Sens. Environ. 2013, 139, 277-290. [CrossRef]

24. Nansaior, A.; Patanothai, A.; Rambo, A.T.; Simaraks, S. The sustainability of biomass energy acquisition by households in urbanizing communities in Northeast Thailand. Biomass Bioenergy 2013, 52, 113-121. [CrossRef]

25. Demirbaş, A. Biomass resource facilities and biomass conversion processing for fuels and chemicals. Energy Convers. Manag. 2001, 42, 1357-1378. [CrossRef]

26. McKendry, P. Energy production from biomass (part 2): Conversion technologies. Bioresour. Technol. 2002, 83, 47-54. [CrossRef]

27. Do We Need More Nuclear Power? Available online: https://www.renewableenergyworld.com/ugc/articles/ 2015/04/renewables-vs-nuclear-do-we-need-more-nuclear-power.html (accessed on 18 August 2018).

28. Thiffault, E.; Endres, J.; McCubbins, J.S.; Junginger, M.; Lorente, M.; Fritsche, U. Sustainability of forest bioenergy feedstock supply chains: Local, national and international policy perspectives. Biofuels Bioprod. Biorefin. 2015, 9, 283-292. [CrossRef]

29. Li, Y.; Zhou, L.W.; Wang, R.Z. Urban biomass and methods of estimating municipal biomass resources. Renew. Sustain. Energy Rev. 2017, 80, 1017-1030. [CrossRef]

30. Goldemberg, J. World Energy Assessment: Energy and the Challenge of Sustainability. Available online: https://books.google.com.pk/books?id=7V3xAAAAMAAJ (accessed on 18 August 2018).

31. Bhattacharya, S. Biomass Energy and Densification: A Global Review with Emphasis on Developing Countries. Available online: http:/ / citeseerx.ist.psu.edu/viewdoc/download?doi=10.1.1.630.4397\&rep= rep1\&type $=$ pdf (accessed on 18 August 2018).

32. Hughes, E.E.; Tillman, D. A Biomass Cofiring: Status and prospects 1996. Fuel Proc. Technol. 1998, 54, 127-142. [CrossRef]

33. Sami, M.; Annamalai, K.; Wooldridge, M. Co-firing of coal and biomass fuel blends. Prog. Energy Combust. Sci. 2001, 27, 171-214. [CrossRef]

34. Jingura, R.M.; Musademba, D.; Kamusoko, R. A review of the state of biomass energy technologies in Zimbabwe. Renew. Sustain. Energy Rev. 2013, 26, 652-659. [CrossRef]

35. Bloyd, C.N.; Streets, D.G.; Fisher, R.E. Energy models and national energy policy. In Proceedings of the 25th Intersociety, Reno, NV, USA, 12-17 August 1990; pp. 244-249.

36. Shukla, S.K.; Gupta, R.K. A model checking approach to evaluating system level dynamic power management policies for embedded systems. In Proceedings of the Sixth IEEE International High-Level Design Validation and Test Workshop, Monterey, CA, USA, 9 November 2001; pp. 53-57.

37. Munasinghe, M. Power policy and environmental issues in developing countries. Power Eng. J. 1992, 6, 171-178. [CrossRef]

38. Tao, Y.; Xue, H.F.; Huang, L. The Sustainable Energy Tax Policy Decision-Making Model Based on Invest Willingness Constraint. In Proceedings of the 2009 WRI World Congress on Computer Science and Information Engineering, Los Angeles, CA, USA, 31 March-2 April 2009; pp. 307-311.

39. Framework, P. Package of Incentives for Private Sector Power Generation Projects in Pakistan. Available online: http:/ / www.ppib.gov.pk/Power\%20Policy\%201994.pdf (accessed on 18 August 2018). 
40. Policy for Development of Renewable Energy for Power Generation Employing Small Hydro, Wind, and Solar Technologies. Available online: https:/ / www.aedb.org/Documents/Policy/REpolicy.pdf (accessed on 18 August 2018).

41. Li, Y.; Li, Y.; Ji, P.; Yang, J. The status quo analysis and policy suggestions on promoting China's hydropower development. Renew. Sustain. Energy Rev. 2015, 51, 1071-1079. [CrossRef]

42. Liu, B.; Liao, S.; Cheng, C.; Chen, F.; Li, W. Hydropower curtailment in Yunnan Province, southwestern China: Constraint analysis and suggestions. Renew. Energy 2018, 121, 700-711. [CrossRef]

43. Koç, C. A study on the development of hydropower potential in Turkey. Renew. Sustain. Energy Rev. 2014, 39, 498-508. [CrossRef]

44. Chang, J.; Li, Y.; Yuan, M.; Wang, Y. Efficiency evaluation of hydropower station operation: A case study of Longyangxia station in the Yellow River, China. Energy 2017, 135, 23-31. [CrossRef]

45. Bilgili, M.; Bilirgen, H.; Ozbek, A.; Ekinci, F.; Demirdelen, T. The role of hydropower installations for sustainable energy development in Turkey and the world. Renew. Energy 2018, 126, 755-764. [CrossRef]

46. Cheng, C.-T.; Shen, J.-J.; Wu, X.-Y.; Chau, K.-W. Operation challenges for fast-growing China's hydropower systems and respondence to energy saving and emission reduction. Renew. Sustain. Energy Rev. 2012, 16, 2386-2393. [CrossRef]

47. Power System Statistics 2013-2014. Available online: http:/ / climateinfo.pk/frontend/web /attachments / data-type/NTDC\%20(2014)\%20Power\%20System\%20Statistics.pdf (accessed on 18 August 2018).

48. Shakeel, S.R.; Takala, J.; Shakeel, W. Renewable energy sources in power generation in Pakistan. Renew. Sustain. Energy Rev. 2016, 64, 421-434. [CrossRef]

49. Power System Statistics 2015-2016. Available online: www.kseb.in/index.php?option=com_jdownloads\& task=download...id (accessed on 18 August 2018).

50. Imran, M.; Amir, N. A short-run solution to the power crisis of Pakistan. Energy Policy 2015, 87, $382-391$. [CrossRef]

51. Saleemullah, M. Comparison of electricity generation cost of NPP with alternatives in Pakistan. In Proceedings of the International Atomic Energy Agency IAEA, International Project on Innovative Nuclear Reactors and Fuel Cycles INPRO, Vienna, Austria, 26-29 August 2014.

52. Sabir, M.; Torre, A.; Magsi, H. Land-use conflict and socio-economic impacts of infrastructure projects: The case of Diamer Bhasha Dam in Pakistan. Area Dev. Policy 2017, 2, 40-54. [CrossRef]

53. Construction of Kalabagh Dam-Background Paper. Available online: http://admin.umt.edu.pk/Media/Site/ UMT/SubSites/SGS/FileManager/Research/ConstructionOfKalabaghDamBackgroundPaper.pdf (accessed on 18 August 2018).

54. Bhutto, A.W.; Bazmi, A.A.; Zahedi, G. Greener energy: Issues and challenges for Pakistan-hydel power prospective. Renew. Sustain. Energy Rev 2012, 16, 2732-2746. [CrossRef]

55. Siddiqi, A.; Wescoat, J.L.; Humair, S.; Afridi, K. An empirical analysis of the hydropower portfolio in Pakistan. Energy Policy 2012, 50, 228-241. [CrossRef]

56. Asif, M. Sustainable energy options for Pakistan. Renew. Sustain. Energy Rev. 2009, 13, 903-909. [CrossRef]

57. Qazi, U.; Jahanzaib, M.; Ahmad, W.; Hussain, S. An institutional framework for the development of sustainable and competitive power market in Pakistan. Renew. Sustain. Energy Rev. 2017, 70, 83-95. [CrossRef]

58. Mirjat, N.H.; Uqaili, M.A.; Harijan, K.; Valasai, G.D.; Shaikh, F.; Waris, M. A review of energy and power planning and policies of Pakistan. Renew. Sustain. Energy Rev. 2017, 79, 110-127. [CrossRef]

59. Bhutto, A.W.; Bazmi, A.A.; Zahedi, G. Greener energy: Issues and challenges for Pakistan-Wind power prospective. Renew. Sustain. Energy Rev 2013, 20, 519-538. [CrossRef]

60. Zameer, H.; Wang, Y. Energy production system optimization: Evidence from Pakistan. Renew. Sustain. Energy Rev. 2018, 82, 886-893. [CrossRef]

61. Batool, A.; Abbas, F. Reasons for delay in selected hydro-power projects in Khyber Pakhtunkhwa (KPK), Pakistan. Renew. Sustain. Energy Rev. 2017, 73, 196-204. [CrossRef]

62. Prăvălie, R.; Bandoc, G. Nuclear energy: Between global electricity demand, worldwide decarbonisation imperativeness, and planetary environmental implications. J. Environ. Manag. 2018, 209, 81-92. [CrossRef] [PubMed]

63. Suman, S. Hybrid nuclear-renewable energy systems: A review. J. Clean. Prod. 2018, 181, 166-177. [CrossRef] 
64. Birol, F. Energy Security: Investment or Insecurity. Available online: https:/ /www.ipinst.org/wp-content/ uploads/2015/06/cwc_working_paper_energy_security.pdf (accessed on 18 August 2018).

65. Demirbas, A. Global Renewable Energy Projections. Energy Sources Part. B 2009, 4, 212-224. [CrossRef]

66. Aized, T.; Shahid, M.; Bhatti, A.A.; Saleem, M.; Anandarajah, G. Energy security and renewable energy policy analysis of Pakistan. Renew. Sustain. Energy Rev 2018, 84, 155-169. [CrossRef]

67. Akhtar, J.; Yaqub, M.I.; Iqbal, J.; Sheikh, N.; Saba, T. Way forward in meeting energy challenges in Pakistan. Int. J. Ambient. Energy 2017, 1-5. [CrossRef]

68. Akber, M.Z.; Thaheem, M.J.; Arshad, H. Life cycle sustainability assessment of electricity generation in Pakistan: Policy regime for a sustainable energy mix. Energy Policy 2017, 111, 111-126. [CrossRef]

69. Shaikh, F.; Ji, Q.; Fan, Y. The diagnosis of an electricity crisis and alternative energy development in Pakistan. Renew. Sustain. Energy Rev. 2015, 52, 1172-1185. [CrossRef]

70. Global Wind Report: Annual Market Update 2011. Available online: http:/ /gwec.net/wp-content/uploads / 2012/06/Annual_report_2011_lowres.pdf (accessed on 18 August 2018).

71. Tareen, W.; Aamir, M.; Mekhilef, S.; Nakaoka, M.; Seyedmahmoudian, M.; Horan, B.; Memon, M.A.; Baig, N.A. Mitigation of Power Quality Issues Due to High Penetration of Renewable Energy Sources in Electric Grid Systems Using Three-Phase APF/STATCOM Technologies: A Review. Energies 2018, 11, 1491. [CrossRef]

72. World Energy Outlook 2008. Available online: https://www.iea.org/media/weowebsite/2008-1994/ WEO2008.pdf (accessed on 18 August 2018).

73. World Energy Outlook 2009. Available online: https://www.iea.org/publications/freepublications/ publication/weo2009.pdf (accessed on 18 August 2018).

74. Pure Power-Wind Energy Targets for 2020 and 2030: EWEA. Available online: https:/ /books.google.com. hk/books?hl=zhTW\&lr=\&id=cXuSk8jvHykC\&oi=fnd\&pg=PA8\&dq=Pure+powerwind +energy+targets + for+2020+and+2030:+EWEA.+\&ots=HHw8bB4_TU\&sig=uw_w7jFUbA1tPSUjTmU9mJ2uOFE\&redir_ esc $=\mathrm{y} \# \mathrm{v}=$ onepage \&q=Pure $\% 20$ powerwind $\% 20$ energy $\% 20$ targets $\% 20$ for $\% 202020 \% 20 \mathrm{and} \% 202030 \% 3 \mathrm{~A} \%$ 20EWEA.\&f=false (accessed on 18 August 2018).

75. Global Wind 2008 Report. Available online: http://gwec.net/wp-content/uploads/2012/06/Global-Wind2008-Report.pdf (accessed on 18 August 2018).

76. Global Wind Energy Outlook 2008. Available online: http://gwec.net/wp-content/uploads/2012/08/ GWEO_2008_final.pdf (accessed on 18 August 2018).

77. Baloch, M.H.; Abro, S.A.; Sarwar Kaloi, G.; Mirjat, N.H.; Tahir, S.; Haroon Nadeem, M.; Gul, M.; Memon, Z.A.; Kumar, M. A research on electricity generation from wind corridors of Pakistan (two provinces): A technical proposal for remote zones. Sustainability 2017, 9, 1611. [CrossRef]

78. Siddique, S.; Wazir, R. A review of the wind power developments in Pakistan. Renew. Sustain. Energy Rev. 2016, 57, 351-361. [CrossRef]

79. Mouraviev, N.; Kakabadse, N. Public-Private Partnerships in Transitional Nations: Policy, Governance and Praxis; Cambridge Scholars Publishing: Newcastle, UK, 2017.

80. Annual Report 2014. National Electric Power Regulatory Authority: Pakistan, 2014. Available online: https: / / www.nepra.org.pk/Publications / Annual\%20Reports / Annual\%20report\%202016-2017.pdf (accessed on 18 August 2018).

81. Global Wind Energy Outlook 2014. Available online: https://www.gwec.net/wp-content/uploads/2014/ 10/GWEO2014_WEB.pdf (accessed on 18 August 2018).

82. Sadiqa, A.; Gulagi, A.; Breyer, C. Energy transition roadmap towards $100 \%$ renewable energy and role of storage technologies for Pakistan by 2050. Energy 2018, 147, 518-533. [CrossRef]

83. Ghafoor, A.; Munir, A. Design and economics analysis of an off-grid PV system for household electrification. Renew. Sustain. Energy Rev. 2015, 42, 496-502. [CrossRef]

84. Tahir, Z.R.; Asim, M. Surface measured solar radiation data and solar energy resource assessment of Pakistan: A review. Renew. Sustain. Energy Rev. 2018, 81, 2839-2861. [CrossRef]

85. Sheikh, M.A. Energy and renewable energy scenario of Pakistan. Renew. Sustain. Energy Rev. 2010, 14, 354-363. [CrossRef]

86. Irfan, M.; Iqbal, J.; Iqbal, A.; Iqbal, Z.; Riaz, R.A.; Mehmood, A. Opportunities and challenges in control of smart grids-Pakistani perspective. Renew. Sustain. Energy Rev. 2017, 71, 652-674. [CrossRef] 
87. Zafar, U.; Ur Rashid, T.; Khosa, A.A.; Khalil, M.S.; Rashid, M. An overview of implemented renewable energy policy of Pakistan. Renew. Sustain. Energy Rev. 2018, 82, 654-665. [CrossRef]

88. Sandeman, J. Feed-In Tariffs: Accelerating the Deployment of Renewable Energy. Int. J. Environ. Stud. 2010, 67, 463. [CrossRef]

89. Younas, U.; Khan, B.; Ali, S.M.; Arshad, C.M.; Farid, U.; Zeb, K.; Rehman, F.; Mehmood, Y.; Vaccaro, A. Pakistan geothermal renewable energy potential for electric power generation: A survey. Renew. Sustain. Energy Rev. 2016, 63, 398-413. [CrossRef]

90. Alam Zaigham, N.; Alam Nayyar, Z.; Hisamuddin, N. Review of geothermal energy resources in Pakistan. Renew. Sustain. Energy Rev. 2009, 13, 223-232. [CrossRef]

91. Geotherm. Resources of Pakistan and Methods for Early Stage Exploration. Available online: https: / / orkustofnun.is/gogn/unu-gtp-report/UNU-GTP-1998-09.pdf (accessed on 18 August 2018).

92. Abbas, T.; Ahmed Bazmi, A.; Waheed Bhutto, A.; Zahedi, G. Greener energy: Issues and challenges for Pakistan-geothermal energy prospective. Renew. Sustain. Energy Rev. 2014, 31, 258-269. [CrossRef]

93. Gondal, I.A.; Masood, S.A.; Amjad, M. Review of geothermal energy development efforts in Pakistan and way forward. Renew. Sustain. Energy Rev. 2017, 71, 687-696. [CrossRef]

94. Lund, J.W.; Boyd, T.L. Direct utilization of geothermal energy 2015 worldwide review. Geothermics 2016, 60, 66-93. [CrossRef]

95. Zaigham, N.A.; Nayyar, Z.A. Renewable hot dry rock geothermal energy source and its potential in Pakistan. Renew. Sustain. Energy Rev. 2010, 14, 1124-1129. [CrossRef]

96. Mahmood, A.; Javaid, N.; Zafar, A.; Ali Riaz, R.; Ahmed, S.; Razzaq, S. Pakistan's overall energy potential assessment, comparison of LNG, TAPI and IPI gas projects. Renew. Sustain. Energy Rev. 2014, 31, 182-193. [CrossRef]

97. Mirza, U.K.; Ahmad, N.; Majeed, T. An overview of biomass energy utilization in Pakistan. Renew. Sustain. Energy Rev. 2008, 12, 1988-1996. [CrossRef]

98. Ud Din, Z.; Zainal, Z.A. Biomass integrated gasification-SOFC systems: Technology overview. Renew. Sustain. Energy Rev. 2016, 53, 1356-1376. [CrossRef]

99. Kan, T.; Strezov, V.; Evans, T.J. Lignocellulosic biomass pyrolysis: A review of product properties and effects of pyrolysis parameters. Renew. Sustain. Energy Rev. 2016, 57, 1126-1140. [CrossRef]

100. Gondal, I.A.; Masood, S.A.; Khan, R. Green hydrogen production potential for developing a hydrogen economy in Pakistan. Int. J. Hydrogen Energy 2018, 43, 6011-6039. [CrossRef]

101. Naqvi, S.R.; Jamshaid, S.; Naqvi, M.; Farooq, W.; Niazi, M.B.K.; Aman, Z.; Zubair, M.; Ali, M.; Shahbaz, M.; Inayat, A.; et al. Potential of biomass for bioenergy in Pakistan based on present case and future perspectives. Renew. Sustain. Energy Rev. 2018, 81, 1247-1258. [CrossRef]

102. Ben-Iwo, J.; Manovic, V.; Longhurst, P. Biomass resources and biofuels potential for the production of transportation fuels in Nigeria. Renew. Sustain. Energy Rev. 2016, 63, 172-192. [CrossRef]

103. Toklu, E. Biomass energy potential and utilization in Turkey. Renew. Energy 2017, 107, 235-244. [CrossRef]

104. Zhao, X.; Cai, Q.; Li, S.; Ma, C. Public preferences for biomass electricity in China. Renew. Sustain. Energy Rev. 2018, 95, 242-253. [CrossRef]

105. He, J.; Liu, Y.; Lin, B. Should China support the development of biomass power generation? Energy 2018, 163, 416-425. [CrossRef]

106. Mosaddek Hossen, M.; Sazedur Rahman, A.H.M.; Kabir, A.S.; Faruque Hasan, M.M.; Ahmed, S. Systematic assessment of the availability and utilization potential of biomass in Bangladesh. Renew. Sustain. Energy Rev. 2017, 67, 94-105. [CrossRef]

107. World Energy Council. World Energy Council Report. World Energy Resources Bioenergy, 2017. Available online: https:/ / www.worldenergy.org/wp-content/uploads/2017/03/WEResources_Bioenergy_2017.pdf (accessed on 18 August 2018).

108. Al-Hamamre, Z.; Saidan, M.; Hararah, M.; Rawajfeh, K.; Alkhasawneh, H.E.; Al-Shannag, M. Wastes and biomass materials as sustainable-renewable energy resources for Jordan. Renew. Sustain. Energy Rev. 2017, 67, 295-314. [CrossRef]

109. Uzoejinwa, B.B.; He, X.; Wang, S.; El-Fatah Abomohra, A.; Hu, Y.; Wang, Q. Co-pyrolysis of biomass and waste plastics as a thermochemical conversion technology for high-grade biofuel production: Recent progress and future directions elsewhere worldwide. Energy Convers. Manag. 2018, 163, 468-492. [CrossRef] 
110. Hofsetz, K.; Silva, M.A. Brazilian sugarcane bagasse: Energy and non-energy consumption. Biomass Bioenergy 2012, 46, 564-573. [CrossRef]

111. Wi, S.G.; Cho, E.J.; Lee, D.-S.; Lee, S.J.; Lee, Y.J.; Bae, H.-J. Lignocellulose conversion for biofuel: A new pretreatment greatly improves downstream biocatalytic hydrolysis of various lignocellulosic materials. Biotechnol. Biofuels 2015, 8, 228. [CrossRef] [PubMed]

112. Abedullah, A.; Bukhsh, K. Issues and economics of poultry production: A case study of Faisalabad, Pakistan. Pak. Vet. J. 2007, 27, 25-28.

113. Lisboa, C.C.; Butterbach-Bahl, K.; Mauder, M.; Kiese, R. Bioethanol production from sugarcane and emissions of greenhouse gases-Known and unknowns. GCB Bioenergy 2011, 3, 277-292. [CrossRef]

114. Bhattacharyya, S.C.; Thang, D.N.Q. The cogeneration potential of the sugar industry in Vietnam. OPEC Energy Rev. 2004, 28, 63-80. [CrossRef]

115. Anwar, Z.; Gulfraz, M.; Irshad, M. Agro-industrial lignocellulosic biomass a key to unlock the future bio-energy: A brief review. J. Radiat. Res. Appl. Sci. 2014, 7, 163-173. [CrossRef]

116. Paturau, J.M. Alternative Uses of Sugarcane and Its Byproducts in Agroindustries. Available online: http:/ / www.fao.org/livestock/agaP/Frg/AHPP72/72-24.pdf (accessed on 18 August 2018).

117. SRDC Technical Report 2/2006: Analysis of Bagase and Trash Utilization Options. Available online: https:/ / elibrary.sugarresearch.com.au/bitstream/handle/11079/13234/SRD005\%20SRDC\%20BagTrash\% 20RptF.pdf? sequence=1\&isAllowed=y (accessed on 18 August 2018).

118. Saeed, A. Prospects of Bagasse as a feasible bio-fuel for electricity generation in Pakistan-A realistic approach. In Proceedings of the 2015 Power Generation System and Renewable Energy Technologies (PGSRET), Islamabad, Pakistan, 10-11 June 2015; pp. 1-4.

119. Frame Work for Power Co-Generation 2013 (Bagasse/Biomass). Available online: http://www.aedb.org/aepolicies/policy-bioenergy (accessed on 18 August 2018).

120. HIGHLIGHTS OF THE PAKISTAN ECONOMIC SURVEY 2012-13. Available online: http:/ / finance.gov.pk/ survey/chapters_13/hghlights\%202013.pdf (accessed on 18 August 2018).

121. Hussain, J.; Rabbani, I.; Aslam, S.; Ahmad, H.A. An overview of poultry industry in Pakistan. World's Poult. Sci. J. 2015, 71, 689-700. [CrossRef] [PubMed]

122. Reducing Capital Cost and Providing Electricity to Grid by Power Generation from Poultry Farms. Available online: https:/ / pdfs.semanticscholar.org/681c/1325f56ce45d736aa1f01c6e5ac6060df5cd.pdf (accessed on 18 August 2018).

123. Salminen, E.; Rintala, J. Anaerobic digestion of organic solid poultry slaughterhouse waste-A review. Bioresour. Technol. 2002, 83, 13-26. [CrossRef]

124. Mandeno, G.; Craggs, R.; Tanner, C.; Sukias, J.; Webster-Brown, J. Potential biogas scrubbing using a high rate pond. Water Sci. Technol. 2005, 51, 253-256. [CrossRef] [PubMed]

125. Biomethane from Dairy Waste. Available online: http://www.americanbiogascouncil.org/pdf/ biomethanefromdairywaste.pdf (accessed on 18 August 2018).

126. Eldean, M.A.S.; Soliman, A. A novel study of using oil refinery plants waste gases for thermal desalination and electric power generation: Energy, exergy \& cost evaluations. Appl. Energy 2017, 195, 453-477.

127. Wang, K.; Dubey, S.; Choo, F.H.; Duan, F. Thermoacoustic Stirling power generation from LNG cold energy and low-temperature waste heat. Energy 2017, 127, 280-290. [CrossRef]

128. León, E.; Martín, M. Optimal production of power in a combined cycle from manure based biogas. Energy Convers. Manag. 2016, 114, 89-99. [CrossRef]

129. Uddin, W.; Khan, B.; Shaukat, N.; Majid, M.; Mujtaba, G.; Mehmood, A.; Ali, S.M.; Younas, U.; Anwar, M.; Almeshal, A.M. Biogas potential for electric power generation in Pakistan: A survey. Renew. Sustain. Energy Rev. 2016, 54, 25-33. [CrossRef]

130. Ferrarez, A.H.; Oliveira, D.; Lacerda, A.F.; Costa, J.M.; Aparisi, F.S. Supplying the energy demand in the chicken meat processing poultry with biogas. Ingeniería e Investigación 2016, 36, 118-121. [CrossRef]

131. Anaerobic Digestion of Animal Wastes: Factors to Consider. Available online: https://attra.ncat.org/attrapub/download.php?id=307 (accessed on 18 August 2018).

132. Arshad, M.; Bano, I.; Khan, N.; Shahzad, M.I.; Younus, M.; Abbas, M.; Iqbal, M. Electricity generation from biogas of poultry waste: An assessment of potential and feasibility in Pakistan. Renew. Sustain. Energy Rev. 2018, 81, 1241-1246. [CrossRef] 
133. Jouhara, H.; Czajczyńska, D.; Ghazal, H.; Krzyżyńska, R.; Anguilano, L.; Reynolds, A.J.; Spencer, N. Municipal waste management systems for domestic use. Energy 2017, 139, 485-506. [CrossRef]

134. Sandulescu, E. The contribution of waste management to the reduction of greenhouse gas emissions with applications in the city of Bucharest. Waste Manag. Res. 2004, 22, 413-426. [CrossRef] [PubMed]

135. Solid Waste Management: Issues and Challenges in Asia. Available online: http://www.apo-tokyo.org/00ebooks/IS-22_SolidWasteMgt/IS-22_SolidWasteMgt.pdf (accessed on 18 August 2018).

136. Misra, V.; Pandey, S.D. Hazardous waste, impact on health and environment for development of better waste management strategies in future in India. Environ. Int. 2005, 31, 417-431. [CrossRef] [PubMed]

137. Grodzińska-Jurczak, M. The relation between education, knowledge and action for better waste management in Poland. Waste Manag. Res. 2003, 21, 2-18. [CrossRef] [PubMed]

138. Woodard, R.; Bench, M.; Harder, M.K.; Stantzos, N. The optimisation of household waste recycling centres for increased recycling-A case study in Sussex, UK. Resour. Conserv. Recycl. 2004, 43, 75-93. [CrossRef]

139. Lariviere, M. Methodology for Allocating Municipal Solid Waste to Biogenic and Non-Biogenic Energy. 2007. Available online: http:/ / www.eia.doe.gov/cneaf/solar.renewables/page/mswaste/msw.pdf (accessed on 18 August 2018).

140. ADB's Clean Energy and Environment Program, Asian Development Bank. November 2007. Available online: https://unfccc.int/files/adaptation/sbsta_agenda_item_adaptation/application/pdf/ adb_ccadaptation.pdf (accessed on 18 August 2018).

141. Korai, M.S.; Mahar, R.B.; Uqaili, M.A. The feasibility of municipal solid waste for energy generation and its existing management practices in Pakistan. Renew. Sustain. Energy Rev. 2017, 72, 338-353. [CrossRef]

142. Zuberi, M.J.S.; Torkmahalleh, M.A.; Ali, S.M.H. A comparative study of biomass resources utilization for power generation and transportation in Pakistan. Int. J. Hydrogen Energy 2015, 40, 11154-11160. [CrossRef]

143. Ashraf Chaudhry, M.; Raza, R.; Hayat, S.A. Renewable energy technologies in Pakistan: Prospects and challenges. Renew. Sustain. Energy Rev. 2009, 13, 1657-1662. [CrossRef]

144. SUGAR INDUSTRY IN PAKISTAN Problems, Potentials. Available online: https://www.icmap.com.pk/ downloads/Past-Publications/sipp_\%20potentials.pdf (accessed on 18 August 2018).

145. A Review of North American Biofuel Production, Policies and Research. Available online: https:/ / www.researchgate.net/profile/Michael_Martin10/publication/293794254_A_review_of_ North_American_Biofuel_Production_Policies_and_Research/links/56bb30a708aebb3054a85f69/Areview-of-North-American-Biofuel-Production-Policies-and-Research.pdf (accessed on 18 August 2018).

146. Scarlat, N.; Dallemand, J.-F.; Fahl, F. Biogas: Developments and perspectives in Europe. Renew. Energy 2018, 129, 457-472. [CrossRef]

147. Khan, M.I. Comparative Well-to-Tank energy use and greenhouse gas assessment of natural gas as a transportation fuel in Pakistan. Energy Sustain. Dev. 2018, 43, 38-59. [CrossRef]

148. How Pakistan Is Coping with the Challenge of High Oil Prices. Available online: https://mpra.ub.unimuenchen.de/8256/1/MPRA_paper_8256.pdf (accessed on 18 August 2018).

149. Wileman, A.; Ozkan, A.; Berberoglu, H. Rheological properties of algae slurries for minimizing harvesting energy requirements in biofuel production. Bioresour. Technol. 2012, 104, 432-439. [CrossRef] [PubMed]

150. Tareen, W.U.K.; Mekhielf, S. Three-Phase Transformerless Shunt Active Power Filter with Reduced Switch Count for Harmonic Compensation in Grid-Connected Applications. IEEE Trans. Power Electron. 2018, 33, 4868-4881. [CrossRef]

151. Tareen, W.U.; Mekhilef, S.; Seyedmahmoudian, M.; Horan, B. Active power filter (APF) for mitigation of power quality issues in grid integration of wind and photovoltaic energy conversion system. Renew. Sustain. Energy Rev. 2017, 70, 635-655. [CrossRef]

152. Tareen, W.U.K.; Mekhilef, S.; Nakaoka, M. A transformerless reduced switch counts three-phase APF-assisted smart EV charger. In Proceedings of the 2017 IEEE Applied Power Electronics Conference and Exposition (APEC), Tampa, FL, USA, 26-30 March 2017. Available online: https://umexpert.um.edu.my/file/ publication/00005361_151743_71512.pdf (accessed on 18 August 2018).

(C) 2018 by the authors. Licensee MDPI, Basel, Switzerland. This article is an open access article distributed under the terms and conditions of the Creative Commons Attribution (CC BY) license (http:/ / creativecommons.org/licenses/by/4.0/). 